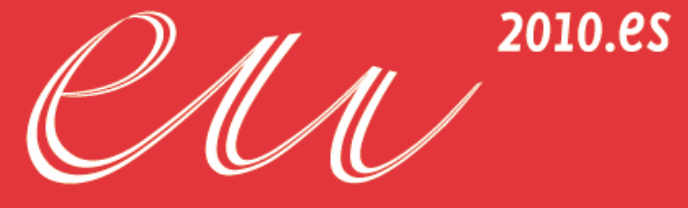

Presidencia Española de la Uniön Europea CONFERENCE ON

\title{
DEVELOPMENT COOPERATION
}

IN TIMES OF CRISIS AND ON ACHIEVING THE MDGs

IFEMA Convention Centre (Madrid)

9-10 June 2010

\section{The great recession and the developing world}

José Antonio Ocampo, Stephany Griffith-Jones, Akbar Noman, Ariane Ortiz, Juliana Vallejo and Judith Tyson 


\section{Contents}

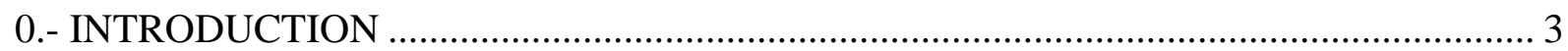

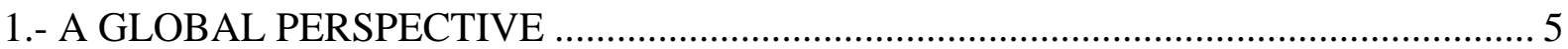

2.- CHANNELS OF TRANSMISSION OF THE CRISIS ................................................. 11

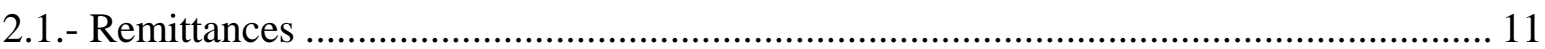

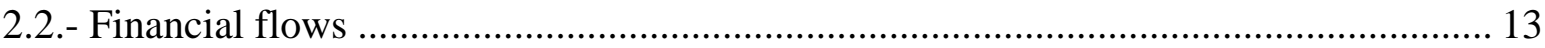

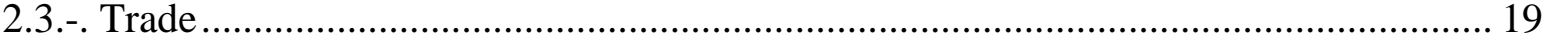

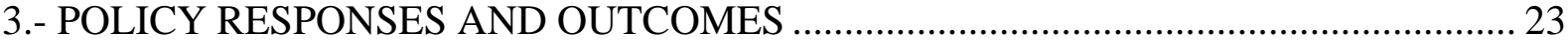

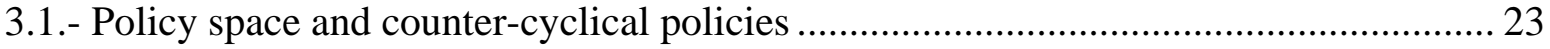

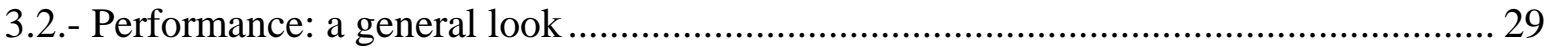

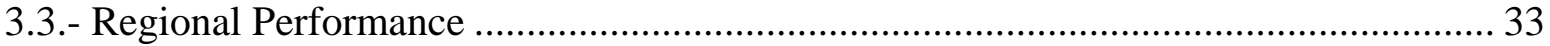

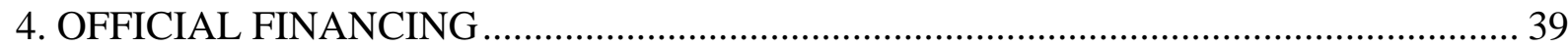

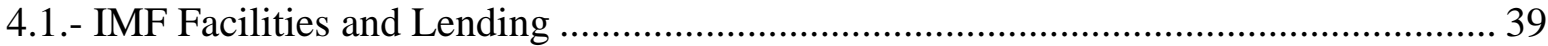

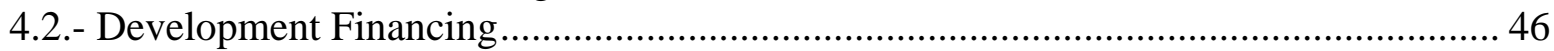

5.- CONCLUSIONS AND GLOBAL POLICY IMPLICATIONS …..................................... 55

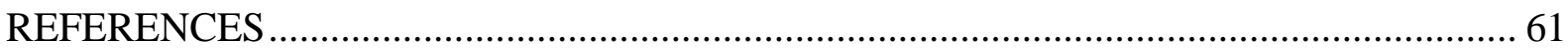




\section{0.- Introduction}

In 2003-2007, the developing world experienced a pattern of rapid and broad-based economic growth at a rate of over 7\% per year, much faster than in the industrial world, which grew at a rate of $2.7 \%$ during these years. Phases of "catching-up" (or convergence) with the industrial world such as this have been rare through history, which has rather been plagued by a divergence in the growth of the developing vs. the industrial world, the pattern that was typical through the "lost decade" of the 1980s in many parts of the developing world as well as through 1990s and the early years of the twentieth century. The worst situation was, of course, that of Sub-Saharan Africa, which experienced not a lost decade but a "lost quarter century”. Latin America also lost a quarter century in terms of poverty reduction, as according to the estimates of the UN Economic Commission for Latin America and the Caribbean (ECLAC), income poverty only returned in 2004 to the levels of 1980. Of course, the experience of the 1980s and 1990s had been very positive in several developing countries, particularly of Asia and even more specifically its two giants, China and India, thus configuring what Ocampo and Parra (2007) termed a "dual divergence" -both between the industrial and the developing world, and among developing countries.

In light of past experience, the expectation that the UN Millennium Development Goals (MDGs) would not be achieved in many of the parts of the developing world was widespread in the early part of the century. At the end of the boom, perceptions had changed, and it seemed that it was indeed possible to achieve them in many developing countries and regions. The recovery of official development assistance (ODA) after the UN Conference on Financing for Development held at Monterrey in 2002 was a source of additional hope.

The 2003-2007 boom was fueled by an exceptional mix of circumstances benefiting the developing world: exceptional financing, in terms of both cost and quantities; booming international trade, including high commodity prices; and, for a significant number of developing countries, also large flows of remittances. The mix of good financial conditions and high commodity prices had been experienced for the last time in the 1970s, while the mix of these two factors with remittances had never been experienced before. The rise of an alternative Asian engine, with China at the center, was an additional element, which has had a strong influence on world trade and commodity prices, as well, in the case of Sub-Saharan Africa, on development financing and foreign investment.

These conditions were replaced since mid-2007 by the effects of the subprime financial crisis that erupted in August 2007 in the US and soon also affected Western Europe. However, for a year after the crisis erupted, commodity prices continued to boom. This factor, together with high foreign exchange reserves, helped to attract capital to emerging markets even under the growing world financial uncertainty. In mid-2008 commodity prices started to fall and financing to dry out. The real blow came, however, with the US financial meltdown of midSeptember 2008, which precipitated the worst world financial crisis since the Great Depression, one of the worst (if not the worst) collapses of international trade in history and the worst world recession since the 1930s -now widely branded as the "Great Recession". Developing countries now clearly joined the downturn. The view espoused by the IMF and 
some other analysts in 2007 that the developing world would "decouple" from weak economic conditions in industrial countries turned out to be essentially a mirage.

The strong counter-cyclical policies that were put in place in the industrial world and several developing countries, notably China, helped avoid another Great Depression. Recovery started in the second quarter of 2009, though following a pattern that the IMF (2010a) has termed “a policy-driven, multispeed recovery”. Financial and commodity prices also recovered, although incompletely, and the pattern of world economic growth generated threats of new world payments imbalances. Despite the recovery, even in late 2009, trade continued significantly below pre-crisis levels, and the same is true of the flow of remittances from migrants living in the US, Western Europe and Russia, though not in the Middle East, which remained resilient. Overall, the experience of the developing countries was very diverse and had some novelties, thanks to the strengths they built up during the boom and the rapid return of Chinese engine of world growth.

This essay analyzes the effects of the crisis in the developing world, which in the definition that we used encompasses what in the literature are called "emerging economies" (a concept that lacks a clear definition ${ }^{1}$ ) and encompasses the so called "transition economies" of Central and Eastern Europe (including those that are now members of the European Union) as well as Central Asia. It is divided in five parts. The first briefly looks at the nature and phases of the crisis as seen from a global perspective. The second analyzes all the channels of transmission to the developing world. The third considers the performance of developing countries. The fourth considers the policy responses by the international community. The last draws some policy conclusions.

It must be pointed out that we mix throughout the paper United Nations as well as IMF (sometimes also World Bank) data. This presents some problems, as these two institutions use different regional breakdowns, and they also had as of early 2010 very diverse estimates of growth in individual economies. Although UN regional classifications are better to analyze trends in the developing world, financial data is only available from the IMF (and, again, World Bank) with a different breakdown. In turn, private data, such as that from the Institute of International Finance (IIF) is only available for the emerging economies. To make things more complicated, the ILO uses still a third regional breakdown in its analysis of employment trends. So, in our analysis we mix different sources. In the case of aggregate GDP statistics, we clearly prefer, for technical reasons, UN data. ${ }^{2}$

\footnotetext{
${ }^{1}$ One definition, which is implicit in the recent book by Reinhart and Rogoff (2009), is the countries that have access to private capital markets, which would generally be middle-income countries.

${ }^{2}$ This is due to the peculiar methodology used by the IMF, which adds up GDPs estimated using purchasing power (PPP) rather than market prices and exchange rates, which makes the regional and, particularly, global data clearly imprecise. The most important bias introduced by the peculiar IMF methodology is that global GDP growth is consistently overestimated, due to the excessive weight given to the Chinese economy, which is much larger in PPP than in market price estimates. It also makes IMF GDP growth rates not comparable to other data; most notably trends in real trade variables cannot be compared with PPP GDP estimates. When using financial ratios, the IMF, as all analysts, in fact uses GDPs at market prices.
} 


\section{1.- A global perspective}

The peculiarity of the current crisis is, of course, that it originated at the center of the world economy. This is in striking contrast to the experience of both the industrial and the developing countries in previous decades. The first had experienced a "Great Moderation" i.e., an unusual period of smooth business cycles and stable inflation since the mid-1980s-, a term that the now Chairman of the US Federal Reserve Board (Bernanke, 2004) helped to popularize. In contrast, the developing world experienced during the same period what can be called a "Great Volatility", characterized by massive financial crises, which included the debt crisis of the 1980s in large parts of the developing world, the shorter 1994-95 crisis (sometimes called the Tequila crisis) and the worst and broadest based crisis, that which sparked in East Asia in mid-1997 and spread to Russia and Latin America and engulfed most of the developing world. Other crises occurred in individual countries (such as Brazil and Argentina). The assorted crises of the developing world typically had a common cause not only with each other but with the current crisis of the developed countries: excessive risktaking and exuberance in financial markets (Stiglitz, 2010).

The collapse of the market for asset-backed securities in the US in August 2007, in particular the market for subprime mortgages, can be denoted as the start of the world financial crisis. The European financial system was from the beginning at the center of the turmoil, and in fact the first major bankruptcies took place there at the end of 2007 (Northern Rock in the U.K. and IKB in Germany). This reflected the significant portfolio of US "toxic" securities held by European financial institutions, the end of their own housing bubbles and, soon after, serious financial turmoil in the European periphery (Iceland and several Central and Eastern European countries).

It is now broadly recognized that the major root of the crisis was the excessive confidence in the capacity of financial markets to self-regulate and self-correct in the face of major disturbances. This was reinforced by the regulatory deficit in finance, which was in fact most severe in industrial countries, which continued to deregulate their financial systems while many developing economies took steps to strengthen regulation after their own past financial crises. Equally important was the incapacity or unwillingness of authorities, through adequate supervision, to effectively enforce even those regulations that were in place.

The expansionary monetary policies of the first half of the 2000s are also widely accepted as a major contributor to the crisis, though the interpretations differ among analysts and are not necessarily incompatible. Some see it as simply as a policy mistake that, through the attempt by financial institutions to increase their returns in a low interest rate environment (the so called "search for yield"), led to risky investments. Others see it as a reflection of the need to compensate, particularly through expansionary monetary and credit policies, the weak aggregate demand generated by adverse trends in income distribution throughout the world. ${ }^{3}$

Global payments imbalances also figure prominently in the debate on the origins of the crisis, again with contrasting views, which are not necessarily compatible in this case. According to

\footnotetext{
${ }^{3}$ See, for example, an interpretation along the latter lines in UN (2009c). See also Akyüz (2010).
} 
one interpretation, Asian and, particularly, Chinese "mercantilism" generated massive surpluses that increased the demand for US financial assets and kept interest rates -including long-term rates - low. The alternative interpretation emphasizes rather the fact that the crisis that started in Asia and other emerging economies in 1997 made it clear that the world lacks an efficient mechanism to manage financial crises in developing countries, due to limited and highly conditional IMF lending and the lack of an international debt workout mechanism. According to this view, the rational response of developing countries to this institutional deficit was to "self-insure" themselves against crises by accumulating large amounts of foreign exchange reserves during the 2003-07 boom. This policy included large savings out of the windfall generated by high commodity prices as well as the decision to accumulate as additional foreign exchange reserves a large part (or even all) the additional pro-cyclical capital flows that came as a veritable flood during some phases of the boom. On top of that, its role as a "consumer of last resort" during the Asian crisis had dramatically increased US current account deficits. The persistence of high US deficits in later years made it increasingly clear that the international monetary system does not impose any discipline on the country issuing the dominant reserve currency, the problem widely known as the Triffin Dilemma. ${ }^{4}$

Viewed in particular from the perspective of the center of the financial turmoil and industrial countries' policy responses, the crisis has had six distinct phases. The first started with the collapse of the subprime market and, more generally, asset-backed securities in August 2007. The response of the authorities in industrial countries was to activate the role of central banks as "lenders of last resort" by making emergency financing to banks more readily available at lower interest rates. The US added an early though limited and temporary fiscal stimulus. The second phase started with the collapse and rescue of a major US investment bank, Bear Stearns, in March 2008. The lack of confidence among financial institutions in the quality of each others' balance sheets increased markedly after that event, generating reduced interbank lending and a much greater use of available central bank credit lines.

The collapse of another major US investment bank, Lehman Brothers, during the weekend of September 13-14, 2008, and the decision of the US government not to rescue it, marked the beginning of the third and, in regards to financial markets, the most dramatic phase of the crisis. During the week that followed, financial markets experienced total paralysis (a "credit freeze"), including of interbank lending and the market for commercial paper, thus seriously disturbing normal payments flows. Many other major financial institutions went bankrupt in both the US, Europe and some other countries and were now generally rescued, in a major correction of what was very soon perceived as a major policy mistake (to let a systemically important institution, such as Lehman, go bankrupt). Authorities in industrial countries responded with even more massive central bank financial activism which, with variants across the industrial world, included many new facilities, some of which facilitated access to central banks by some financial institutions that had traditional lacked such access, additional purchase of government debt and central bank interventions in several markets (commercial paper and mortage-backed securities), strengthening deposit insurance, designing different schemes to capitalize financial institution with public sector funds and, to a lesser extent, buying toxic assets.

The critical phase was over by late October, 2008, as reflected in renewed interbank lending and the reduction of interest rates in many segments of the market. This may be denoted as

\footnotetext{
${ }^{4}$ See, on these issues, Ocampo (2010) and the parallel essay by Griffith-Jones and Ocampo (2010).
} 
the beginning of a fourth phase, in which the worst of the financial panic was overcome but financial institutions continued to be seriously undercapitalized or were outright bankrupt but continued to operate under the implicit promise that in the end they would be bailed out. Since the second quarter of 2009 we can talk of a fifth phase, which came to be known as "green shoots", characterized by a significant reduction in risk premia and a recovery of stock prices and of bond markets, but no significant revival or even continued contraction of bank lending in industrial countries. In terms of new policy actions, the most remarkable development during the fourth and fifth phases was the shift by major central banks towards "quantitative easing" -that is, the outright increase in the money supply once central bank interest rates were brought down to zero (or near zero) and therefore ceased to be a useful instrument for further monetary expansion.

A reflection of the "green shoots" was a vigorous renewal of capital flows to developing countries, particularly to some of the emerging economies, reflecting both the return of risk taking and massive carry trade facilitated by low interest rates in industrial countries, that has generated a sixth phase. ${ }^{5}$ In the case of the latter, it is hard to talk of a new financial bubble, as credit remained subdued and some asset prices (particularly real estate) remained depressed. In contrast, in several of the so-called emerging countries signs of a new bubble in the making were already noticeable by the last quarter of 2009, as reflected in variable mixes of strong exchange rates, booming stock markets and, at least in a few (China being the most important), booming domestic credit and real estate prices. Worldwide, however, financial conditions remained quite unsettled, as reflected in periodic panics, associated with conditions in some countries (Dubai in late 2009 and Greece in early 2010, for example) or some markets (commercial property in the US). The major characteristic of this sixth phase is, therefore, the mix of unsettled world financial conditions with the great imbalances between financial developments in some emerging and. industrial economies. It may perhaps be characterized as the return of global imbalances.

An economic slowdown was already visible but was not dramatic during the first two phases of the crisis. In Europe (with the major exception of Great Britain), there was, however, a tendency to underestimate it in political circles, a fact that was reflected in the much more conservative attitude of the European Central Bank and the weaker fiscal stimulus adopted by Continental European countries. Responses in the US and Japan were more aggressive on both fronts. The dramatic recession in the industrial world that followed the financial meltdown of mid-September 2008 surpassed the most pessimistic expectations. GDP of industrial countries fell in the last quarter of 2008 and the first quarter of 2009 at an annual rate of 7 to $8 \%$, similar to that during the early phases of the Great Depression, and industrial production dived (see Figure 1.A). ${ }^{6}$ This was followed by a break in the contraction of economic activity during the fifth, "green shoots" phase. In the industrial world, recovery was led in the second quarter of 2009 by France, Germany and Japan but it spread to the US and most other countries in the third quarter.

\footnotetext{
${ }^{5}$ We can add that this is so much so that Roubini (2009) has referred to this phenomenon as the "the mother of all carry trade”.

${ }^{6}$ Quarterly GDP growth estimates here and in the following paragraph follow estimates by JPMorgan (2009-10).
} 
Figure 1: Industrial production, 2006-2009 (1st semester of 2008=100)

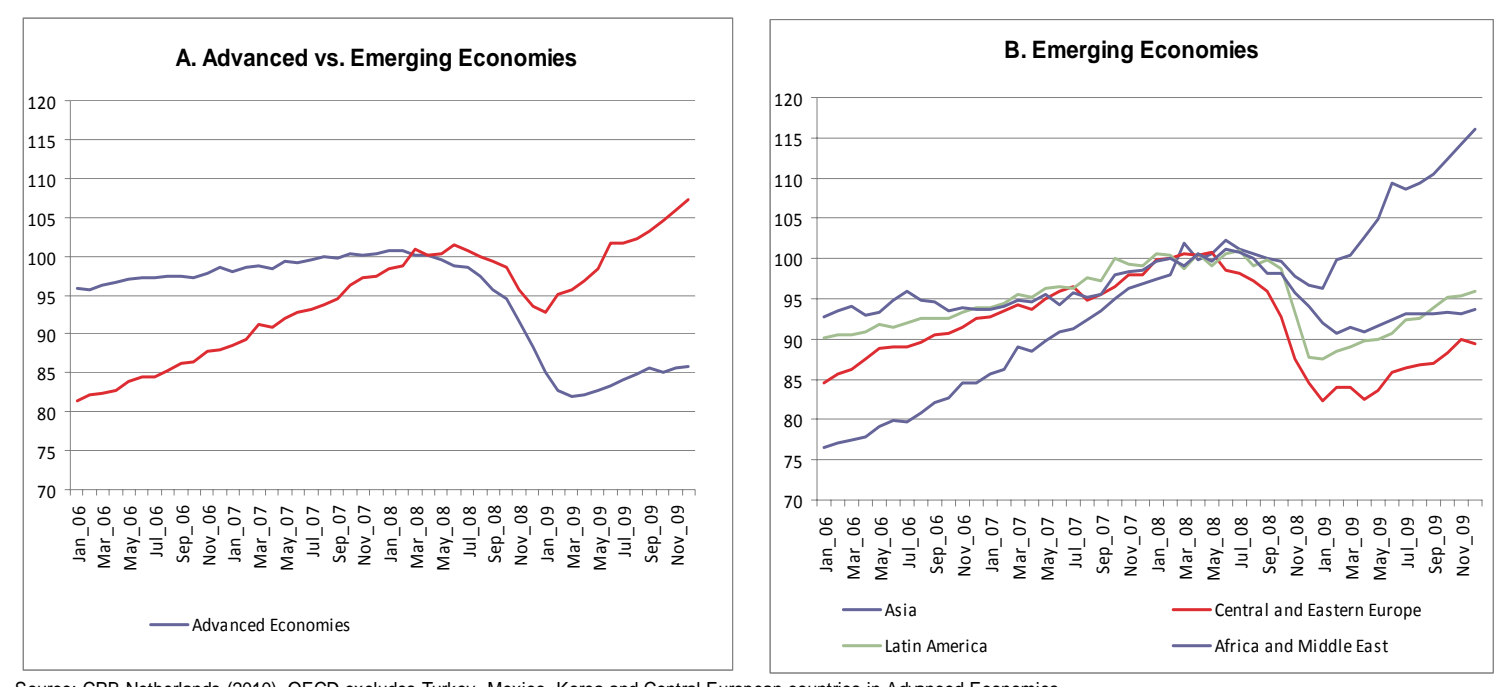

Source: CPB Netherlands (2010). OECD excludes Turkey, Mexico, Korea and Central European countries in Advanced Economies

Although developing countries were somewhat hit during the first two phases of the crisis, partly through reduced availability and higher costs of borrowing, most of them continued to grow relatively fast during the first semester of 2008 thanks, as we will see, to booming commodity markets and the perception that risks of lending to them were low. The fall of commodity prices since mid-2008 may be seen, therefore, as a more relevant turning point for many developing countries. In any case, the September 2008 financial meltdown was a far more important shock, and led to a contraction of industrial production and exports (see Figure 1 as well as Figure 5 below). The resulting reduction of emerging countries' GDP reached an annual rate of over $6 \%$ in the last quarter of the year and around $4 \%$ in the first quarter of 2009. This average reflects, though, the limited slowdown experienced by the two Asian giants, China and India, during the worst of the crisis, whilst in other emerging country regions and several East Asian economies was sharper and, in some cases matched the average pace of contraction of the industrial countries (see Figure 1.B in relation to industrial production).

The early return to the rapid expansion of emerging economies in the second quarter was largely Asia based, as other regions lagged with some major exceptions (Brazil in Latin America is a notable one), but the recovery became widespread in the third quarter of 2009 . By late 2009, the picture was, therefore, one of very uneven performance in the developing world. Looking at industrial production in emerging markets, Asia had surged above precrisis levels while all other regions remained below those levels, particularly Central and Eastern Europe.

Avoidance of a Great Depression like that of the 1930s was a considerable policy success, though there are still significant risks ahead, stemming from a possible early withdrawals of stimuli that could generate a double-dip recession and, particularly, from a long period of relatively slow growth in industrial countries and perhaps the whole world economy. Success can be attributed to two major factors. The first is massive policy interventions in the industrial world but also, as we will see, in several developing countries, notably China. This was reflected in the most massive Keynesian macroeconomic package in history. To this we should add the rescue of financial institutions, albeit with the major error of not doing so with 
Lehman. ${ }^{7}$ The second and crucial factor was the existence of a parallel engine of recovery, China. (India also performed well, but its links with other countries are much more limited than those of China). Indeed, one of the significant differences between the two eras was that there was no "China" in the 1930s: a substantial economy without a financial sector in crisis and with the foreign exchange and fiscal room to pursue aggressive Keynesian policies.

\footnotetext{
${ }^{7}$ The terms of the rescues contained many flaws, but this is beyond the scope of this paper.
} 



\section{2.- Channels of transmission of the crisis}

The crisis was transmitted to the developing world through the sharp reversal of the positive shocks it had experienced during the 2003-2007 boom. In quantitative terms, the two most important channels were the collapse of international trade (including commodity prices) and the paralysis of private capital markets. As we will see, while the financial channel tended to loosen during the fifth (green shoots) and sixth (return of global imbalances) phases, trade remained significantly below pre-crisis levels through the end of 2009, and indeed will continue to do so in 2010 according to existing projections. Whereas the financial shock was more severe for middle-income countries, the trade shock affected all economies, and its strength depended more on the commodity composition of exports and trade openness rather than on the level of development. A third transmission channel, the fall of migrant workers' remittances, was also significant for a subset of developing countries, mostly small economies. We look at these three channels in detail below, analyzing also the diverse effects they had throughout the developing world. The variations in the mix of shocks as well as of the policy responses by developing countries (and the policy space they enjoyed) explains the diversity of outcomes, which will be analyzed in part III.

\section{1.- REMITTANCES}

Although hard quantitative evidence is lacking, new migration flows seems to have fallen sharply as a result of the global financial crisis, but immigrants that were already settled were generally unwilling to return to their countries of origin, fearing that they would not be able to re-enter once they left because of tighter immigration controls. Nonetheless, initial World Bank expectations that remittances would be relatively resilient due to the latter factor (see, for example, Ratha et al, 2008) did not materialize. Overall, remittances fell from US\$338 billion in 2008 to US\$317 billion, a drop of $6.1 \%$, which overall represented a relatively small shock for the developing countries as a whole (0.1\% of GDP).

However, regional and national patterns diverged significantly from this average pattern (Ratha et al, 2009). Three regions, and some countries within them, stand out in terms of the significance of the shock experienced through the reversal of remittance flows: Latin America and the Caribbean, Eastern Europe and Central Asia, and some countries in North Africa. The common characteristic of these regions was their dependence on remittances from migrants living in the US, Western Europe and Russia. In contrast, those dependent on remittances from migrants to the Gulf Cooperation Council countries performed relatively well. Also, small countries within the regions most affected were the most badly hit, given their heavier dependence on remittance flows. 
Table 1: Remittances by Region (percentage change)

\begin{tabular}{|c|c|c|c|c|c|c|c|}
\hline Region & 2004 & 2005 & 2006 & 2007 & 2008 & 2009 e & $\begin{array}{c}\text { Impact Crisis } \\
\% \text { GDP }\end{array}$ \\
\hline Middle-East and North Africa & $13.1 \%$ & $8.4 \%$ & $4.6 \%$ & $20.1 \%$ & $10.6 \%$ & $-7.2 \%$ & $-0.3 \%$ \\
\hline Europe and Central Asia & $45.3 \%$ & $43.6 \%$ & $24.1 \%$ & $36.0 \%$ & $13.8 \%$ & $-14.7 \%$ & $-0.3 \%$ \\
\hline Latin America and Caribbean & $18.4 \%$ & $15.7 \%$ & $18.1 \%$ & $6.8 \%$ & $2.3 \%$ & $-9.6 \%$ & $-0.2 \%$ \\
\hline South Asia & $-5.5 \%$ & $18.2 \%$ & $25.3 \%$ & $27.1 \%$ & $35.6 \%$ & $-1.8 \%$ & $-0.1 \%$ \\
\hline Sub-Saharan Africa & $34.4 \%$ & $16.9 \%$ & $34.7 \%$ & $47.6 \%$ & $13.4 \%$ & $-2.9 \%$ & $-0.1 \%$ \\
\hline East Asia and Pacific & $23.4 \%$ & $25.1 \%$ & $14.1 \%$ & $23.8 \%$ & $20.8 \%$ & $-1.5 \%$ & $0.0 \%$ \\
\hline All Developing Countries & $17.1 \%$ & $21.0 \%$ & $18.3 \%$ & $22.9 \%$ & $16.7 \%$ & $-6.1 \%$ & $-0.1 \%$ \\
\hline
\end{tabular}

Latin America and the Caribbean was the region earliest hit. Remittances grew very slowly both in 2007 and 2008, falling as a proportion of GDP in both years, in sharp contrast with the rapid growth earlier in the decade (see Table 1). This was a reflection of the importance of employment of migrant workers in the US construction sector, which started experiencing a severe contraction since 2007 (JPMorgan, 2008). The strength of the crisis in Spain, the major destination of Latin Americans in Europe, added to that experienced by migrants to the US. Remittances started to fall in the third quarter of 2008. The contraction estimated by the World Bank and reported in Table 1 seem to low, as according to more recent and comprehensive information by the Inter-American Development Bank (2010) indicates that they fell by $15 \%$ in 2009 , with the strongest contraction experienced in the second and third quarters of that year, when they fell by $17 \%$. There are indications that remittances may have bottomed out in the last quarter of 2009, a fact that is consistent with the interruption of job losses for Latin American migrants in the US.

Although with some lag in comparison to Latin America and the Caribbean, Eastern Europe and Central Asia also experienced a strong negative shock from remittances in 2009, with an overall reduction of close to $15 \%$, equivalent to $0.3 \%$ of GDP. As we will see below, some former Soviet republics in Eastern European and Central Asian countries heavily dependent on remittances from migrants living in Russia were hit the hardest in relative terms. Among the new EU members, Poland and Romania, whose immigrants commonly chose U.K. as their destination, also suffered an important fall in remittance income during 2009 (21\% and 15\%, respectively).

Although remittances fell by less to North Africa and the Middle East, the largest average share of remittances in the income of these economies meant that this region was also significantly affected. Morocco and Egypt, the principal recipients in the region, which depend on migration to Europe, mainly France and Spain, experienced the sharpest contraction (20\% in the first half of 2009). Migrants to the Gulf countries (e.g., from Lebanon, another major recipient of remittances) fared much better.

Table 2 lists the 14 countries hardest hit in the developing world, where the remittance shock exceeded 1\% of GDP. The strongest affected were four former Soviet republics, and two additional ones also belong to the longer list. Six small Latin American and Caribbean countries were also strongly affected. In other regions, only Morocco in North Africa and Tonga in the South Pacific experienced a strong shock. Of the countries in Table 2, only two exceed a population of 10 million: Morocco and Guatemala. 
Table 2: Countries Hit Hardest by Fall in Remittances

\begin{tabular}{|lccc|}
\hline Country & $\begin{array}{c}\text { Change of } \\
\text { Remittance Flow } \\
\mathbf{2 0 0 9}\end{array}$ & $\begin{array}{c}\text { Remittances as a } \\
\text { share of GDP, 2008 }\end{array}$ & $\begin{array}{c}\text { Impact } \\
\text { \% GDP }\end{array}$ \\
\hline Tajikistan & $-28.7 \%$ & $49.6 \%$ & $-14.2 \%$ \\
Moldova & $-21.4 \%$ & $31.4 \%$ & $-6.7 \%$ \\
Kyrgyz Republic & $-17.9 \%$ & $27.9 \%$ & $-5.0 \%$ \\
Armenia & $-30.0 \%$ & $8.9 \%$ & $-2.7 \%$ \\
Honduras & $-10.6 \%$ & $20.1 \%$ & $-2.1 \%$ \\
Jamaica & $-11.9 \%$ & $14.5 \%$ & $-1.7 \%$ \\
El Salvador & $-9.0 \%$ & $17.2 \%$ & $-1.6 \%$ \\
Georgia & $-27.0 \%$ & $5.7 \%$ & $-1.5 \%$ \\
Tonga & $-3.7 \%$ & $37.7 \%$ & $-1.4 \%$ \\
Morocco & $-17.0 \%$ & $8.0 \%$ & $-1.4 \%$ \\
Haiti & $-6.1 \%$ & $18.7 \%$ & $-1.1 \%$ \\
Guyana & $-4.6 \%$ & $24.0 \%$ & $-1.1 \%$ \\
Azerbaijan & $-30.1 \%$ & $3.4 \%$ & $-1.0 \%$ \\
Guatemala & $-8.7 \%$ & $11.4 \%$ & $-1.0 \%$ \\
\hline Source: See Table 1. & & & \\
\hline
\end{tabular}

In contrast to the previous pattern, remittance flows to South Asia, a region with heavy dependence on this source of income, grew strongly up to 2008 and experience only a small fall in 2009 despite the global economic crisis. Dependence on migration to the Gulf countries was the stabilizing factor in this case. In some of the major countries of the region, remittances actually increased in 2009, especially as construction activities in the Gulf remained robust (though after the crisis of Dubai World in late 2009, there are concerns that this may change). This is the case of Pakistan, Bangladesh and Nepal. This is also true of the major recipient of migrant income in East Asia after China, the Philippines Similarly, transfers to sub-Saharan Africa, which come in large measure from other countries in Africa and the Middle East, proved resilient.

Changes in exchange rate played a critical role in the divergent performances during the crisis. One of the major explanations of the sharp fall in remittances from Russia was indeed the depreciation of the ruble. Ecuador, a dollarized economy with heavy migration to Spain experienced first an adverse and then a positive effect of the variations of the euro/dollar exchange rate. Polish and Romanian migrants to the U.K. were negatively affected by the depreciation of the British pound. Since several recipient countries experienced a depreciation of their own currencies, this factor operated in a favorable way, compensating and even overcompensating for the reduction of remittances in dollar terms. For example, in Mexico and Colombia, the two largest recipients of remittances in Latin America in absolute terms, domestic recipients actually saw an increase in the domestic purchasing power of remittance flows thanks to the depreciation of their pesos. It has also been argued that the depreciation of the domestic currencies may have increased remittances to Philippines and South Asia, as it created an incentive for migrants to buy long term assets such as housing, bank deposits and stocks in their countries of origin. (Ratha et al., 2009)

\section{2.- FINANCIAL FLOWS}

The financial channel had been at the center of the two major crises in the developing world in previous decades: the debt crisis of the 1980s and the Asian crisis of the late 1990s. Following a long history of boom-bust cycles (see, for example, Reinhart and Rogoff, 2009), 
the essential feature in both cases was the sharp change from booming financial conditions to a sudden interruption in lending from international capital markets (to either sovereign or corporations), together with outflows of the most volatile capital (short-term lending and some portfolio flows) and the rapid increase in spreads -the phenomenon that has come to be broadly referred to as a "sudden stop", but is often in fact a reversal of flows.

Imitating this pattern, the recent global financial crisis also hit hard private capital flows to the developing world, as reflected in a strong interruption of new lending, massive outflows of volatile capital and a rapid increase in spreads. Although some financial indicators (stock exchange prices and bond spreads) had been hit by both the sub-prime crisis in August 2007 and the fall in commodities in mid-2008, the strongest shock only came with the world financial meltdown of September 2008. However, it turned out to be much less intense than in previous crises. There are two major explanations for this result: the strengthening of developing countries' external balance sheets during the boom, and the strong countercyclical policy reaction in industrial countries, particularly by their central banks. We return to the first of these issues in part III, whereas the second was already mentioned above. It must be said that this strong counter-cyclical action was largely absent during the major developing country crises of the last two decades of the twentieth century, where it was limited to additional and highly conditional IMF lending and, with significant lags, initiatives to reduce the debt burden (the 1989 Brady Plan, the failed discussion of a Sovereign Debt Restructuring Mechanism in 2001-2003, and the initiatives to reduce the debt of highly indebted poor countries). ${ }^{8}$ Indeed, the only major exception was the strong reaction of the US to bail out Mexico after the crisis that erupted in that country in December 1994, which made that crisis one with mild global effects (although certainly not on Mexico and some other economies, particularly Argentina).

As regards to volumes of flows, private financial flows peaked from mid-2006 to mid-2007. After a short weakening during the third quarter of 2007 due to the sub-prime crisis, they recovered and boomed again during the first semester of 2008, though concentrated in mutual funds flows, but dropped very sharply in the third quarter of 2008 and were low or became sharply negative during the last quarter of 2008 and throughout the first quarter of 2009. This was the result of a steep and simultaneous fall-off in all cross-border capital flows, including equity flows, issuance of debt securities and cross-border lending, as well as a sharp change from large inflows into a large outflows from mutual funds (Figure 2.A). Emerging countries' equity markets and liquidity in bond markets sharply worsened, as the whole global financial system seemed to crumble after the Lehman collapse. There was virtually no sovereign or corporate bond or equity issuance from emerging economies in international markets between mid-September and mid-December 2008. Local stock markets, meanwhile, experienced the worst yearly decline in recent history, as the MSCI Emerging Market Index dropped 55\% during 2008, erasing some US\$17 trillion in market valuation (World Bank, 2009b, Overview). Thus, as in previous crises, contagion moved across categories of flows and was experienced by all developing country regions (Figure 2.B).

\footnotetext{
${ }^{8}$ See again on this the parallel paper by Griffith-Jones and Ocampo (2010).
} 

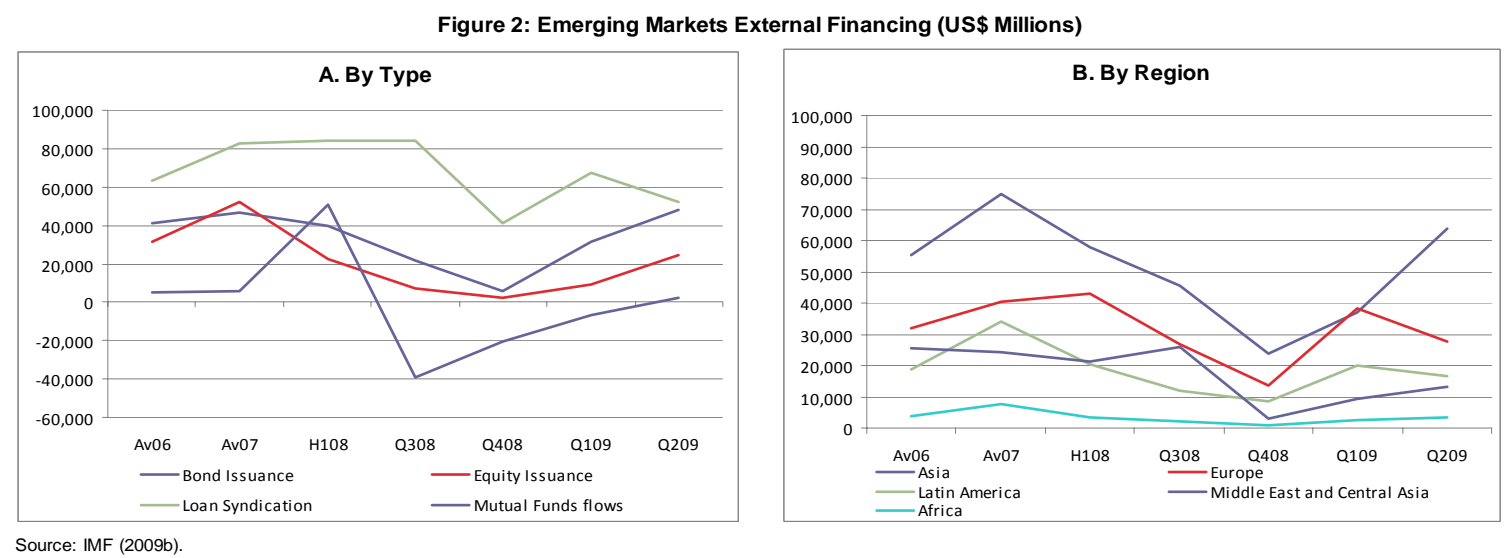

In annual figures for 2008, the outflows after the Lehman collapse prevailed over the positive flows during the first semester, generating net private financial outflows (i.e., private flows excluding FDI) for US\$296 billion vs. net inflows for US\$285 in 2007; net financial outflows continued to be massive in 2009, US\$331 billion (see Table 3). The sharpest drop was in international bank lending, with a substantial net inflow that turned into a large outflow in 2008 and 2009 (this is reflected in the category other private flows, in Table 3). Data from the Institute of International Finance (IIF) and other sources confirm this rapid fall in bank lending into negative net lending. Only foreign direct investment, which tends to be more resilient to a crisis given the longer-term horizon of investors -though perhaps less than much of the literature expected-, and the longer gestation periods of the projects being financed, remained positive, but still decreased from US\$425 billion in 2008 to US\$279 billion in 2009. By region, almost all the increase of capital flows during the boom occurred in large middleincome countries, while the sharpest decline was that experienced by the emerging economies of Europe (World Bank, 2009b, chapter 2). 
Table 3: Developing and Transition Economies Capital Flows, US\$ billion

\begin{tabular}{|c|c|c|c|c|}
\hline Region & 2006 & 2007 & 2008 & 2009 \\
\hline \multicolumn{5}{|c|}{ Emerging and developing economies } \\
\hline Private financial flows, net & 261.98 & 696.53 & 129.52 & -52.49 \\
\hline Direct investment, net & 254.39 & 411.25 & 425.02 & 278.97 \\
\hline Private portfolio flows, net & -32.36 & 88.14 & -85.36 & -99.84 \\
\hline Other private financial flows, net & 39.95 & 197.14 & -210.14 & -231.62 \\
\hline Official flows, net & -140.23 & -69.46 & -105.66 & 50.35 \\
\hline Total net flows & 121.74 & 627.07 & 23.86 & -2.14 \\
\hline \multicolumn{5}{|l|}{ Africa } \\
\hline Private financial flows, net & 6.86 & 30.03 & 28.55 & 21.04 \\
\hline Direct investment, net & 20.27 & 31.49 & 41.86 & 26.45 \\
\hline Private portfolio flows, net & 17.12 & 9.82 & -20.83 & 5.20 \\
\hline Other private financial flows, net & -30.53 & -11.28 & 7.52 & -10.62 \\
\hline Official flows, net & 6.56 & 6.62 & 5.98 & 15.57 \\
\hline Total net flows & 13.42 & 36.65 & 34.53 & 36.61 \\
\hline \multicolumn{5}{|l|}{ Central and eastern Europe } \\
\hline Private financial flows, net & 118.76 & 185.53 & 154.71 & 6.40 \\
\hline Direct investment, net & 64.44 & 77.10 & 69.33 & 31.84 \\
\hline Private portfolio flows, net & -0.41 & -2.91 & -9.92 & -7.46 \\
\hline Other private financial flows, net & 54.72 & 111.34 & 95.30 & -17.99 \\
\hline Official flows, net & 3.83 & -6.38 & 21.06 & 34.52 \\
\hline Total net flows & 122.58 & 179.15 & 175.77 & 40.91 \\
\hline \multicolumn{5}{|c|}{ Commonwealth of Independent States } \\
\hline Private financial flows, net & 56.21 & 124.89 & -97.44 & -98.52 \\
\hline Direct investment, net & 21.36 & 28.25 & 49.08 & 16.64 \\
\hline Private portfolio flows, net & 12.74 & 15.77 & -31.32 & 2.63 \\
\hline Other private financial flows, net & 22.12 & 80.87 & -115.20 & -117.79 \\
\hline Official flows, net & -30.25 & -1.62 & -25.74 & 20.81 \\
\hline Total net flows & 25.97 & 123.27 & -123.17 & -77.71 \\
\hline \multicolumn{5}{|l|}{ Developing Asia } \\
\hline Private financial flows, net & 54.86 & 200.61 & 35.68 & -54.26 \\
\hline Direct investment, net & 84.74 & 153.05 & 139.81 & 93.41 \\
\hline Private portfolio flows, net & -50.87 & 63.20 & 7.95 & -85.18 \\
\hline Other private financial flows, net & 20.99 & -15.64 & -112.08 & -62.49 \\
\hline Official flows, net & -2.38 & 6.21 & -0.32 & 3.57 \\
\hline Total net flows & 52.48 & 206.82 & 35.36 & -50.70 \\
\hline \multicolumn{5}{|l|}{ Middle East } \\
\hline Private financial flows, net & -11.59 & 43.30 & -58.93 & 48.02 \\
\hline Direct investment, net & 34.13 & 34.75 & 34.49 & 39.52 \\
\hline Private portfolio flows, net & -22.48 & -36.10 & -10.66 & 1.49 \\
\hline Other private financial flows, net & -23.24 & 44.66 & -82.77 & 7.00 \\
\hline Official flows, net & -74.36 & -73.43 & -110.21 & -51.59 \\
\hline Total net flows & -85.94 & -30.12 & -169.14 & -3.58 \\
\hline \multicolumn{5}{|l|}{ Western Hemisphere } \\
\hline Private financial flows, net & 36.88 & 112.17 & 66.95 & 24.84 \\
\hline Direct investment, net & 29.46 & 86.62 & 90.44 & 71.10 \\
\hline Private portfolio flows, net & 11.52 & 38.36 & -20.58 & -16.52 \\
\hline Other private financial flows, net & -4.10 & -12.80 & -2.91 & -29.74 \\
\hline Official flows, net & -43.64 & -0.87 & 3.57 & 27.47 \\
\hline Total net flows & -6.75 & 111.30 & 70.52 & 52.32 \\
\hline
\end{tabular}

Two caveats should be made, however, about these trends. First of all, the falls in net private flows, though deep, were smaller to those that were forecast at the depth of the crisis. This can be seen by comparing Institute of International Finance January 2009 forecast (IIF, 2009), which was somewhat more optimistic than that made by this institution in October 2008, vs. more recent estimates (IIF, 2010), but this reflects a general pattern. They were excessively pessimistic about Latin America and emerging Asia, but too optimistic about emerging Europe, which turned out even worse. The second caveat is that, in sharp contrast with 
previous crises, the collapse in private flows to emerging economies was much shorter in duration. We return to this issue below.

The impact of the global financial crisis has been more severe for emerging markets than for low-income countries, which are less integrated into international private capital markets. Indeed, capital flows to low-income Africa have been the most stable as well as relatively limited (see Table 3). However, detailed surveys conducted by Bhinda and Martin (2009) indicate that private flows to low income countries are both higher and more volatile than either IMF or national authorities statistics show. One important reason why such survey data reports higher flows to Sub Saharan Africa is that they measure better South-South private flows, which are also reportedly more stable. As regards to volatility, Bhinda and Martin (2009) underscore that all categories of flows to low income countries are volatile, and debt flows particularly so. Furthermore, they stress that capital flows, and especially FDI, can be huge in relation to the size of their economies, which are often less diversified than middle income countries, as their growth may depend on one or two large projects. This makes low income countries particularly vulnerable to negative effects on employment, income and poverty of volatility of capital flows, especially FDI.

The economies in transition, including the former Soviet-bloc countries of Central and Eastern Europe that are now members of the European Union, experienced the most dramatic reversal, having been heavily dependent on bank financing and rising levels of external debt, therefore feeling strongly the consequence of worldwide deleveraging. Developing Asia also suffered a major reversal, especially if compared with their 2007 peak. Countries with large current-account deficits (compounded in many cases by currency mismatches in private sector's balance sheets) and therefore most dependent on foreign capital, were hardest hit by the substantial tightening of credit conditions; this is indeed the reason why Central and Eastern Europe was so strongly affected, recalling the patterns of the Latin American economies during the crises of the last two decades of the twentieth century. However, even middle-income countries with current-account surpluses were substantially affected by the global financial crisis. Many of them experienced a sell-off in assets that triggered an important depreciation of exchange rates. Thus, the reversal of portfolio flows in East and South Asia was large and even surprising in several cases. Economies like India and Taiwan also saw negative portfolio investment flows. In Latin America, Brazil and Mexico were hit by losses in derivative markets and, in the first case, by the unwinding of the carry trade. South Africa was also severely hit.

Furthermore, net financial resources continued to flow from poor to rich countries. According to United Nations estimates (UN, 2010a), developing countries as a group continued to provide net financial transfers (defined as net capital flows less investment income payments) to developed countries in 2009 at a level of US\$568 billion (Figure 3). While still substantial, this amount is notably lower than the US\$891 billion reached in 2008. 


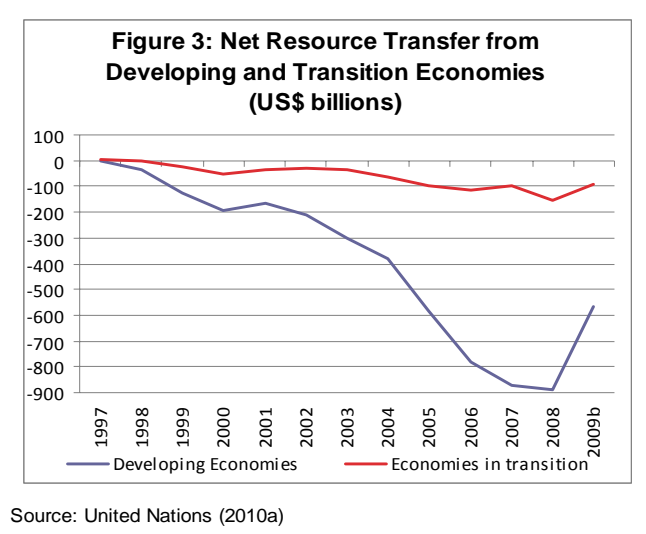

As indicated, from the point of view of emerging countries' access to financial markets, the worst of the financial collapse was rather short by previous historical records. By far the worst moment was the last quarter of 2008. As Figure 2.A indicates, bond issuance started to recover in the first quarter of 2009, and remained high since (see more recent data in IIF, 2010). It was followed, though in a more inconsistent manner, by loan syndication, and in a weaker way, by equity issuance and mutual funds flows. For the second quarter of 2009, for which the last consolidated data is available, overall flows were still about two-thirds of the peak levels of 2007 and the first semester of 2008. As we can see in Figure 2.B, flows to Asia and, to a lesser extent, the Middle East experienced a more sustained rebound in the first half of 2009, whilst Europe and Latin America faltered in the second quarter of 2009. This was accompanied by a rebound in stock markets in both developed and most emerging markets.

The basic explanations for this rapid revival were the sharply expansionary macroeconomic policies in industrial countries, as well as policy measures to recapitalize financial institutions. Particularly important were the massive monetary expansion and lowering of interest rates in developed countries, which led to high international liquidity and the search for better yields than could be obtained in developed countries (the well known push factors). This combined with increase in risk appetite, to use the traditional expression discussed below, but also increasingly reflecting the view that many developing countries have better growth prospects than developed ones, and possible less fragilities Equity prices in emerging markets experienced a strong recovery, as part of the worldwide rebound.

One of the reflections of the initial collapse and early revival of capital flows is the evolution of the JPMorgan's Emerging-Market Bond Index (EMBI). As Figure 4 indicates, emerging market spreads had started to increase moderately since the start of the financial crisis in August 2007, but that increase was largely compensated by the decline in the long-term US interest rates that serve as a benchmark, thus keeping 10-year bond yields rather constant around 6.5\%, with only moderate upward trends during the third quarter of 2007 (the subprime crisis) and the third quarter of 2008 (the end of the commodity price boom). Spreads increased sharply after the Lehman collapse, bringing yields also sharply up despite the reduction in benchmark interest rates. However, after peaking in late October 2008 (a yield of 13.5\%), they started to moderate and sharply so since March 2009. By October 2009, yields were essentially back to the pre-Lehman levels, reflecting a higher spread (of about 100 basis points) compensated by a reduction in the benchmark interest rate. Viewed in terms of the long sequence of high spreads and yields that characterized the post-Asian and, particularly post-Russian crisis developing world, in which it took five years to return to pre-crisis levels, the recent one-year cycle was surprisingly short (see again Figure 4). Indeed, spreads did not 
even reach the levels of the previous major disturbance: that generated in 2002 by the presidential elections in Brazil.

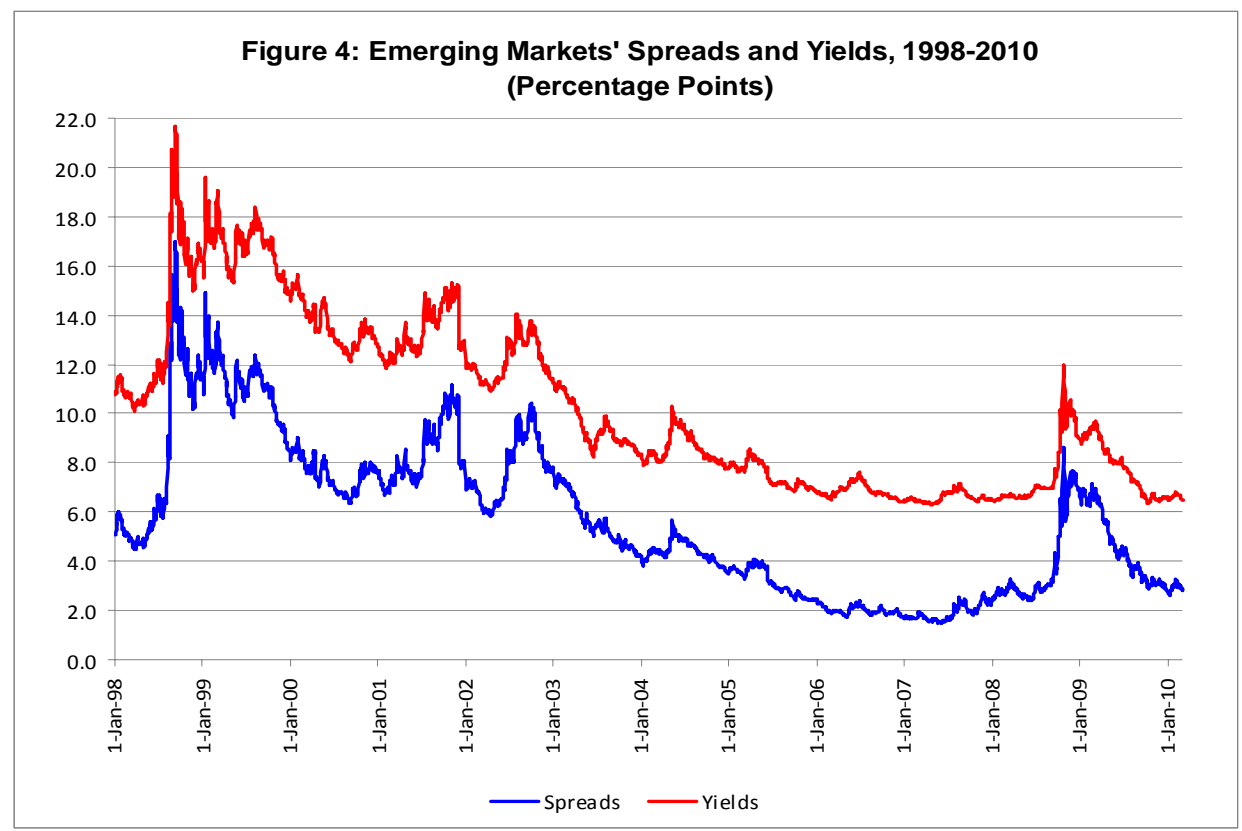

Source: JP Morgan

Financial investors have thus rediscovered an appetite for risk in high-yielding currencies and emerging market equities. The IIF starts its January 2010 report by characterizing recent trends in capital flows to emerging economies as "Famine to Feast", as the outlook in terms of growth and tighter fiscal stance looks actually better in many emerging economies than in developed ones. The IMF refers to this development in its latest Global Financial Stability Report (IMF, 2010b) warning that the decline in sovereign debt spreads has been driven almost entirely by an improved global appetite for risk and core market liquidity, despite underlying economic fundamentals continuing to deteriorate in some countries.

This creates a fear that speculative motives associated with returning portfolio flows could become a source of another global financial bubble in the making, this time in major emerging economies, as asset markets rise and exchange rates get overvalued. Bursting of this bubble could again be very costly for the developing world. At least, it could lead to increased volatility in exchange rates and assets prices and, hence, renewed macroeconomic instability, should appetite for risk in developing countries by foreign investors and lenders fall, or the perception of emerging and developing country risk deteriorate. One of the major reasons is the renewed importance of carry trade, which may remain an essential feature of the world economy, given the need of industrial countries to keep interest rates low for a long period of time, a pressure that is certainly absent in developing countries. This means that the carry trade has become a central source of external vulnerability for developing countries, which may require attention from both national and international regulators.

\section{3.-. TRADE}

In recent decades, world trade has shown two important features. First, it has tended to expand more rapidly than world production, a process that has been accompanied by a rapid diversification of trade structure. Thus, according to UN data, during the recent trade boom, in 
2003-2006, world trade volumes grew at an annual rate of 9.3\%, more than twice the rate of growth of world output (3.8\%) (UN, 2009a, Table I.1). Second, these rates of growth have been highly elastic to world output through the business cycle and have, therefore, been more volatile than world production. A major implication of this characteristic is that, although trade enhances world business cycle upswings, it equally tends to multiply downswings. The effects of the pro-cyclical pattern of capital flows to developing countries is therefore reinforced by the pro-cyclical performance of trade volumes and the more traditional one of commodity prices, thus generating a succession of strong positive and negative shocks that the more open contemporary developing countries face through the business cycle.

Following this pattern, the growth of trade volume experienced a strong slowdown since mid2007, and turned negative in September 2008. However, the collapse that followed (at an annual rate of $-32 \%$ between the third quarter of 2008 and the first quarter of 2009) had few historical precedents, as indeed it was more severe than that during the initial phase of the Great Depression (O’Rourke, 2009). The collapse in trade was triggered by the severe decline in global aggregate demand and associated inventory adjustments, compounded by a considerable strain in global financial markets, resulting in a shortage of trade credits. Economies most open to trade therefore received a dramatic shock, which explains the initial rapid reduction of GDP in the most trade-dependent economies, from Asia (Japan and the Asian Tigers: South Korea, Taiwan, Hong Kong and Singapore) to Germany, Mexico and Turkey.

Although the trough was reached during the first quarter of 2009 and there was an important recovery during the second semester, by the end of the year world trade volumes remained significantly below their peak reached during first semester of 2008, which serves as a reference point in Figure 5. As a consequence, yearly averages of world trade volumes grew only $2.4 \%$ in 2008 and decreased by $13.2 \%$ in 2009, compared to the annual rate of growth of 9.3\% in 2003-2006 (the same with this data base as with UN statistics).

Figure 5: Trade Export Volumes 2006-2009 (1st semester of 2008=100)

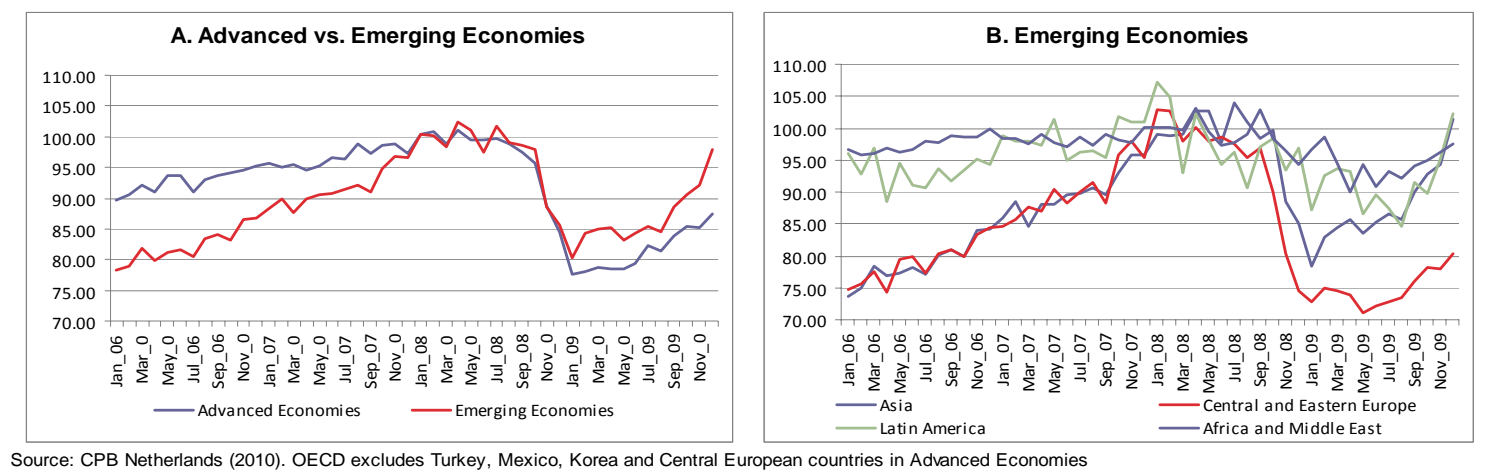

No region or indeed country was spared the adverse demand shock, reflected in the fall of volume of exports. In the developed world, the European Union and Japan experienced the hardest shocks, greater than 4\% of their GDP (UN, 2010a). Regarding developing countries and economies in transition, Central and Eastern Europe and Asia experienced the sharpest drop in volume, but the recovery of Asia came early in 2009 as, at the other end of the spectrum, Central and Eastern European exports stagnated at levels about 25\% below their peak (Figure 5.B). Countries in Africa and the Middle East were the least affected through the export volume channel. Latin America faced an intermediate situation. 
Manufacturing trade volumes faced the strongest contraction, reflecting a higher income elasticity than trade in commodities (UN, 2010a). Since developed countries are the main importers of manufactures, the contraction of demand in these countries was transmitted in unprecedented magnitudes through this channel. Furthermore, given their high dependence on manufacturing exports, Central and Eastern Europe and East and South-East Asian countries were the most affected, as well as Mexico and Turkey. China was not spared from this shock but was able to compensate it through massively expansionary domestic demand policies. As manufacturing export prices also experienced a reduction, several of these economies saw the value of manufacturing exports decline by $30 \%$ or more on a year during the first quarter of 2009. China again was also hit, as its export revenues were in the first quarter of 2009, $20 \%$ below the level of the same quarter one year earlier, and continued below 2009 levels despite the recovery that started in the third quarter of the year.

In the case of developing countries more dependent on commodity exports, the price channel was more important, and implied the sharp reversal of the positive terms of trade shock they had experienced during the boom years. Indeed, from 2004 to mid-2008, the world economy had experienced the most spectacular commodity boom in over a century, both in terms of its duration (five years), intensity and product coverage (World Bank, 2009a, chapter 2; UNCTAD, 2009, chapter III). However, as Table 4 indicates, the boom was stronger for energy and mining products (metals) than for agricultural goods. This is reflected in the fact that, whereas at their peak, during the first semester of 2008, real mineral prices nearly doubled the average levels of the 1970s (which were just below real averages for 1945-1980 for non-oil commodities), real agricultural prices just returned, and briefly so, to those earlier levels. In other words, agricultural prices just reversed during the recent boom, and temporarily so, the significant deterioration they had experienced during the 1980s and the Asian crisis. Oil did even better, as it quadrupled in real terms the already high historical average of the 1970s.

Table 4: Real commodity prices $(1971-80=100)$

\begin{tabular}{|c|c|c|c|c|c|c|}
\hline & $\begin{array}{c}\text { Total } \\
\text { non-oil }\end{array}$ & $\begin{array}{c}\text { Total } \\
\text { Agriculture }\end{array}$ & $\begin{array}{c}\text { Tropical } \\
\text { Agriculture }\end{array}$ & $\begin{array}{c}\text { Other } \\
\text { Agriculture }\end{array}$ & Metals & Oil \\
\hline \multicolumn{7}{|l|}{ Annual } \\
\hline 2003 & 66.2 & 63.9 & 50.7 & 77.3 & 76.9 & 123.8 \\
\hline 2004 & 73.5 & 67.9 & 58.8 & 77.2 & 99.1 & 151.3 \\
\hline 2005 & 79.5 & 71.9 & 64.8 & 79.2 & 114.7 & 213.8 \\
\hline 2006 & 97.2 & 79.1 & 68.7 & 89.7 & 181.0 & 253.5 \\
\hline 2007 & 106.1 & 87.8 & 76.4 & 99.3 & 190.7 & 265.9 \\
\hline 2008 & 110.3 & 97.4 & 91.0 & 103.8 & 169.8 & 342.4 \\
\hline 2009 & 94.6 & 85.8 & 79.9 & 91.9 & 135.0 & 234.2 \\
\hline \multicolumn{7}{|l|}{ Quarterly } \\
\hline I-2008 & 121.2 & 105.8 & 100.3 & 111.4 & 192.4 & 339.8 \\
\hline 2008-II & 119.8 & 104.0 & 102.8 & 105.3 & 192.8 & 413.5 \\
\hline 2008-III & 111.5 & 97.4 & 92.1 & 102.9 & 176.2 & 396.6 \\
\hline 2008-IV & 87.1 & 81.2 & 67.5 & 95.1 & 114.3 & 208.8 \\
\hline I-2009 & 84.4 & 80.8 & 69.4 & 92.4 & 101.1 & 170.0 \\
\hline 2009-II & 94.4 & 87.7 & 79.8 & 95.7 & 125.3 & 228.8 \\
\hline 2009-III & 97.0 & 86.0 & 82.2 & 89.8 & 148.0 & 257.8 \\
\hline 2009-IV & 102.2 & 88.8 & 87.7 & 89.9 & 164.1 & 278.0 \\
\hline
\end{tabular}

Source: Based on the methodology of Ocampo and Parra (2003)

Nominal prices deflated by World Bank's MUV up to 2008; quarterly evolution of manufacturing prices in 2008-2009 according to CPB Netherlands (2010)

The difference in performance between energy and minerals, on the one hand, and agricultural goods, on the other, indicates that the determinants of both commodity groups have been very 
different. In the case of energy and minerals, low prices led to low investment levels from the mid-1980s to the early 2000s. Low production capacity then met in recent years the high demand generated by rapid world economic growth and, in the case of metals, the unprecedented Chinese demand. Investment responded to high prices but there is a significant lag between investment decisions and increased supplies, leading to a long and strong price boom. In the case of agriculture, and despite the alarms raised by the food crisis during the first semester of 2008, supply-demand imbalances were more moderate and were more rapidly corrected. An important channel of transmission of high energy prices to agricultural markets was, of course, the increasing demand for biofuels (von Braun, 2007). The sharply increased financialization of commodity futures trading since 2005 also helped to speed up the price boom -and the succeeding collapse (UNCTAD, 2009, chapter III). Dollar depreciation during the second semester of 2007 and the first semester of 2008 also fueled the boom in dollar terms.

Commodity prices started to fall from mid-2008. The price turnaround clearly preceded the September financial meltdown, but was transformed into a veritable price collapse after this event. By December real agricultural prices were back to levels only slightly above those experienced during the Asian crisis. Prices for energy and metals fell more strongly but in real terms the level reached in the first quarter of 2009 was still historically high in the first case and much better than previous troughs in the second. In turn, the contraction in agriculture was stronger for tropical products than for temperate zone products. Recovery also started in the second quarter, and was again stronger for energy and minerals than for tropical agricultural goods (Table 4). All of them remained, however, below levels reached during the previous boom, and in the case of agriculture some $10 \%$ below the level of the 1970s. As noted above, the financialization of commodity markets reinforced the price collapse after September 2008 and the recovery since the second quarter of 2009.

Services trade was more resilient than merchandise trade, in part because an important share is destined for personal consumption rather than investment. However, tourism represented an exception, since it is a luxury and therefore income elastic. Developing countries, countries with important trade service sectors such as Brazil, Indonesia, Mexico and the South Korea were also hit by this channel, as their service export revenues fell. Mexico, with an important tourist sector, experienced a fall of more than 16\% in the first quarter of 2009 (UN, 2010a). Regionally, Central and Eastern Europe recorded the largest fall in tourism (11\%), while Africa registered a modest increase in tourist arrivals though a small decline in tourism receipts (World Bank, 2010).

A major implication of the aforementioned patterns is that trade shocks were very unevenly distributed throughout the developing world. This is well illustrated in UN estimates of trade shocks as a proportion of GDP, which captures both changes in the demand for exports, in volume terms, as well as terms of trade changes. Figure 6 reproduces the most recent estimates (UN, 2010b). As panel A in this figure indicates, energy exporters experienced the strongest positive shock during the previous boom, followed by mineral and manufacturing exporters (though the mineral price boom came to an end earlier). The magnitude of the negative shock in 2009 came exactly in the same order. In contrast, agricultural exporters received a weak positive shock and a neutral one during the crisis. This reflects the fact that many agricultural exporters in the developing world are also energy importers, so that what they won and lost through variations in the prices of the commodities they exported was largely compensated by losses and gains in their energy imports. Regionally, panel B 
indicates that West Asia and the economies in transition received the strongest positive and negative shocks, whereas Latin America received the weakest. Asia and Africa were, in this case, in the intermediate position.

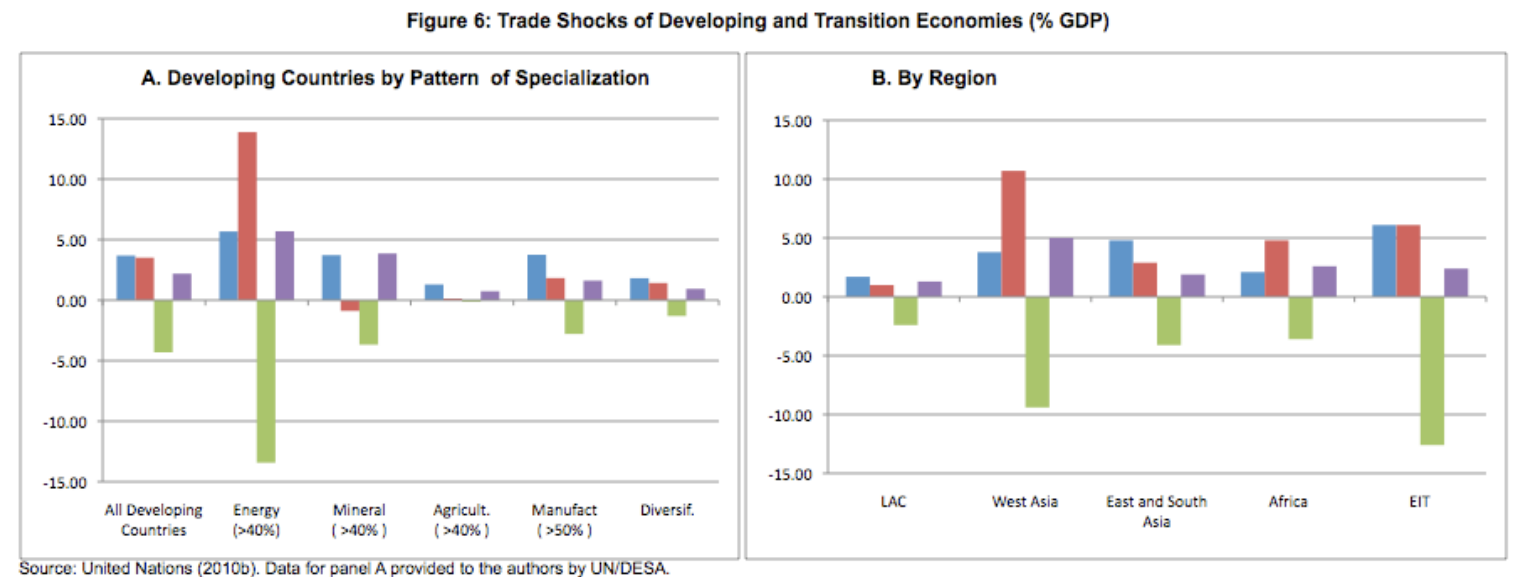

The contraction of international trade may at the end be the most important channel of transmission of the world financial crisis to the developing world. As we have seen, with some exceptions, the remittance channel was overall small and the financial channel intense but short. In contrast, through trade the developing world went from experiencing a positive shock equivalent to $3.5 \%$ of GDP up to 2008 to a negative one of $4.3 \%$--an astonishing change equivalent to 8 percentage points of GDP! Furthermore, this is a negative shock that developing countries had more limited capacity to counteract, given the restructuring that has been taking place for three decades towards more open economies, and the worldwide collapse of world trade, which gave them very limited scope to export themselves out of the crisis, the strategy that most of them followed during previous, developing country-centered crises. Not least important, though the recovery of trade will continue in 2010, recent projections by the UN (2010a) and IMF (2010a) indicate that trade volumes would only recover in the current year part of the 2009 losses and will remain 7 to $8 \%$ below 2008 levels. This poses serious questions on development strategies in the developing world, an issue to which we return in the concluding section of this paper.

\section{3.- POLICY RESPONSES AND OUTCOMES}

\section{1.- POLICY SPACE AND COUNTER-CYCLICAL POLICIES}

Given the worldwide trend towards external opening of both trade and financial accounts over the past decades, the recent crisis had severe effects throughout the developing world. As indicated at the end of the previous section, the space for developing countries to export themselves out of the crisis was simply not available this time. The space for and effectiveness of counter-cyclical domestic demand policies played, therefore, the crucial role in the capacity of individual developing countries to mitigate the strong external shock. 
In this area, there was a significant change in relation to past developing country-centered crises: there was broad-based support for developing countries' counter-cyclical macroeconomic policies. Indeed, this term, which had tended to disappear from the jargon of orthodox economists and economic authorities, as well as from the IMF, now made a victorious return. Support for counter-cyclical policies also came from the G-20 and the IMF, with some caveats in the latter case on whether developing countries could afford them and, particularly, whether governments that came to the IMF for financing should adopt them. But this shift was not always reflected in practice,

Due to the procyclical pattern of external financing that developing countries face, the room of maneuver for expansionary domestic demand policies during crises has invariably been limited by balance of payments constraints. For that reason, the crucial difference this time was the much stronger external balance sheets that developing countries had been building up. This was, first of all, the result of the "self-insurance" against balance of payments crises that they had practiced on a broad-based basis and in some regions on a massive scale during the boom and was reflected in the accumulation of large foreign exchange reserves (Ocampo, 2010). This was mixed with also fairly broad-based reductions in external public sector debts, thanks to the development of domestic bond markets in several developing countries after the Asian crisis, the debt relief initiatives that had been in pace, particularly for low-income countries (the Highly-Indebted Poor Countries or HIPC Initiative, its successor, the Multilateral Debt Relief Initiative), and some individual debt restructuring processes either in the context of the Paris Club (e.g., Iraq and Nigeria) or through unilateral action (e.g., Argentina). To compensate procyclical private financing, broader multilateral financial support was also made available (see part IV) but, as we will see, this operated as a secondary factor.

In the case of fiscal policy, the room of maneuver for counter-cyclical policies was also limited by recent fiscal stances, both in relation to the magnitude of inherited public sector debts as well as the rhythm of fiscal expansion during the previous boom. It also depended on the effects that volatile fiscal revenues (particularly those from natural resources) had in the public sector finances of individual countries, and well as on the capacity of domestic bond markets to finance current fiscal imbalances in non-inflationary ways. As we will see, the situation of developing countries was quite mixed in this area.

Aside from these external balance sheet and fiscal considerations, a third set of circumstances affecting the space for counter-cyclical policies was the health of the financial sectors as well as the presence or absence of major currency mismatches in portfolios of private sector agents, particularly but not only of domestic financial institutions - the phenomenon known as "liability dollarization" but that in the European periphery meant liabilities in euros or Swiss francs. The trend is most of the developing world was positive in both regards, as they had strengthened their prudential regulatory and supervisory frameworks after their own financial crises and had experienced a boom in domestic bond markets, which had also helped to reduce currency mismatches. But, as we will see, there were important exceptions. Beyond the vulnerability to domestic financial crises associated with these factors, and again reflecting the procyclical patterns of external financing, dependence of domestic financing on external funding was crucial to avoid a domestic credit crunch.

There were major improvements in all these areas during the 2003-2007 boom. Developing countries' external balance sheets had indeed improved on a fairly broad-based basis. Table 5 
summarizes the evolution of three major external variables during the recent boom -the current account balance, external debt and foreign exchange reserves-in 90 developing and transition economies, ${ }^{9}$ each with a population of over 5 million as of 2007. The table shows the simple averages of ratios of these variables to GDP for each region, as well as the proportion of countries showing improvement in the indicator over the boom.

\begin{tabular}{|c|c|c|c|c|c|c|c|c|c|c|c|}
\hline & \multirow{2}{*}{$\begin{array}{c}\text { Number } \\
\text { of } \\
\text { Countries }\end{array}$} & \multicolumn{4}{|c|}{ Current Account Balance } & \multicolumn{3}{|c|}{ External Debt } & \multicolumn{3}{|c|}{ Foreign Exchange Reserves, excl. gold } \\
\hline & & $\begin{array}{c}\% \text { of GDP } \\
2003\end{array}$ & $\begin{array}{c}\% \text { of GDP } \\
2007\end{array}$ & $\begin{array}{l}\% \text { with } \\
\text { deficit, } 2007\end{array}$ & $\begin{array}{c}\% \text { with } \\
\text { improvement }\end{array}$ & $\begin{array}{c}\% \text { of GDP } \\
2003\end{array}$ & $\begin{array}{l}\% \text { of GDP } \\
2006\end{array}$ & $\begin{array}{l}\text { \%with } \\
\text { improvement }\end{array}$ & $\begin{array}{c}\% \text { of GDP } \\
2003\end{array}$ & $\begin{array}{c}\% \text { of GDP } \\
2007\end{array}$ & $\begin{array}{l}\text { \% with } \\
\text { improvement }\end{array}$ \\
\hline Africa & 31 & -5.6 & -4.2 & $87 \%$ & $45 \%$ & 89.7 & $\frac{200}{43.0}$ & $97 \%$ & $\frac{005}{12.8}$ & 18.1 & $78 \%$ \\
\hline $\begin{array}{l}\text { Aima al and Eastern Europe } \\
\text { Central and }\end{array}$ & 8 & -5.4 & -9.1 & $100 \%$ & $38 \%$ & 56.4 & 57.3 & $57 \%$ & 21.0 & 23.2 & $63 \%$ \\
\hline CIS & 8 & -1.0 & 3.1 & $63 \%$ & $25 \%$ & 56.1 & 44.5 & $88 \%$ & 12.9 & 21.3 & $100 \%$ \\
\hline Asia, incl. NICs & 20 & 2.2 & 3.0 & $30 \%$ & $45 \%$ & 52.6 & 36.9 & $100 \%$ & 27.2 & 32.7 & $69 \%$ \\
\hline Middle East, inc. Egypt & 7 & 7.2 & 6.5 & $43 \%$ & $43 \%$ & 54.0 & 28.6 & $100 \%$ & 41.1 & 50.1 & $40 \%$ \\
\hline Latin America and the Caribbean & 16 & -0.7 & -0.9 & $50 \%$ & $38 \%$ & 63.7 & 37.6 & $100 \%$ & 11.7 & 14.8 & $69 \%$ \\
\hline
\end{tabular}

The dominant pattern over this period was an increasing number of countries with current account (and, in some cases, large size) deficits. In contrast, there were broad-based and generally large improvements in debt ratios, as well as significant foreign exchange reserve accumulation. The latter underestimates the magnitude of the improvement in external balance sheets, as it does not include fiscal funds held abroad by either sovereign wealth or stabilization funds.

In regional terms, the Middle East and Asia show the best performance in the three dimensions, and of all but debt in the CIS. Africa shows large current account deficits but significant improvements in the other two dimensions. The Latin America and the Caribbean region stands out for its historically unprecedented avoidance of current account deficits as well as significant improvements in debt ratios. Central and Eastern Europe shows by far the weakest stance: large current account deficits with limited or no improvements in debt and foreign exchange reserves.

Table 6 confirms this picture, showing the evolution of these three set of indicators for major regions, using IMF regional classifications. Current account surpluses, reserve accumulation and falling external debt ratios were the rule during the boom years in most regions, with some exceptions. The major one was Central and Eastern Europe, which showed large current account deficits, increasing external debts and limited reserve accumulation. As also pointed out, the Middle East also experienced a growing debt ratio despite massive reserve accumulation and current account surpluses. Current account surpluses and reserve accumulation were rather moderate in Latin America relative to most other regions but, as we have already pointed out, they were a break with the region's own past.

\footnotetext{
${ }^{9}$ Comparable information is available for the 90 countries in the case of the current account, for 80 in the case of external debt and 78 for foreign exchange reserves.
} 
Table 6: Debt Ratios, Current Account and Reserve Accumulation by Region, 2002-2009

\begin{tabular}{|c|c|c|c|c|c|c|c|c|c|}
\hline & & 2002 & 2003 & 2004 & 2005 & 2006 & 2007 & 2008 & 2009 \\
\hline \multirow{9}{*}{$\begin{array}{l}\text { External debt } \\
\% \text { GDP }\end{array}$} & Emerging and developing economies & 36.65 & 35.19 & 32.33 & 29.44 & 27.47 & 27.88 & 24.24 & 26.00 \\
\hline & Africa & 60.65 & 52.31 & 44.52 & 34.74 & 26.32 & 25.60 & 22.37 & 25.37 \\
\hline & Africa: Sub-Sahara & 65.93 & 56.11 & 47.78 & 37.34 & 28.51 & 27.92 & 24.52 & 27.85 \\
\hline & Central and eastern Europe & 50.76 & 51.14 & 49.97 & 45.53 & 52.83 & 56.51 & 54.36 & 66.30 \\
\hline & Commonwealth of Independent States & 45.89 & 44.20 & 38.46 & 35.95 & 35.72 & 39.80 & 33.07 & 41.83 \\
\hline & Developing Asia & 25.66 & 23.70 & 22.31 & 20.67 & 19.26 & 17.51 & 15.00 & 15.26 \\
\hline & ASEAN-5 & & & & & & & & \\
\hline & Middle East & 27.95 & 26.57 & 25.96 & 32.95 & 32.90 & 37.34 & 27.82 & 31.00 \\
\hline & Western Hemisphere & 42.36 & 42.12 & 36.69 & 30.10 & 23.97 & 23.00 & 20.54 & 22.12 \\
\hline \multirow{9}{*}{$\begin{array}{l}\text { Current Account } \\
\% \text { GDP }\end{array}$} & Emerging and developing economies & 1.21 & 1.98 & 2.49 & 4.18 & 5.20 & 4.30 & 3.88 & 2.02 \\
\hline & Africa & -1.82 & -0.65 & 0.25 & 1.73 & 5.45 & 2.86 & 2.53 & -3.13 \\
\hline & Africa: Sub-Sahara & -3.93 & -3.06 & -1.72 & -1.15 & 3.03 & 0.24 & 0.19 & -3.73 \\
\hline & Central and eastern Europe & -3.00 & -4.03 & -5.40 & -5.02 & -6.64 & -7.94 & -8.03 & -3.08 \\
\hline & Commonwealth of Independent States* & 6.54 & 6.23 & 8.20 & 8.72 & 7.40 & 4.21 & 4.93 & 2.90 \\
\hline & Developing Asia & 2.52 & 2.82 & 2.65 & 4.16 & 6.09 & 7.03 & 5.90 & 4.99 \\
\hline & ASEAN-5 & 3.67 & 4.03 & 2.88 & 1.96 & 4.78 & 4.94 & 2.63 & 3.35 \\
\hline & Middle East & 4.36 & 7.85 & 11.65 & 19.30 & 20.89 & 18.12 & 18.32 & 2.56 \\
\hline & Western Hemisphere & -0.92 & 0.48 & 1.01 & 1.32 & 1.53 & 0.36 & -0.71 & -0.81 \\
\hline \multirow{9}{*}{$\begin{array}{l}\text { Reserve } \\
\text { Accumulation } \\
\% \text { GDP }\end{array}$} & Emerging and developing economies & 2.30 & 4.00 & 4.72 & 5.04 & 5.67 & 7.94 & 3.62 & 2.05 \\
\hline & Africa & 1.24 & 1.87 & 4.38 & 5.16 & 5.67 & 5.52 & 4.18 & -1.17 \\
\hline & Africa: Sub-Sahara & & & & & & & & \\
\hline & Central and eastern Europe & 1.25 & 1.35 & 1.30 & 3.75 & 2.49 & 2.20 & 0.29 & 0.12 \\
\hline & Commonwealth of Independent States* & 3.26 & 5.71 & 7.08 & 7.68 & 9.82 & 9.87 & -1.51 & -1.26 \\
\hline & Developing Asia & 4.17 & 5.52 & 7.39 & 5.84 & 6.82 & 10.68 & 6.09 & 4.31 \\
\hline & ASEAN-5 & & & & & & & & \\
\hline & Middle East & 2.36 & 6.72 & 5.40 & 10.32 & 10.44 & 13.63 & 8.59 & 2.65 \\
\hline & Western Hemisphere & -0.08 & 1.79 & 1.01 & 1.27 & 1.61 & 3.66 & 1.22 & 0.50 \\
\hline
\end{tabular}

Note: Georgia and Mongolia, which are not members of the CIS, are included for reasons of geography and similarities in economic structure.

Unfortunately, no equivalent picture can be drawn for fiscal indicators. However, for those countries for which data are available, large fiscal deficits were generally infrequent at the onset of the crisis. Again, Central and Eastern Europe and, in this case, major South Asian countries stand out as having the weakest positions, and there were elsewhere individual countries with large central government deficits generally mixed with high levels of public sector debt, such as Egypt and Jordan in the Middle East.

However, although, thanks to these factors, domestic demand policies were more broadly available in the developing world than during previous crises, the policy space to use them was unevenly distributed and, in any case, their potential effect is limited in open economies. As a result, such policies were more powerful in the less open economies, most of which are large ones. For this reason, Brazil, China and India resonate in all discussions as the most successful policies of this kind during the recent crises. Some countries were more reluctant to adopt strong counter-cyclical policies, due to the perception that they could risk downgrades in credit ratings and thus future access to financial markets, or because they meant a reversal of what countries perceived as hard-won achievements, particularly in the fiscal area. Among large developing economies, Mexico and Turkey are examples of relatively mild and lagged counter-cyclical response associated with concerns of this type (see below).

Thanks to improved external balance sheets, the room for monetary policies to compensate for the sudden stop in external financing, using the large foreign exchange reserves in the 
hands of developing countries was broadly available. Monetary policy in most countries did indeed follow the lead of industrial countries in reducing interest rates, though this generally came with a lag of a few months and the magnitude of the reduction was in several cases smaller than those of industrial countries. Central bank credit lines to domestic financial institutions were sometimes made available, but a more common expansionary policy was the reduction in reserve requirements, an instrument that has been largely discontinued in industrial economies but that is still relevant in developing countries. More novel in terms of central bank financing was the use of foreign exchange reserves to compensate for the reduction in external financing, by making credit lines in foreign currency available to exporters and to other private firms with a demand for foreign exchange, including to cover losses in derivative contracts. Central banks also used their accumulated foreign exchange reserves to help stabilize strong depreciation pressures on their currencies, but this was generally mixed with exchange rate flexibility in countries that had been practicing (dirty and, in some case, quite dirty) floating. Brazil was a remarkable case of all these types of central bank interventions (Barbosa, 2010). A strong external balance sheet was the crucial factor making such interventions possible.

These expansionary measures had, in any case, limited effects on domestic demand in the more open economies, and were in some cases counteracted by the worldwide credit crunch in private financing, which was transmitted with intensity to domestic banking sectors in several developing countries. This generated similar situation to that of industrial countries, in which expansionary monetary policies were unable to counteract the private sector credit crunch. Bank financing is, of course, more important in developing than in industrial economies, but even in the latter the recovery in bond financing was not matched by a similar trend in bank financing.

In developing countries, those with dependence of domestic banks on external funding were the most affected. The credit crunches of Central and Eastern Europe as well as the Middle East are a result of this type of dependence (Calvo, 2010). In Latin America, Chile and, to a much lesser extent, Peru are similar cases (ECLAC, 2009). Indeed, Chile is a remarkable case of strong counter-cyclical fiscal and monetary policies that were relatively powerless in the face of both a domestic credit crunch and high trade openness. In contrast to this pattern, and as a paradoxical twist of history, countries that had maintained large public financial sectors were at an advantage to undertake expansionary credit policies and compensate the private sector credit crunch. Brazil, China and India were able to put their public sector banks to support their recovery, and in a particularly aggressive way in the case of China, which started to reverse this policy in early 2010.

Due to the high dependence of their banking sectors on external financing, Russia and several Gulf countries are extraordinary examples of a very peculiar macroeconomic pattern: central banks largely and correctly absorb the excess supply of foreign exchange generated by private external financing during the boom; this implies large social losses, as the costs of private financing are higher than revenues from the investment of reserves; in turn, during the crisis, as capital flights and the domestic credit crunch ensues, the central bank must come to the rescue to supply foreign exchange. In a very peculiar way, central banks from developing countries thus become intermediaries between the private international financial sector and the Treasuries of industrial countries, where their foreign exchange reserves are invested. It should be underscored that, though this phenomenon is particularly marked in those countries 
where domestic banks are dependent on external financing, it is more broadly present in the face of procyclical capital flows, and reappeared with force since the second quarter of 2009.

Domestic financial crises were infrequent during the recent turmoil in developing, including emerging economies. Russia and Nigeria are probably the most important exceptions. In Central and Eastern European countries where banks are largely foreign owned, the crisis was in a sense "exported" to the home countries of the banks, and became therefore part of the broader picture of financial crises in Western Europe. Among these countries, those with flexible exchange rates were also the major cases of currency mismatches in domestic portfolios that generated massive losses when crisis struck and currencies depreciated (as we will see below, those with fixed rates faced other problems). Elsewhere, although this pattern was less frequent than in the past, private sectors in some countries accumulated growing foreign exchange risk during the boom through borrowing abroad or derivative operations. In this case, counteracting the sudden stop in external financing depended heavily on the capacity of central banks to compensate these trends, which was essentially dependent, again, on foreign exchange reserves.

The worst cases, where monetary policy turned indeed overtly procyclical were associated with defense of currency boards, a pattern present in some countries of the European periphery (the Baltic countries and Bulgaria). Attempts by central banks to smooth appreciation pressures by raising interest rates were much less frequent than during past crises, but not entirely absent.

In the area of fiscal policy, responses were very diverse. Perhaps the most important fact to emphasize is that East Asia was by far the most active region. The recent UN's World Economic Situation and Prospects provides summary estimates of fiscal stimulus packages for 55 economies around the world (UN, 2010a, Table I.4). An interesting conclusion is that the largest cluster of highly expansionary fiscal policies was concentrated in East Asia: 7 out of the 13 developing economies' packages worth over 5\% of GDP (China, Thailand, Hong Kong, South Korea, Malaysia, Singapore and Vietnam); ${ }^{10}$ even countries in this region with not particularly strong fiscal positions (such as Cambodia and Laos) joined in this trend. Most South Asian countries also ran strongly expansionary fiscal policies, despite their initial high deficit and debt levels. But otherwise there are significant differences. In Sub-Saharan Africa, for example, Kasakende et al. (2010) indicate that some countries ran very active countercyclical fiscal policies (Kenya, Mauritius, South Africa, Tanzania and Uganda) but not others (Botswana). In Latin America, Chile ran the clearest counter-cyclical fiscal policy, and other countries also had expansions in public sector spending of over 2\% of GDP (Argentina, Costa Rica, Paraguay, Uruguay) but other reduced such spending (Bolivia, Dominican Republic, Ecuador and Venezuela) (ECLAC, 2009, Chapter II). Obviously, the stimulus measures taken in 2009 mean that the space for further counter-cyclical policies has shrunk. This is particularly true in countries with initial public sector debt ratios, with South Asian countries as perhaps the most important example.

The Latin American case actually reflects the quite different performance of economies that are highly dependent on fiscal revenues from natural resources: Chile, on the one hand, which

\footnotetext{
${ }^{10}$ We exclude Honduras, which according to the Table had a large package but indeed did not increase spending as a proportion of GDP according to ECLAC (2009). This case also makes it clear that the definition of the fiscal package may not be uniform, and may reflect policy announcements with political contents rather than effective policies.
} 
saved a significant amount of the windfall fiscal revenues during the boom, vs. three economies that largely spent such windfall revenues (Bolivia, Ecuador and Venezuela). In other parts of the world, savings of such revenues during the boom allowed for large countercyclical spending during the crisis. Two important cases are Kazakhstan and Saudi Arabia, the two countries that competed with China as having the largest fiscal packages during the crisis according to the aforementioned UN report. Equally important, as most developing countries were expanding public sector spending at rapid rates during the boom, the expansionary effect of fiscal may have actually declined relative to the boom years even if fiscal spending continued increasing during the crisis. This is indeed the average performance of Latin America, where fiscal policy had generally been expansionary during the boom (Ocampo, 2009) and government consumption actually generated a stronger expansionary effect up to the third quarter of 2008 than thereafter (see ECLAC, 2009, Figure I.11).

The picture that emerges is, therefore, one in which developing countries did have larger room for maneuver to adopt counter-cyclical policies than in the past, thanks particularly to their improved external balance sheets. The major regional exception was Central and Eastern Europe, where the traditional mix of weak external and fiscal indicators and domestic financing highly dependent on external funding still prevailed, a combination that, as in the past, generated significant vulnerabilities in the face of the dramatic shock experienced during the global financial crisis. More generally, however, and again with some exceptions, even those developing countries that had more limited space to adopt counter-cyclical policies or were unwilling to use the space they had, they generally enjoyed this time the capacity to avoid the traditional pro-cyclical macroeconomic policies that were typical of past crises. Avoidance of high domestic interest rates was, in turn, one factor contributing to the relative absence of banking crises this time.

\section{2.- PERFORMANCE: A GENERAL LOOK}

Despite their strength and the greater frequency of counter-cyclical policies, the shock was severe almost everywhere. One striking way to summarize the available information is noticing that 73 out of the 125 developing and transition economies for which the UN provides data experienced a reduction in per capita GDP in 2009 vs. only 11 in 2007. In turn, only 13 had per capita GDP growth of over 3\% in 2009, the threshold identified by the UN as that necessary to achieve large reductions in poverty, vs. 86 economies in 2007 (UN, 2010a, Table I.2).

Table 7 summarizes the performance of developing and transition economies vs. industrial countries, both in terms of performance in 2009 as well as the magnitude of the slowdown vis-à-vis the boom years 2003-2007, according to UN estimates and regional breakdown. Several issues are worth emphasizing. The first is that the worst performance by far was that of the transition economies and of the CIS in particular, both in terms of contraction of GDP in 2009 as well as the slowdown from the boom years: a striking 14 percentage points! The transition economies that are members of the European Union (all new members excluding Malta and Cyprus) show the second strongest slowdowns, though the contraction in 2009 is not as bad thanks to the growth of Poland, the largest among them. 
Table 7: Growth of Developing and Emerging Economies

\begin{tabular}{|c|c|c|c|c|c|}
\hline & $\begin{array}{c}\text { Average } \\
2003-2007\end{array}$ & 2008 & 2009 & $2010^{* *}$ & 2009 vs. $2003-07$ \\
\hline Developed economies & 2.71 & 0.41 & -3.42 & 1.90 & -6.13 \\
\hline Developing countries* & 7.16 & 5.34 & 2.24 & 5.88 & -4.92 \\
\hline Africa & 5.87 & 4.95 & 2.45 & 4.70 & -3.42 \\
\hline North Africa & 5.09 & 4.91 & 3.58 & 4.63 & -1.51 \\
\hline Sub-Saharan Africa (excluding Nigeria and South Africa) & 6.99 & 6.16 & 2.85 & 5.56 & -4.15 \\
\hline East and South Asia & 8.32 & 6.22 & 4.77 & 7.15 & -3.56 \\
\hline East Asia & 8.42 & 6.14 & 4.69 & 7.31 & -3.74 \\
\hline China & 11.29 & 9.01 & 8.70 & 9.20 & -2.59 \\
\hline East Asia (excluding China) & 5.62 & 2.96 & -0.04 & 4.90 & -5.66 \\
\hline South Asia & 7.97 & 6.49 & 5.06 & 6.54 & -2.91 \\
\hline India & 9.02 & 7.29 & 6.40 & 7.90 & -2.62 \\
\hline South Asia (excluding India) & 5.92 & 4.82 & 2.21 & 3.54 & -3.71 \\
\hline Western Asia & 6.57 & 4.33 & -1.05 & 4.16 & -7.62 \\
\hline Western Asia (excluding Israel and Turkey) & 6.35 & 6.62 & 0.90 & 4.76 & -5.45 \\
\hline Latin America and the Caribbean & 5.42 & 3.97 & -2.12 & 4.03 & -7.54 \\
\hline South America & 6.08 & 5.26 & -0.29 & 4.45 & -6.37 \\
\hline Mexico and Central America & 4.10 & 1.69 & -5.89 & 3.41 & -10.00 \\
\hline Caribbean & 7.12 & 3.82 & 0.99 & 2.49 & -6.13 \\
\hline Economies in transition & 7.60 & 5.36 & -6.66 & 3.95 & -14.26 \\
\hline South-eastern Europe & 5.39 & 4.27 & -3.67 & 1.13 & -9.06 \\
\hline Commonwealth of Independent States & 7.81 & 5.49 & -6.95 & 4.23 & -14.76 \\
\hline New EU member States & 5.73 & 3.94 & -3.55 & 1.72 & -9.28 \\
\hline \multicolumn{6}{|l|}{ Memorandum items: } \\
\hline Least developed countries & 7.95 & 7.07 & 3.98 & 5.56 & -3.98 \\
\hline
\end{tabular}

The developing countries as a whole experienced moderate growth and a weaker slowdown than the industrial world, but this aggregate figure is biased by the good performance of the two Asian giants. Another and perhaps the most positive outcome from the point of view of meeting the MDGs was that the least developed countries experienced a better performance than the average for the developing world (3.3\%), with the performance of the largest of them (Bangladesh) being particularly positive. This is furthermore consistent with the fact that the two regions with the highest incidence of extreme poverty, Sub-Saharan Africa and South Asia had also a better than average performance, with South Asia being indeed the best performing region of the world. Among the regions with a large share of middle-income countries, North Africa did best, while East Asia excluding China, Western Asia (largely due to the strong Turkish recession) and Latin America (largely affected, in turn, by the very poor performance of Mexico) did worst. The worst performing individual countries tended to cluster in the transition economies and the latter regions. The worst performing economies belong indeed to these developing country regions (Hong Kong, Taiwan, Singapore, Turkey and Mexico) or are transition economies (the three Baltic countries, Russia and Ukraine), though a few belong to others (Botswana, a mineral economy, being the most important example).

The worst performing countries and regions have two entirely different features. In the case of the transition economies, the dominant feature is the presence of the traditional macroeconomic and financial vulnerabilities emphasized above. In the case of the developing 
countries, it was high dependence on manufacturing exports. In this regard, it is interesting to see the average performance of different developing countries according to dominant specialization patterns (according to measures of revealed comparative advantage). As emphasized by Ocampo et al. (2009, ch. 4), among others, there has been a clear long-term growth performance of economies with export patterns dominated by high and mediumtechnological content, though this pattern is weaker or absent during periods of booming commodity prices. Consistent with the latter observation, growth was quite similar for different specialization patterns during the 2003-2007 boom (see Table 8). Interestingly, however, high and mid-tech exporters suffered more heavily from the collapse of international trade during the Great Recession, while exporters of commodities, natural resource intensive and low-tech manufactures performed on average much better.

Table 8: Average Growth Rate According to Specialization Patterns (Unweighted Averages)

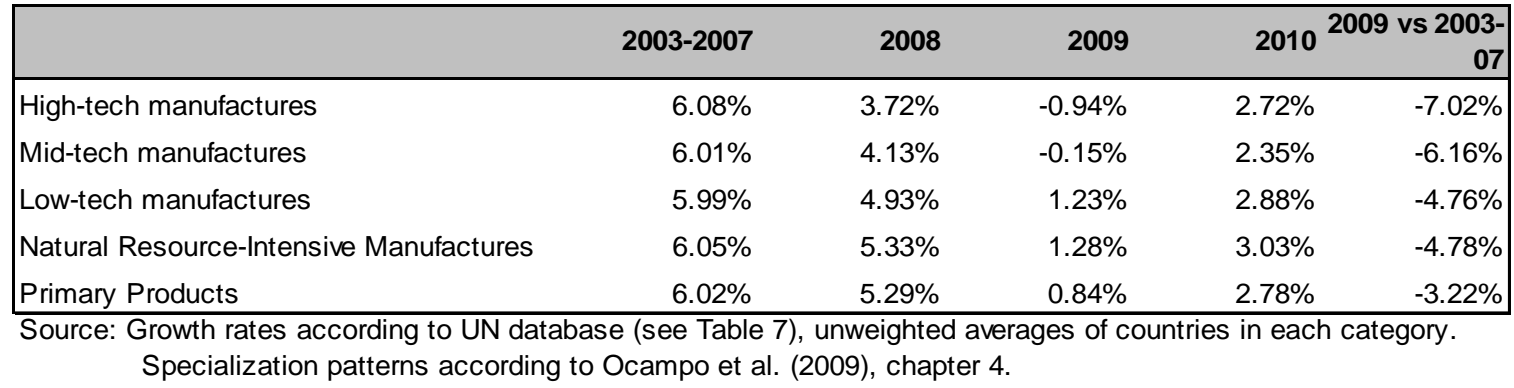

The crisis was obviously reflected in employment conditions and poverty. However, initial fears of dramatic effects of the crisis did not materialize. There were, of course, major job losses in manufacturing export sectors throughout the developing world. There were also rises in unemployment, as well as in informality -vulnerable employment in current ILO terminology - , a much more important problem in developing countries, and again workers who moved into the informal sector would have a hard time getting out of it. But, while we have no reliable information on the magnitude of the rise in vulnerable employment, large increases in unemployment in the developing and emerging economies were concentrated in Central and Eastern Europe and in some Latin American countries (ILO, 2010; UN, 2010a). Past crisis indicate that employment conditions tend to normalize with a longer lag than economic activity. But, given the greater damage inflicted by the crisis on employment conditions in industrial than in developing countries, ILO (2009) estimates that it would take up to five and a half years for labor market conditions to normalize in industrial countries (late 2013) but only two and a half years in developing countries (by the end of 2010). Nonetheless, employment losses in manufacturing export sectors may prove harder to recover, particularly if international trade remains depressed.

Similarly, the crisis undoubtedly slowed down the fairly rapid improvement in poverty levels that had been taking place before the crisis. So, according to UN (2010, Table I.3), the crisis generated 84 million additional extreme poor (under US\$1.25 a day) over the trajectory that would have prevailed according to 2003-2007 trends, an additional poverty incidence of $1.5 \%$. This is roughly consistent with World Bank (2010a) estimates, according to which there would be 64 million additional poor by 2010 if the crisis had not taken place. It is important to emphasize, however, that ILO estimates are much less optimistic, and indicate that there was probably a sharp increase in the number of working poor, indeed erasing over the past two years the gains that had been obtained during the previous boom in most regions. 
This includes regions where the GDP effects of the crisis was not very strong, such as South Asia, Sub-Saharan Africa and North Africa, which according to the ILO experienced, nonetheless, an important increase in vulnerable employment and, in the first two case, have a significant number of working poor just above the poverty lines. Indeed, the only two regions where the reversal has not taken place, according to ILO, are East Asia and Latin America (see Figure 7). It must be emphasized, however, that due to insufficient information, ILO estimates on the number of working poor has a high variance.

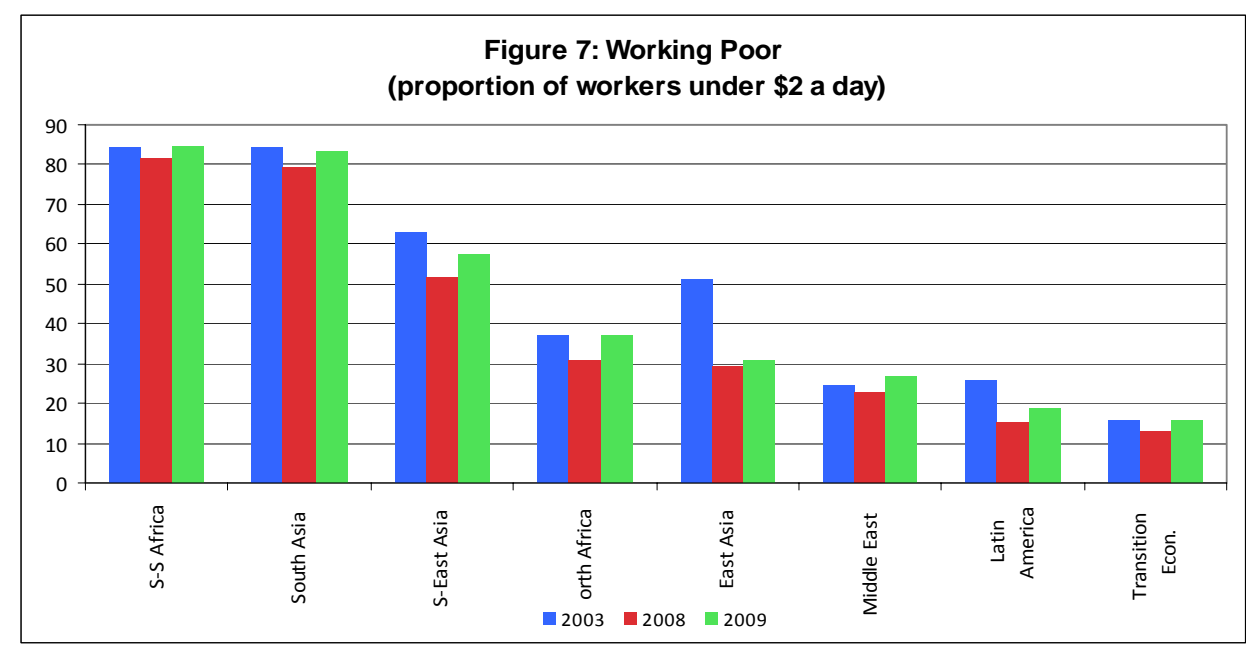

Source: ILO (2010).

The UN and World Bank estimates of additional extreme poverty are small magnitudes that would not significantly change expectations of reaching the objective set in the MDGs of reducing 1990 extreme poverty levels by half by 2015. According to current projections (Table 9), this objective would be reached for the world as a whole and most regions, but it would not be met for Sub-Saharan Africa. In any case, according to these projections, the pace of reduction of the proportion of people below US\$2 a day is slower, particularly in the two poorest regions of the world. Obviously, were the world economy to face a double-dip recession or a longer period of slow economic growth, the trajectory of poverty reduction might be affected in a stronger way. Reduced ODA (see section IV.2 below) indicates that other MDGs targets may be affected. 
Table 9: Poverty in Developing Countries by Region

\begin{tabular}{|c|c|c|c|}
\hline Regions or Countries & 1990 & 2005 & 2015 \\
\hline \multicolumn{4}{|c|}{ Percentage of the population living on less than $\$ 1.25 /$ day } \\
\hline East Asia and the Pacific & 54.7 & 16.8 & 5.9 \\
\hline China & 60.2 & 15.9 & 5.1 \\
\hline Europe and Central Asia & 2.0 & 3.7 & 1.7 \\
\hline Latin America and the Caribbean & 11.3 & 8.2 & 5.0 \\
\hline Middle East and North Africa & 4.3 & 3.6 & 1.8 \\
\hline South Asia & 51.7 & 40.3 & 22.8 \\
\hline India & 51.3 & 41.6 & 20.3 \\
\hline Sub Saharan Africa & 57.6 & 50.9 & 38.0 \\
\hline Total & 41.7 & 25.2 & 15.0 \\
\hline \multicolumn{4}{|c|}{ Percentage of the population living on less than $\$ 2.00 /$ day } \\
\hline East Asia and the Pacific & 79.8 & 38.7 & 19.4 \\
\hline China & 84.6 & 36.3 & 16.0 \\
\hline Europe and Central Asia & 6.9 & 8.9 & 5.0 \\
\hline Latin America and the Caribbean & 19.7 & 16.6 & 11.1 \\
\hline Middle East and North Africa & 19.7 & 16.9 & 8.3 \\
\hline South Asia & 82.7 & 73.9 & 57.0 \\
\hline India & 82.6 & 75.6 & 58.3 \\
\hline Sub Saharan Africa & 76.2 & 73.0 & 59.6 \\
\hline Total & 63.2 & 47.0 & 33.7 \\
\hline
\end{tabular}

\section{3.- REGIONAL PERFORMANCE}

The Asian financial crisis of the late 1990s and the response to that crisis by international capital markets and official agencies, notably the US Treasury and the IMF, continued to reverberate during the boom years that followed and during the global financial crisis itself. The heavy price that many East Asian economies paid for the pro-cyclicality of finance and of the policy conditions on which international assistance was provided, arguably contributed to the emergence of the Great Recession -through massive "self-insurance" in this region, a factor in the build up of global imbalances. It also prevented, however, the recession from turning into another Great Depression -as massive reserve accumulation provided this time ample space for active and large counter-cyclical macroeconomic policies in East Asia.

Whilst there is universal agreement that East Asia led by China is leading the recovery of the world economy, there is a particularly pronounced and often confusing difference in the array of estimates of growth trends in what is called "East Asia" in documents of various international organizations: 4.1\% growth in 2009 according to the UN regional breakdown shown in Table 7 vs. 6.8\% according to World Bank. ${ }^{11}$ The major difference is the exclusion by the World Bank of the "high-income" Asian economies of Hong Kong, Singapore, South Korea and Taiwan all of which went into a recession in 2009.

\footnotetext{
${ }^{11}$ IMF estimates are in turn biased by the use of PPP estimates (see footnote 2 above).
} 
Given the very high level of integration of the region into the global economy, East Asia was affected early and substantially by the recession, particularly through sharp falls in trade and industrial production between September 2008 and March 2009; China shared the trade recession but was able to avoid a contraction of industrial production. However, massive counter-cyclical macroeconomic fiscal, monetary and credit policies helped turn this region into the major engine of world economic recovery since the second quarter of 2009, propelling also an impressive rebound of financial markets (stock exchanges, bond issuance and IPOs, though not syndicated loans). Given its large domestic market and smaller ratio of trade to GDP, these policies were more effective in China, but aggressive expansionary fiscal and monetary policies in the rest of the region also contributed to the recovery. This led to some large fiscal deficits in some economies, with Vietnam (9.4\% of GDP) and Malaysia (7.8\%) leading the way. Growing regional trade integration in recent years also helped the recovery to speedily spread from one country to another. For the year as a whole, most countries experienced a recession. Aside from China, Indonesia and Vietnam proved particularly resilient. Excluding China, growth averaged just $1.3 \%$ in the rest of East Asia on the World Bank definition and was negative $(-0.8 \%)$ on the UN definition (see Table 7 above).

Chinese policies included a massive fiscal package for 2009 and 2010 announced very early on, in November 2008, equivalent to some $14 \%$ of GDP. This implied a $22.1 \%$ increase in total government expenditures (central plus local) in 2009, though only a modest fiscal deficit of a little over 3\% of GDP. Given excess capacity in the industrial sector, much of the stimulus package was directed at investment in infrastructure. It was accompanied by massive credit expansion and a highly expansionary monetary policy, essentially a sharp stop in the issuance of central bank bills that had been used in previous years to sterilize the massive accumulation of foreign exchange reserves (Yu, 2010). Fears that this aggressive policy would lead to asset price bubbles, especially in housing, led authorities to adopt policies to limit the growth of domestic lending in early 2010.

As we have already noticed, South Asia was the best performing region in the world. India served as the second locomotive after China for containing the global recession. Excluding India, South Asia's average growth rate in 2009 was 2.3\% according to the UN data, which include Iran, and 4.4\% according to the World Bank, which do not. Aside from India, Bangladesh, the largest least developed country, was also resilient and continued to grow relatively fast, at over 5\% a year; Nepal, another least developed country in the region, also grew, though at a lower rate. By and large, countries in this region have been very measured in both their trade and financial liberalization and hence with their integration into the world economy. Capital accounts and financial sectors have been regulated with caution and with wariness about exposing them to the pro-cyclicality of financial markets. Though inflation has been modest, fiscal positions have tended to be weak, financed for the most part with domestic non-bank borrowing (especially India) and usually concessional or long-term external financing (especially in Bangladesh). This is also the region most dependent on remittances (again with the exception of Iran) from the Gulf countries, which were relatively resilient during the crisis.

For all these factors, this was the region most likely to resist the exogenous shocks that the global financial crisis generated. Nonetheless, growth did slow down sharply and active counter-cyclical macroeconomic policies had to be employed to prevent a greater collapse. This is particularly true of India but also of Bangladesh and Sri Lanka. It took the form of 
steep reduction in interest rates as well as expansionary fiscal policies. India's stubbornly high fiscal deficits, in the vicinity of 9-10\% of GDP for much of the 1990s and early 2000s had begun to decline to closer to $6 \%$ before the crisis hit. The counter-cyclical measures adopted led to a reversal of this trend and the deficit is back to around $10 \%$. It began to withdraw this fiscal stimulus in early 2010, though its monetary polices are likely to remain expansionary.

Pakistan is a notable exception to these trends as its macroeconomic balances had deteriorated seriously in the couple of years leading to the global crisis, leaving it no room for countercyclical policies when the crisis hit, and had to resort to the IMF for support. But even this country maintained a positive rate of growth (though barely in per capita terms). Sri Lanka, the most open economy in the region and, as in Pakistan, with a domestic conflict and an IMF program, also slowed down but remained in the positive territory.

As a region, Africa came third after East and South Asia in terms of growth. This average includes the fair performance of both North Africa and Sub-Saharan Africa, though in the latter case with an average decline in per capita incomes given rapid population growth. North Africa's fair performance reflected in part bumper harvests in Algeria and Morocco, as well as fiscal stimuli in Egypt, Morocco and Tunisia that focused mainly on public investment in infrastructure. The stimulus package in Morocco also included state guarantees for credit to leading export industries and in Egypt a significant easing of monetary policy. Morocco and Egypt were amongst the hardest hit countries by falling remittances, and Tunisia, Morocco and Egypt by decline in tourism, reflecting in all these cases the transmission of the European crisis.

The fall in per capita incomes in Sub-Saharan Africa was the first in about a decade and brought to an end the recovery from the most prolonged economic decline that any developing region has experienced since records began -a period we referred to above as a "lost quarter century". ${ }^{12}$ The rapid growth had reflected above all booming commodity prices and debt write-offs, with some support from growing official development assistance, rising remittances and FDI in extractive industries, and much less private financial flows. The extent to which policy reforms also contributed and in what particular way remains a matter of controversy. ${ }^{13}$ Go and Page (2008, pp. 2-3) address the issue of the extent to which the growth spurt commencing in the late 1990s can be attributed to positive exogenous shocks and to policy reforms arguing that whilst booming export prices helped, "growth acceleration ....is due not only to favorable terms of trade, but also better policy.... Nonetheless, the sustainability of that growth is fragile because economic fundamentals such as savings, investment, productivity, and export diversification remain stagnant.”

Improved macroeconomic management and exchange rate policies meant, in particular, that both the fiscal and the foreign exchange positions of most countries in Sub-Saharan Africa were much better than in previous global crises. This provided the space for several countries to pursue counter-cyclical monetary and fiscal policies, with significant exceptions (Kasekende et al., 2010; IMF, 2009c). IMF advice and conditionality also exhibited a welcome turn around from their previous pro-cyclical bias. As a result of all these factors, the

\footnotetext{
${ }^{12}$ Over the decade and a half ending in the mid-1990s incomes fell to such an extent that despite reasonably robust growth approaching $5 \%$ a year on average in the latter part of the 1990s, SSA's per capita income by 2000 was roughly at the same level as in 1970. It was not though all doom and gloom, as SSA also included the fastest growing country in the world during 1960-2000: Botswana.

${ }^{13}$ See, for example, the contributions from Noman et al. (2010).
} 
effects of the Great Recession on Africa were less pronounced than during past crises. Out of 43 SSA countries for which the World Bank (2010a, Table A-12) presents data, only 12 experienced a decline in per capita GDP (half of them an absolute fall).

Like other developing regions, the intensity and relative importance of the trade, finance and remittance shocks varied across different countries according to their individual circumstances, in particular, the degree and pattern of integration into the world economy. In the trade area, terms of trade shocks were more important than falling volumes, with agricultural exporters facing a weaker shock than oil and mineral exporters. The decline in exports not only affected the current account of the balance of payments but also dampened budgetary revenues and widened fiscal deficits. The worst affected were the middle income economies because of their greater global integration, especially in financial markets, with oil-exporters also experiencing particularly sharp growth decelerations. Sub-Saharan Africa's biggest economy, South Africa, suffered an absolute decline, notwithstanding the adoption of an important fiscal stimulus package, leading the sub-region of Southern Africa to experience the worst regional performance (-1.7\% growth). West Africa's GDP growth slowed sharply but at $2.4 \%$ slightly outpaced population growth. In Nigeria, the region's second largest economy, agriculture more than offset the decline in industrial and oil production. East Africa's growth of 3.8\% was the fastest amongst SSA's sub-regions, reflecting above all the continuing dynamism of Ethiopia (at $7.2 \%$ it was the fastest growing economy in SSA in 2009, as it had been the second in the preceding three years, after Angola, where growth was oil-led).

The remaining regions in the developing world experienced a contraction of GDP. In the case of Western Asia, this reflects above all the steep Turkish recession. Indeed, excluding this country and Israel (which is included in this group by the UN and experienced a moderate recession), the region posted small positive growth. In Turkey, dependence on foreign capital flows combined with a high initial current account deficit proved pretty devastating in an environment characterized by the world financial crisis and a collapse of world trade, in this particular case imports from Western Europe. In this context, counter-cyclical policies were undertaken, though with a lag that reflected the initial fears of inflation and reversing hardwon fiscal gains from earlier in the decade (Özatay, 2010; Uygur, 2010). In the Gulf countries, the dominant factor was the credit crunch generated by high dependence of the banking system on external funding (Calvo, 2010). This factor, together with cuts in OPEC oil quotas, had negative effects on the Gulf countries, but they were compensated by very expansionary fiscal policies, which operated as the main engine of demand expansion. In turn, the resilience of migration flows from the Gulf countries helped non-oil countries in the region weather the storm (as well as South Asia). However, there are fresh concerns in the light of Dubai World's crisis in late 2009 about the slowing down of the construction sector led boom and hence of remittances.

Latin America was, no doubt, better prepared than in the past to face the financial shock, thanks to improved external balance sheets and fiscal accounts. However, macroeconomic policies during the boom, and particularly fiscal spending, had been pro-cyclical in most countries; also, and although current accounts were in the positive territory until 2007, this hides the fact that countries were spending the windfall generated by high commodity prices and the underlying current accounts were in fact deteriorating (Inter-American Development Bank, 2008; Ocampo, 2009). In some cases, particularly of economies that had been running very expansionary fiscal policies and are highly dependent on natural resources for their fiscal 
revenues, fiscal policy turned contractionary in 2009 (Bolivia, Ecuador and Venezuela). On average, however, countries kept the public spending machine running, or even speeded it up based on discretionary decisions or following explicit counter-cyclical fiscal rules, particularly in the case of Chile (Ffrench-Davis, 2010).

Monetary policies also became expansionary, and in some cases highly so, based on reduction of central bank interest rates and reserve requirements, but generally with a lag, given the fears that had been generated early in 2008 by rising inflation due to the food price shock. So, in general, monetary policies became expansionary only since January 2009 (Colombia was the first to take important steps in December 2008). As indicated above, in the case of Chile and some other countries, expansionary monetary policies were unable to compensate for the credit crunch generated by dependence of domestic credit on external funding.

Dependence on exports of more manufactured goods and some services (tourism), especially to the US, as well as remittances amplified the impact of the crisis in the Northern part of the region, whereas in South America the commodity price collapse had stronger effects. In a sense, as Ocampo (2009) has argued, and thanks to its better financial strength, this was in Latin America more a trade than a financial crisis. Among the largest economies, only Peru had small positive growth; ${ }^{14}$ most small economies in Central America and the Caribbean also experienced a contraction, though one of the small South American economies, Bolivia, had the best regional performance. The most interesting in this region is, in any case, the contrast between the patterns of the two largest economies: Brazil and Mexico. The first adopted an East-Asia type aggressive expansionary package, which included fiscal expansion (though more moderate than in East Asia) and aggressive monetary and credit policies, including large injections of credit in foreign currency through the central bank and of domestic credit through the public sector banks (Barbosa, 2010). In contrast, in Mexico, there was backtracking during 2009 on the initially moderately expansionary fiscal policy, for fears of credit rating downgrades, and although monetary policy followed with a lag that of the U.S. Fed, it lacked the very aggressive expansionary credit policies of Brazil.

The last two regional groups, which comprise the transition economies of Central and Eastern Europe and Central Asia were the most vulnerable to the financial crisis; one might even call them the "models of vulnerability" to such a crisis, in a sense reminiscent of Latin American patterns in the past. These were the countries characterized by domestic financial sectors highly dependent on foreign capital flows, elevated levels of debt (especially external debt), highly trade-dependent, in many cases limited or no exchange rate flexibility and substantial currency mismatches in both corporate and household balance sheets. The prime examples are the three Baltic countries which collectively experienced a catastrophic collapse in GDP (an average of $-15 \%)$.

Among the transition economies that are members of the European Union, only Poland experienced moderate growth, thanks to lower dependence of its banking sector on external funding, relatively lower dependence on exports and the resilience of its agriculture and services sectors. The heavy reliance of the banking sector (made up mainly of foreign banks) in several of these countries on foreign capital flows, paralyzed domestic financing as the

\footnotetext{
${ }^{14}$ Argentina is a subject of considerable controversy, as private analysts, World Bank and IMF indicate that it experienced a recession, but official figures show a small expansion. According to private analysts in the country, this is a reflection of manipulation of the official statistics.
} 
flows were reversed and non-performing loans shot up. They were to some extent victims but also, given their heavy dependence on Western European banks operating in their countries, significant protagonists of the banking crisis of Western Europe. Many of these countries were also severely constrained in their ability to pursue counter-cyclical policies by their desire to join the euro zone, and thus the fiscal and exchange rate targets that that entails, or the currency boards anchored in the euro. Also some countries (e.g. Hungary and Latvia) were subjected to pro-cyclical conditionality for financial assistance from the EU and the IMF.

The remaining transition economies, and particularly the CIS countries, experienced the worst performance of any region in the developing world, dominated by steep contractions in the two largest economies, Russia and Ukraine. Many of these countries also shared the vulnerabilities of the new EU member states, emanating from the nexus of very high reliance on private foreign capital inflows, large current account deficits and external debt as well as currency mismatches. Several, such as Russia, Kazakhstan and Ukraine were also hit by sharp declines in the prices of oil and metals. The deep crisis of Russia was also transmitted to several CIS countries through trade and remittances from migrants residing in that country.

The combination of pro-cyclicality of foreign capital flows and falling oil prices overwhelmed the effects of the stimulus provided in Russia, which was reflected in a sharp change in the fiscal balance from a surplus of 4.3\% of GDP in 2008 to a deficit of $7 \%$ in 2009, as well as repeated cuts in central bank interest rates, which were brought down to effectively zero in real terms. Ukraine, along with the Baltic countries and Iceland experienced the worst economic collapses in the world. In Ukraine, political tensions and the related halting implementation of an IMF program and consequent postponement of the release of a large tranche contributed to this outcome. Some of the small, lower-income economies fared somewhat better, thanks in some cases to less integration into the global economy or through counter-cyclical policies supported by the IMF. As in the case of several of the transition economies members of the European Union, an explicit or implicit peg to the euro became a constraint on monetary easing in most of South Eastern Europe, with Serbia as the major exception. 


\section{Official financing}

The crisis generated a strong response in terms of increased official financing for developing and transition economies. Nonetheless, this response, which was led by the G-20, had a significant bias towards IMF funding, on the one hand, and towards middle-income countries, on the other, with many manifestations. ${ }^{15}$ It was reflected, first, in the allocation of IMF Special Drawing Rights, the single largest response to the crises, low-income countries received only about a fifth of that given to developing countries, which represented slightly less than $40 \%$ of the overall allocation (US\$250 billion). Secondly, and as we will see below, only a fairly modest amount of increased lending by the International Financial Institutions (IFIs) benefited these countries. Third, and crucially, official development assistance (ODA) fell, essentially as a result of the contraction in the Gross National Income (GNI) of industrial countries, which serves as the basis for existing commitments. The low-income countries were, therefore, the Cinderellas of the G-20 response to the crisis!

Though, from the point of view of broader development objectives, it was important to increase support to middle-income countries, given their weight in the world economy as well as the large number of poor people who live in them, it was even more important to increase support to low-income countries, who face significantly more challenges in achieving the MDGs. The fact that the G-20 have taken far less significant initiatives for low income countries may relate, in turn, to their lack of representation in the G-20 itself -we could add, one of the problems that this ad hoc mechanism of representation faces.

Another major problem was that increased lending by IFIs was dwarfed by the massive scale of fall in private flows described in Section II.2. Therefore, the counter-cyclical role of IFIs, though valuable, was insufficient. In fact, if we turn back to Table 3, it can be seen that net official financing in 2009 was only US\$50 billion, only about $15 \%$ of the of net private financial outflows (-US\$331 billion). As that table indicates, though, net official flows were relatively more important in the most affected regions, the two regions dominated by transition economies, as well as to Latin America and the Caribbean and Africa. But even then, it represented a net flow of slightly under US $\$ 100$ billion, only about half the amount of net private financial outflows from these regions in 2009. In the critical months following the Lehman collapse, the problems were, of course, even worse.

Here, we look first at IMF financing and then turn to development financing, both ODA and that provided by Multilateral Development Banks (MDBs).

\section{1.- IMF FACILITIES AND LENDING}

In recent decades, there have been two types of debates on IMF financing. The first is whether its facilities are appropriate or not for current conditions of the world economy. Although this issue involves a large set of questions, we concentrate our attention on financing to manage

\footnotetext{
${ }^{15}$ It can be argued, of course, that middle-income countries as a group are much larger than low-income countries (some 16 times larger according to World Bank definitions, and 12 times if we exclude China from the former group).
} 
external shocks, particularly those associated with capital account volatility and adverse terms of trade movements. The second is the reach of the conditionality attached to its programs. ${ }^{16}$

Capital-account liberalization and capital-account volatility, particular strong pro-cyclical patterns in capital flows to developing and emerging economies, greatly increased the need for official liquidity to deal with large reversals in capital flows. To address these needs, the IMF made efforts to improve its lending policies during the Asian crisis, particularly by establishing in 1997 the Supplemental Reserve Facility (SRF). The evidence that even countries with good macroeconomic fundamentals might be subject to sudden stops of external financing also gave broad support to the idea that a precautionary financial arrangement, closer to the lender-of-last-resort functions of central banks had to be added to the IMF facilities. In 1999, it therefore introduced the Contingent Credit Line (CCL). This facility was never used and was discontinued in November 2003. Since its expiration, the IMF started to explore other ways to achieve its basic objectives. The Medium-Term Strategy of the IMF thus included a provision for a continued dialogue on a mechanism of contingency financing (IMF, 2005).

Managing terms of trade shocks had been, in turn, a major issue since early in the history of the IMF. For this purpose, the Compensatory Financing Facility (CFF) was created in 1963. CFF was meant to be a relatively low conditionality facility and give access to countries to substantial resources relative to countries' quotas and to the size of the shock. It became a major tool of IMF financing in the context of the adverse shocks that oil importing developing countries faced in 1970s, indeed representing close to half of IMF lending in the second half of that decade. However, as a result of increased conditionality for the use of this facility, it was only infrequently demanded since 1990 and ceased to be used since 2000. Since the creation in 1999 of the Poverty Reduction and Growth Facility (PRGF), augmentation of PRGF has been the main vehicle the Fund has used to provide financing for low-income countries hit by shocks, but has represented a relatively low proportion of funding to these countries.

Debates on IMF conditionality are old, but became frontal with the growing scope of the structural conditionality attached to lending in the 1980s and 1990s, particularly after the Asian crisis. ${ }^{17}$ Critics underscored the fact that its macroeconomic policy conditions tended to be pro-cyclical and thus enhanced rather than mitigated the effects of external crises, and that the conditions were rigid and not tailored for the country's specific characteristics. Critics also emphasized the fact that IMF programs included structural conditions on economic liberalization that reflected orthodox views on economic reforms, the effects of which were controversial and were excessively intrusive on domestic decision making processes in developing countries. They thus violated the principle of "ownership" of policies by countries that is now widely recognized as a precondition for policies to be effective, and which by the 1990s the IMF had accepted in principle. Furthermore, many critics also underscored the fact that those conditions often reflected pressures from influential countries on what they wanted specific borrowing countries to do (e.g., opening up their financial sectors to foreign investment, particularly during the Asian crisis).

\footnotetext{
${ }^{16}$ For earlier debates on these issues, see Griffith-Jones and Ocampo (2003 and 2008) and Ocampo and Griffith-Jones (2008).

${ }^{17}$ The best known are those expressed by Stiglitz (2002).
} 
As a result of these pressures, in the late 1990s the IMF began to reconsider the fiscal and structural conditions attached to its programs. In September 2002 the IMF's Executive Board approved a new set of guidelines with a clear intention to streamline conditionality. The new guidelines emphasized the need for member countries' ownership of the policies supported by the Fund and introduced the requirement that structural conditions be "macro-relevant". Guidelines stipulated that conditions must be "critical to the achievement of program goals", and should thus be "flexible and responsive in discussing alternative policies with countries requesting financial assistance” (IMF, 2002).

Further efforts were made in 2005, 2006, and in 2008 along the same lines. In 2005, IMF's Executive Board reviewed the application of the new guidelines and concluded that substantial progress had been made. However, in 2008 the IMF's Independent Evaluation Office (IMF-IEO) completed an assessment of structural conditionality in IMF-supported programs. The report highlighted that conditionality needed to be even more focused and relevant. A new plan in May 2008 called for sharpening the application of the 2002 Guidelines on conditionality by requiring better justification of criticality, establishing explicit links between goals, strategies and conditionality, and enhancing program documents.

There were at the time open debates about whether or not conditionality was in fact being streamlined. Whereas Abdildina and Jaramillo-Vallejo (2005) found evidence that the average number of conditions had declined in recent arrangements, Killick (2005) found that there was no reduction in the number of conditions in programs for low-income countries and that reliance on conditionality remained high. The IMF-IEO evaluation gave an in-depth numerical analysis of conditionality over time and across sectors. Reviewing the entire lending operations of the Fund between 1995 and 2004, it found that IMF programs, for both middle- and low-income countries, had an average of 17 structural conditions, and found no statistically significant difference in the number of structural conditions after the IMF approved its new conditionality guidelines in 2002. In Poverty Reduction and Growth Facility (PRGF) arrangements, the average number of conditions declined from around 16 to 15, while in Stand-By Arrangements (SBAs) they rose from 18 to 19.

The report concluded that conditionality had "shifted out of privatization of state-owned enterprises and trade reform toward tax policy and administration, public expenditure management, and financial sector reform -IMF core areas -." Therefore, the IMF moved away from controversial areas where it had little impact and that largely fall within the World Bank's areas of expertise (and debates on its own conditionality). IMF-IEO's conclusion was that the streamlining initiative did not reduce the volume of conditionality, partly because structural conditions continued to be used to monitor other initiatives such as donors' support programs and the European Union (EU) accession process. Also, in some cases, members of country economic teams requested specific conditionality to help them leverage their domestic policy goals. Even though the number of conditions did not decline significantly, it was highlighted that the bulk of structural conditions had only limited structural depth: more than 40 percent of them called for preparing plans or drafting legislation and about half called for one-off easily reversible changes.

The global financial crisis led to further reforms in all of these areas. Following the demand for a precautionary credit line, the IMF Board responded with the creation of the short-term liquidity facility (SLF) in October 2008. It provided rapid access to loans for countries with "sound macroeconomic policies: and could be disbursed without the traditional IMF ex-post 
conditionality. Loans had a three-month maturity and were renewable twice during a twelvemonth period; borrowing limits were up to 500 percent of a country's quota. Yet, as the global crisis deepened and spread through the developing world, no country called upon the SLF. Because of the preconditions imposed, eligibility was more restricted than was hoped by the group of developing countries, represented in particular in the G-24.

There was active debate at the time on why this facility had not been used. It is probable that the handful of countries that were eligible for the SLF were those who were least in need of loans from the IMF, as they could raise capital through private or bilateral sources. In fact, the same day that the IMF announced the creation of the SLF, the U.S. Federal Reserve finalized reciprocal currency arrangements with Mexico, South Korea, Singapore, and Brazil -four countries which would have most likely qualified for IMF loans under the SLF. These swap lines were initially given for one year and limits of up to US\$30 billion, with maturities ranging from overnight to three months. For these countries, Fed swap lines (and others that arouse later on around the world) were clearly superior to IMF loans, both in terms of flexibility and lack of conditionality. An interesting case is that of Mexico, which publicly stated that it had no plans of ever using the SLF (though welcomed its establishment) but activated the Fed lines in order to help private firms who were facing a scarcity of dollar liquidity after the Lehman collapse. This implies that Mexican officials viewed the SLF as certainly inferior to the Fed swap line.

The then UNDP Administrator, Kemal Dervis (2008) expressed at the time concern that programs such as the SLF and the Fed's swap facilities effectively create two groups of countries -those deemed by the IMF and wealthy countries as having solid macroeconomic foundations and those which do not. In calling for expanding access to the SLF, he stated that such an "all or nothing categorization will create serious political tensions... [and] will also make it politically difficult for these governments [who are left out] to engage in such negotiations if other countries have immediate access to assistance from the IMF or Central Bank swaps”.

Others have emphasized that the three-month term limit on loans from the SLF were too short. Furthermore, and most problematic, while the IMF stressed that the countries borrowing from the SLF had sound macroeconomic policies in place, many countries avoided the SLF because of the stigma that traditionally accompanies IMF loans. Countries would not want to risk further capital flight by signaling instability and uncertainty with an IMF loan.

As a result of strong pressure to take more daring measures, in March 2009 the IMF approved an overhaul to the Fund's lending framework (IMF, 2009d). The reform's design has several novel elements. First, it eliminated the ties between structural conditionality and loan disbursements, and so the need for countries that did not implement structural reforms attached to programs to ask for waivers. Second, it doubled all credit lines, increasing annual and cumulative access limits for Fund resources to represent 200 and 600 percent of quotas, respectively. Third, it created the Flexible Credit Line (FCL) which was intended to fill the gap left by the cancelation of the CCL and lack of use of SLF. Like its predecessors, this facility was aimed at countries with strong macroeconomic fundamentals, had only the form of pre-qualification and, therefore, no explicit conditionality, but it now had no cap, although it is not expected to exceed ten times the quota. Finally, for countries that did not qualify for the FCL, the IMF Stand-by Arrangements (SBA) were made more flexible so as to allow their use as a crisis prevention instrument, through what came to be called "high-access 
precautionary arrangements" (HAPAs). As in the case of the FCL, resources can be frontloaded or treated as a strict precautionary instrument. These reforms were accompanied by the elimination of several existing credit lines (SRF, CFF and SLF).

Somewhat later, in July 2009, the IMF made new announcements on its concessional lending facility for low-income countries (IMF, 2009e). In addition to previous doubling the credit limits (which some countries consider as low levels as percentage of quotas), it increased overall lending capacity to US\$17 billion through 2014. The unified facilities under the Poverty Reduction and Growth Trust (PRGT) now include three different options: an Extended Credit Facility (the successor of the PRGF) for multi-year support for countries with balance of payments difficulties; a Stand-By Credit Facility to address short-term and precautionary needs on concessional terms; and a Rapid Credit Facility for emergency support (such as a natural disaster or a temporary external shock) with limited conditionality. In addition, the IMF approved zero interest payments up to the end of 2011 for all concessional loans and lower interest rates thereafter.

The IMF also reformed the framework for concessional lending for low-income countries starting in December 1, 2009 (IMF, 2009f). The new framework moved away from the single design of concessionality requirements towards a menu of options. This menu approach is intended to take better account of the different situations faced by these countries with regard to their debt vulnerabilities and their macroeconomic and public financial management capacity ("capacity"). Under this framework, each of the two above-mentioned factors can take two values: "lower" or "higher". Thus, this framework results in four different types of concessionality requirements. Unless debt sustainability is a serious concern ("higher" value) and capacity is limited ("lower" value), the applicable concessionality requirements normally allow for non-concessional borrowing. Moreover, a country where debt vulnerabilities are relatively high would be required to adopt tighter concessionality requirements. 
Table 10: IMF Lending by Countries, 2008-2009 (Million SDRs)

\begin{tabular}{|c|c|c|c|c|}
\hline Country & $\begin{array}{l}\text { Arangement } \\
\text { Type }\end{array}$ & $\begin{array}{l}\text { Approval } \\
\text { Date }\end{array}$ & $\begin{array}{l}\text { Total Scheduled Amount } \\
\text { (SDRs MM) }\end{array}$ & $\begin{array}{l}\text { Total withdrawn, } \\
\text { March 5, } 2010 \\
\text { (SDRs MM) }\end{array}$ \\
\hline \multicolumn{5}{|c|}{ Low Income Countries PGR-EFF } \\
\hline Liberia & PRGF-EFF & $3 / 14 / 2008$ & 582 & 568 \\
\hline Togo & PRGF & $4 / 21 / 2008$ & 66 & 58 \\
\hline Mali & PRGF & $5 / 28 / 2008$ & 28 & 20 \\
\hline Niger & PRGF & $5 / 28 / 2008$ & 23 & 7 \\
\hline Zambia & PRGF & $6 / 4 / 2008$ & 49 & 165 \\
\hline Burundi & PRGF & $7 / 7 / 2008$ & 46 & 20 \\
\hline Djibouti & PRGF & $9 / 17 / 2008$ & 13 & 5 \\
\hline Malawi & ESF & $12 / 3 / 2008$ & 52 & 35 \\
\hline Congo, Republic of & PRGF & $12 / 8 / 2008$ & 8 & 4 \\
\hline Sao Tome And Principe & PRGF & $3 / 2 / 2009$ & 3 & 0 \\
\hline Cote D'ivoire & PRGF & $3 / 27 / 2009$ & 374 & 195 \\
\hline Tajikistan & PRGF & $4 / 21 / 2009$ & 78 & 26 \\
\hline Ghana & PRGF & $7 / 15 / 2009$ & 387 & 68 \\
\hline Ethiopia & ESF & $8 / 26 / 2009$ & 154 & 74 \\
\hline Comoros & PRGF & 9/21/2009 & 14 & 4 \\
\hline Congo, Democratic Rep. & PRGF & $12 / 11 / 2009$ & 346 & 49 \\
\hline Seychelles & EFF & 12/18/2009 & 37 & 12 \\
\hline Total & & & 2,261 & 1,310 \\
\hline \multicolumn{5}{|c|}{ Other Countries - Stand by Agreements } \\
\hline Honduras & SBA & $4 / 7 / 2008$ & 39 & 0 \\
\hline Georgia & SBA & 9/15/2008 & 477 & 430 \\
\hline Ukraine & SBA & $11 / 5 / 2008$ & 11,000 & 7,000 \\
\hline Iceland & SBA & $11 / 19 / 2008$ & 1,400 & 560 \\
\hline Pakistan & SBA & $11 / 24 / 2008$ & 5,169 & 4,169 \\
\hline Latvia & SBA & $12 / 23 / 2008$ & 1,521 & 714 \\
\hline Belarus & SBA & $1 / 12 / 2009$ & 1,618 & 1,832 \\
\hline El Salvador & SBA & $1 / 16 / 2009$ & 514 & 0 \\
\hline Serbia & SBA & $1 / 16 / 2009$ & 351 & 1,021 \\
\hline Armenia & SBA & $3 / 6 / 2009$ & 377 & 303 \\
\hline Mongolia & SBA & $4 / 1 / 2009$ & 153 & 107 \\
\hline Costa Rica & SBA & $4 / 10 / 2009$ & 492 & 0 \\
\hline Guatemala & SBA & $4 / 22 / 2009$ & 631 & 0 \\
\hline Romania & SBA & $5 / 4 / 2009$ & 11,443 & 6,088 \\
\hline Bosnia \& Herzegovina & SBA & $7 / 8 / 2009$ & 1,015 & 183 \\
\hline Sri Lanka & SBA & $7 / 24 / 2009$ & 1,654 & 207 \\
\hline Dominican Republic & SBA & $11 / 9 / 2009$ & 1,095 & 200 \\
\hline Angola & SBA & $11 / 23 / 2009$ & 859 & 229 \\
\hline Maldives & SBA & $12 / 4 / 2009$ & 57 & 5 \\
\hline Total & & & 39,864 & 23,048 \\
\hline \multicolumn{5}{|l|}{ Flexible Credit Line } \\
\hline Mexico & FCL & $4 / 17 / 2009$ & 31,528 & \\
\hline Polonia & $\mathrm{FCL}$ & $5 / 6 / 2009$ & 13,690 & \\
\hline Colombia & FCL & $5 / 11 / 2009$ & 6,966 & \\
\hline Total & & & 52,184 & \\
\hline
\end{tabular}

Shortly after its creation the Flexible Credit Line, three countries requested and were granted access to it. Interestingly, on the eve of the April 2, 2009, G-20 meeting in London, Mexico became the first country to use the new facility. As we pointed out above, it had explicitly refused to use the SLF, and now requested almost three times the amount borrowed during its 1994 crisis. Poland and Colombia soon joined, increasing the demand for the FCL to SDR52.2 billion (approximately US $\$ 80$ billion at current exchange rates), in fact more than all other programs together (see Table 10). However, there have been no demands since then on this facility, nor drawings by any of the three countries. This may reflect improvements in global financial conditions, but may also indicate that the three countries that used it were essentially asked to do so to show that this credit line would not fail as its predecessors. So, after all, it may not have been a success. The new credit line also continues to be plagued by the problems underscored by Dervis in relation to the SLF. 
Before the Lehman collapse, demands for IMF resources were very low, and came mainly from low-income countries. Only one country, Honduras, had been approved a Stand-By Agreement in 2008 before the Lehman collapse, but after that there were growing demands on the IMF (see again Table 10). The first countries to come for support through a Stand-By Agreement were Georgia, Iceland, Latvia, Pakistan and Ukraine. They all signed a Stand-by Arrangement. Among others to step in early 2009 were Armenia, Belarus, Mongolia and Romania, who received front-loaded programs, and Costa Rica, El Salvador, Guatemala and Serbia that received precautionary programs. During the second semester of 2009, Angola, Bosnia-Herzegovina, the Dominican Republic and Maldives were added to the list. The two largest programs, those for Romania and Ukraine exceeding SDR10 billion are among the largest loans in IMF history, and together constitute more than half of the total financing approved through the SBA facility. In turn, the 17 PRGF-EEF programs approved to lowincome countries during 2008-2009 represent much smaller amounts (slightly under SDR2.3 billion) and a third was approved before the Lehman collapse.

Using IMF's Monitoring of Fund Arrangements (MONA) database, which contains information on conditionality in the Fund-supported arrangements and tracks the performance of countries, Figure 8 shows IMF's structural conditionality in the current crisis per program. For the SBA program, the average number of structural conditions per country in the period 2008-2009 was 12, while on average most of the conditions were Structural Benchmark (SB), 7, followed by Prior Action (PA), 3, and Performance Criterion (PC), 1. For the PRGF program, the average number of structural conditions per country in the period 2008-2009 was 15, while on average most of the conditions were Structural Benchmarks (SB), 9, followed by Performance Criteria (PC), 3, and Prior Action (PA), 2. For all IMF programs in 2008-2009, the average number of structural conditions totaled 13, compared to 17 found in the IMF-IEO report for the period 1995-2004, which could amount to an important reduction. For the PRGF arrangements, the average number of conditions remains constant at 15, while in SBA the number of conditions declined significantly from 19 to 12 . 
Figure 8: Number of Structural Conditions in IMF programs, 2008-2009.
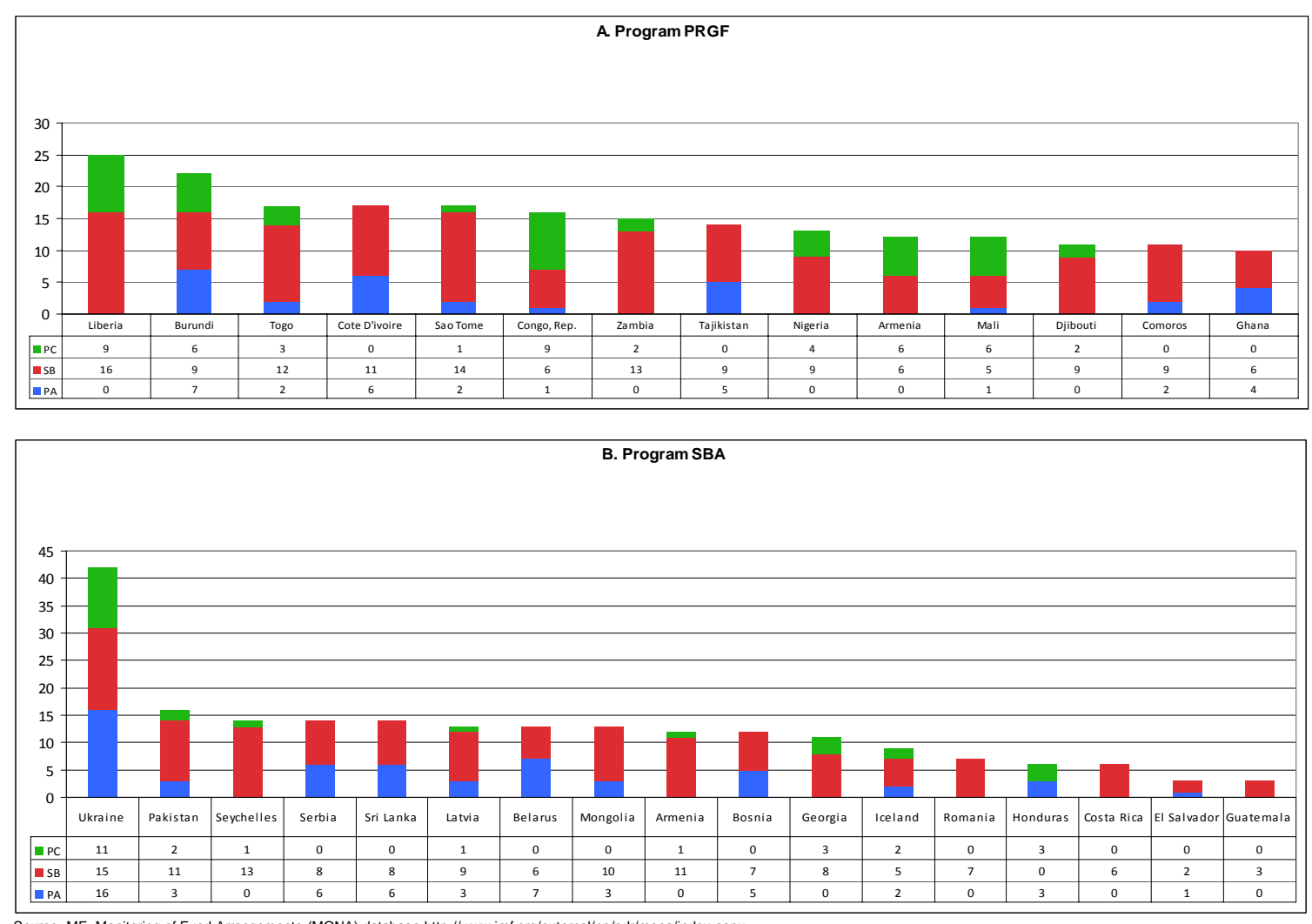

Source: MF, Monitoring of Fund Arrangements (MONA) database.http://wmw.imf.org/external/np/pdr/mona/index.aspx

As per the content of the structural conditions, the same data base indicates that, although most conditions were in the Fund's core mandate -public financial management and financial sector soundness-, it continued to push conditions in areas beyond it, though less if compared to the period before 2007. These non-core areas include state-owned enterprise reform, social policies, civil service reform or regulatory reform; this is particularly so for the subscribers of PRGF agreements (see Table A.1 and A.2 in the Appendix for some examples of structural conditions for the different countries that have sought IMF help from 2008 to 2009). ${ }^{18}$ There also remains significant criticism about the character of some of the macroeconomic policies which many analysts continue to perceive as pro-cyclical. ${ }^{19}$ However, the record here has probably improved too, as we have noted before in relation to some programs. In some cases, it may be correct to say that adjustment policies may be required to correct overly expansionary policies during the boom years or may be imposed by policy decisions adopted by countries themselves (e.g., decisions to maintain the currency board in the case of Latvia).

\section{2.- DEVELOPMENT FINANCING}

One of the most positive trends in the years before the crisis had been the positive trends in Official Development Assistance, a step not only in accord with old commitments by industrialized countries since the 1960s but also critical to meet the MDGs agreed in the UN

\footnotetext{
${ }^{18}$ To properly assess the significance of reductions in numbers, a deeper analysis of the content of the conditionality of specific programs would be required, but this is beyond the scope of this essay.

${ }^{19}$ An important contribution to this debate is the report by the Center for Economic Policy Research (CEPR) in October 2009 (Weisbrot et al., 2009), which indicates that in 31 out of 41 countries with IMF agreements have been subject to pro-cyclical fiscal and/or monetary policies, and the IMF has relied on overly optimist growth forecasts. The latter issue has been emphasized in several evaluations of the IMF throughout the years.
} 
Millennium Summit. The UN Conference on Financing for Development held in Monterrey, Mexico, in 2002 seems to have been the crucial turning point. ODA by members of the Development Assistance Committee (DAC) of OECD, which had declined in the 1990s from around $0.33 \%$ to $0.22 \%$ of GNI and stagnated since 1997 at that level, started to increase in a more or less systematic way, if we exclude debt relief. The 2005 commitments made in the Gleneagles G-8 and in the UN Millennium + 5 Summits further reinforced this trend. By 2008, ODA had increased to $0.30 \%$ of the GNI of DAC members. Efforts have also been made to improve the quality of aid in the context of the 2005 Paris Declaration on Aid Effectiveness and the 2008 Accra Declaration.

The trend was also important in terms of the structure of the assistance provided. Whereas the initial increase up to 2005 concentrated on debt relief, which is strictly speaking no new aid and largely benefited two countries (Iraq and Nigeria), later increases represented new funds. Furthermore, technical cooperation, which is largely spent on personnel from donor countries, has also remained stagnant. Excluding these two components, bilateral aid tripled in dollar terms in 2003-2008, as contributions to multilateral institutions increased by almost $80 \%$. In addition, aid to Africa has also increased sharply. Nonetheless, significant problems remain, including the fact that ODA has continued to fall short, not only of the commitment made since the $1960 \mathrm{~s}$ in the UN (0.7\% of the GNI of industrial countries), but even of the Gleneagles commitments made just five years ago. This is particularly true of aid to Africa, which in 2008 was about US\$ 20 billion below those more recent commitments. Aid has tended to concentrate in a few countries (Iraq and Afghanistan being among the largest recipients, who together concentrate about one-sixth of total aid) and has shown significant volatility at a country level. ${ }^{20}$

\footnotetext{
${ }^{20}$ See on these and other issues, UN (2009b).
} 
Table 11: Official Development Assistance

\begin{tabular}{|c|c|c|c|c|c|c|}
\hline & \multicolumn{3}{|c|}{$\begin{array}{c}\text { Total ODA } \\
\text { (millions of dollars) } \\
\end{array}$} & \multicolumn{3}{|c|}{$\begin{array}{c}\text { ODA } \\
\text { (\% of GNI) }\end{array}$} \\
\hline & \multicolumn{3}{|c|}{ Current Projection } & \multicolumn{3}{|c|}{ Current Projection } \\
\hline & 2008 & 2010 & 2010 vs 2008 & 2008 & 2010 & 2010 vs 2008 \\
\hline Total DAC countries & 119,759 & 107,401 & $-12,359$ & 0.30 & 0.33 & 0.03 \\
\hline Total EU & 70,168 & 62,009 & $-8,159$ & 0.42 & 0.48 & 0.06 \\
\hline Austria & 1,681 & 1,178 & -503 & 0.42 & 0.37 & -0.05 \\
\hline Belgium & 2,381 & 2,620 & 239 & 0.47 & 0.70 & 0.23 \\
\hline Denmark & 2,800 & 2,299 & -501 & 0.82 & 0.83 & 0.01 \\
\hline Finland & 1,139 & 1,112 & -27 & 0.43 & 0.55 & 0.12 \\
\hline France $^{\mathbf{a}}$ & 10,957 & 9,955 & $-1,002$ & 0.39 & 0.46 & 0.07 \\
\hline Germany & 13,910 & 11,300 & $-2,610$ & 0.38 & 0.40 & 0.02 \\
\hline Greece & 693 & 525 & -168 & 0.20 & 0.21 & 0.01 \\
\hline Ireland & 1,325 & 842 & -482 & 0.58 & 0.52 & -0.06 \\
\hline Italy & 4,444 & 3,426 & $-1,018$ & 0.20 & 0.20 & 0.00 \\
\hline Luxembourg & 409 & 313 & -96 & 0.92 & 1.00 & 0.08 \\
\hline Netherlands & 6,993 & 5,323 & $-1,670$ & 0.80 & 0.80 & 0.00 \\
\hline Portugal & 614 & 576 & -38 & 0.27 & 0.34 & 0.07 \\
\hline Spain & 6,686 & 5,652 & $-1,034$ & 0.43 & 0.51 & 0.08 \\
\hline Sweden & 4,730 & 3,915 & -815 & 0.98 & 1.03 & 0.05 \\
\hline United Kingdom & 11,409 & 12,975 & 1,566 & 0.43 & 0.56 & 0.13 \\
\hline Australia & 3,166 & 2,460 & -706 & 0.34 & 0.35 & 0.01 \\
\hline Canada & 4,725 & 3,542 & $-1,183$ & 0.32 & 0.33 & 0.01 \\
\hline Japan & 9,362 & 9,546 & 184 & 0.18 & 0.20 & 0.02 \\
\hline New Zealand & 346 & 324 & -23 & 0.30 & 0.34 & 0.04 \\
\hline Norway & 3,967 & 2,995 & -972 & 0.88 & 1.00 & 0.12 \\
\hline Switzerland & 2,016 & 1,820 & -196 & 0.41 & 0.47 & 0.06 \\
\hline United States & 26,008 & 24,705 & $-1,304$ & 0.18 & 0.20 & 0.02 \\
\hline
\end{tabular}

In this light, the recent trends are not entirely encouraging, as Table 11 indicates. This Table compares 2008 ODA levels with projections for 2010, according to the OECD Development Assistance Committee. As it can be seen, ODA levels in dollar terms are expected to reach in 2010 a level some $10 \%$ below that of 2008. This reduction is mainly the result of the reduction of the GNI of donor countries, particularly expressed in US dollar due to exchange rate movements, as in fact ODA will reach in 2010 a level equivalent to $0.33 \%$ of GNI, slightly above 2008 levels. This is furthermore true of most countries, with some showing significant increases in the proportion of the GNI destined to ODA. There are, in fact, only two exceptions to this trend, Austria and Ireland, and only one additional country which will show a lower level of aid than in 2008, Italy (Netherlands also, but it is one of the countries that exceeds the UN target). Thus, despite positive regular announcements, trends have not been quite so positive in this area.

In relation to the MDBs, the crisis demonstrated the crucial counter-cyclical role that they can play when private financial markets dry up and when other shocks occur. Whilst the international community had emphasized the role that MDBs play in poverty reduction and the provision of global public goods, this counter-cyclical role had not been explicitly recognized. The lack of recognition of this role missed many lessons from past experience, which indicated that, aside from provision of liquidity during crises, it is equally important to provide official long-term finance when private finance dries up during and after crises, particularly to maintain the dynamics of public sector investment projects. 


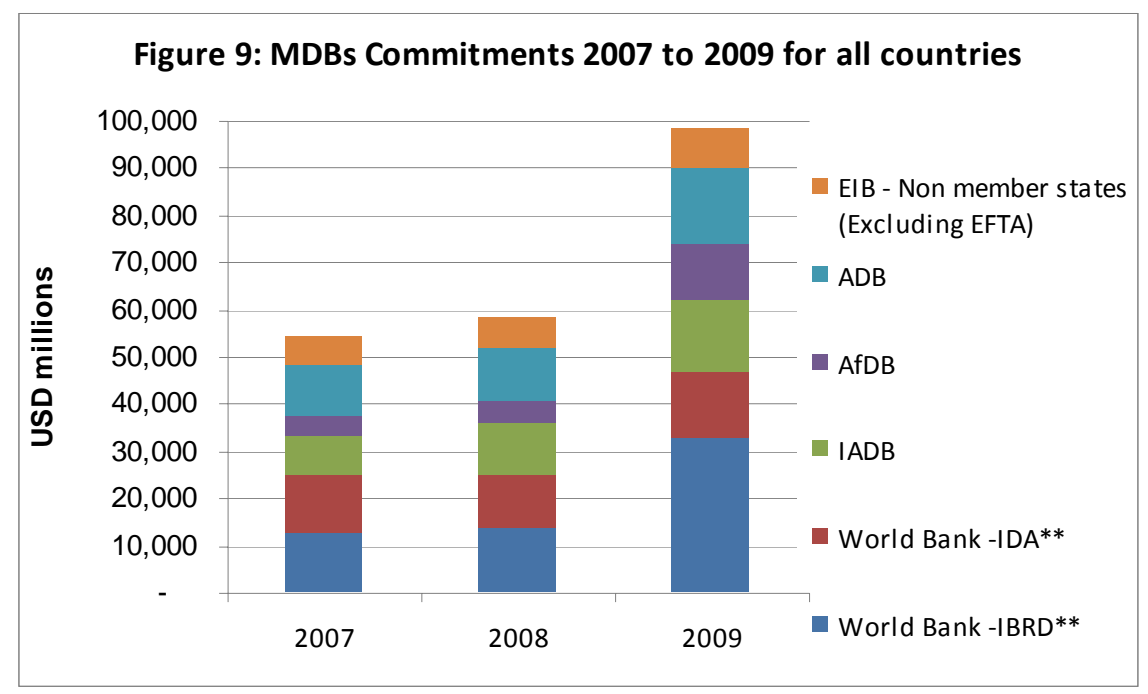

As Figure 9 and Table 12 indicate, as a group the MDBs increased significantly their lending commitments to developing and emerging economies, by 69\% in 2009, compared with 2008. Their disbursements also grew by $46 \%$ in the same year. This was an important countercyclical response, which moderated (though could not fully compensate for) the impact of the sharp decline of private flows to developing countries. This therefore helped to soften the effect of the crisis on developing countries, and helped sustain growth in developing countries.

Table 12: MDBs Commitments and Disbursements, 2007-2009

\begin{tabular}{|c|c|c|c|c|}
\hline ALL COUNTRIES (USD Millions) & 2007 & 2008 & \multicolumn{2}{|c|}{2009 Change 08-09 } \\
\hline \multicolumn{5}{|l|}{ COMMITMENTS } \\
\hline World Bank -IBRD** & 12,829 & 13,468 & 32,911 & $144 \%$ \\
\hline World Bank -IDA** & 11,867 & 11,235 & 13,995 & $25 \%$ \\
\hline IADB & 8,577 & 11,085 & 15,278 & $38 \%$ \\
\hline AfDB & 4,004 & 4,928 & 11,692 & $137 \%$ \\
\hline ADB & 10,770 & 11,329 & 16,078 & $42 \%$ \\
\hline EIB - Non member states (Excluding EFTA) & 6,390 & 6,145 & 8,597 & $40 \%$ \\
\hline TOTAL & 54,436 & 58,189 & 98,550 & $69 \%$ \\
\hline \multicolumn{5}{|l|}{ DISBURSEMENTS } \\
\hline World Bank -IBRD** & 11,055 & 10,490 & 18,564 & $77 \%$ \\
\hline World Bank -IDA** & 8,579 & 9,160 & 9,219 & $1 \%$ \\
\hline IADB & 6,725 & 7,149 & 11,424 & $60 \%$ \\
\hline AfDB & 2,464 & 2,926 & 6,575 & $125 \%$ \\
\hline ADB & 7,858 & 9,724 & 12,946 & $33 \%$ \\
\hline EIB - Non member states (Excluding EFTA) & 4,571 & 4,429 & 5,121 & $16 \%$ \\
\hline TOTAL & 41,252 & 43,878 & 63,848 & $46 \%$ \\
\hline
\end{tabular}

The response of the MDB system was partly constrained by the limitation of their capital (te Velde and Massa, 2009). In April 2009, the G-20 agreed to support, if necessary, the recapitalization of MDBs to enable increased lending. The Asian Development Bank (ADB) agreed, in April 2009, to a capital stock increase of 200\% to US\$165 billion from US\$55 billion. The capital of the African Development Bank (AfDB) was also increased by $200 \%$ in the 2009 spring meetings and, despite the fact that expectations were not entirely fulfilled, 
that of the Inter-American Development Bank (IADB) was increased by US\$70 billion in its March 2010 annual meetings.

An interesting feature of the MDB response was is that a number of targeted large regional initiatives were launched, mainly working jointly with other institutions, notably the World Bank working together with regional development banks (RDBs). Examples are the Joint Plans in Africa, Latin America and the Caribbean, and for Central and Eastern Europe (te Velde and Massa, 2009, for more details). In normal times, the World Bank and the RDBs often compete amongst each other. The massive needs caused by the crisis pushed these institutions to collaborate rather than compete. It would be valuable if this modus operandi could also be maintained for normal times, especially for large projects, such as regional infrastructure.

The World Bank responded strongly to the crisis by almost doubling lending commitments, from US\$25 billion in fiscal year 2008 (ending in June) to US\$45 billion in 2009. Two of the areas of increased attention were human development and social protection, though financial and private sector development continued to represent a large share of new commitments. Though the World Bank's statements stressed also infrastructure and support for SMEs as priority areas, it is less clear that this occurred on a sufficient scale.

A major issue was the insufficient response by the World Bank to the needs of low-income countries. This has been widely criticized, including by the UK Development Minister, Douglas Alexander, who pointed out that disbursements to Africa had actually fallen. Indeed, whereas IBRD lending to middle-income countries substantially increased from 2008 to 2009, by US $\$ 19.4$ billion or $144 \%$, IDA lending to low-income countries was only increased by US $\$ 2.8$ billion or $25 \%$ (Table 12). The proposal, presented at the end of 2009 , to create an US\$ 1.3 billion IDA Crisis Response Facility, to disburse IDA funds for protecting core spending on health, education, safety nets, infrastructure is thus very welcome. However, it is disappointing that the facility will start only as a smaller pilot, and resources will not be additional, but come from existing IDA monies.

The problem of limited attention to low-income countries was also present in other MDBs. Indeed, if we look at MDBs as a group (see Table13), the share of lending commitments to low-income countries , as proportion of the total, fell from 32\% in 2007 to $28 \%$ in 2008 and declined further to 22\% in 2009. In the case of the European investment Bank (EIB), such lending actually fell. The relative neglect in the response of MDBs is, therefore, a dark spot on an otherwise impressive countercyclical performance. In this aspect, low-income countries were thus the Cinderellas of the international response. 
Table 13: MDBs Commitments for low-income countries, 2007-2009

\begin{tabular}{|lrrr|r|}
\hline & 2007 & 2008 & 2009 & Change 08-09 \\
\hline COMMITMENTS & & & \\
World Bank -IBRD** & - & - & \\
World Bank -IDA** & 11,867 & 11,235 & 13,995 & $25 \%$ \\
IADB & 220 & 245 & 278 & $13 \%$ \\
AfDB & 1,577 & 2,401 & 2,781 & $16 \%$ \\
ADB & 3,166 & 1,765 & 4,066 & $130 \%$ \\
EIB - Non member states & 701 & 406 & 539 & $33 \%$ \\
TOTAL & $\mathbf{1 7 , 5 3 1}$ & $\mathbf{1 6 , 0 5 2}$ & $\mathbf{2 1 , 6 5 9}$ & $\mathbf{3 5 \%}$ \\
As \% of "all country" commitments & $\mathbf{3 2 \%}$ & $\mathbf{2 8 \%}$ & $\mathbf{2 2 \%}$ & \\
\hline
\end{tabular}

Source: Annual Reports and Internal Data

The dynamics of commitments were not reflected, however, in disbursements. In the case of the World Bank, the increase in IBRD disbursements was impressive (77\%), though much slower than commitments, whereas the growth of IDA disbursements was insignificant (1\%). The slower pace of disbursement relative to commitments is even true of policy lending, which should be quicker to disburse, and took place despite a number of measures that were reportedly taken to accelerate disbursements, such as frontloading and fast tracking loans. The story would be worse if we focused on net disbursements (i.e., net of payments by countries to the MDBs). This means in practice that the contribution of the World Bank to the recovery was moderate at best, and certainly so in the case of low-income countries. This needs urgent review and change both for future crises, so as to fully mainstream the counter-cyclical function.

Some of the RDBs also responded with strong increased in lending during the crisis. The Inter-American Development Bank (IADB) did so with many policies running parallel to World Bank initiatives, including loosening policy criteria and creating a rapid disbursing emergency fund of US\$6 billion to allow faster disbursements of funds, and increasing callable capital by US\$4 billion. IADB increased its commitments by $38 \%$ in 2009, having also increased disbursements significantly in 2008, and disbursed 60\% percent more in 2009 than in 2008.

The European Bank for Reconstruction and Development (EBRD) increased lending in 2009 by over $50 \%$ to $€ 7.0$ billion, with about a fourth directed to supporting the financial sector and medium and small-sized enterprises and transport as additional priorities. ${ }^{21}$

The European Investment Bank (EIB) also followed the pattern of other multilateral development banks in increasing substantially lending in response to the crisis, both to EU members, its main beneficiaries, but also developing countries. Lending to developing and emerging countries in 2009 increased by $40 \%$, though disbursements by a mere $16 \%$. This slow increase in disbursements may be partly explained by the fact that the EIB lends only for projects, which are not disbursed as quickly as sectoral or program lending. It is interesting that in certain regions, such as Asia and Latin America, there was high demand for EIB lending, but the limits imposed by the existing predetermined envelope of lending to those regions was a constraint.

\footnotetext{
${ }^{21}$ Quoted from Varel Freeman, EBRD First Vice President. See http://www.ebrd.com/new/stories/2009/090512.htm.
} 
The African Development Bank also developed a number of changes in programs and policy to respond to the crisis. Its lending commitment increased by an impressive $137 \%$ between 2008 and 2008, with disbursements growing by an also impressive 125\%. This was the largest increase of disbursements in 2009 of any MDBs. However, again the scale and targeting to the most vulnerable countries remained somewhat inadequate.

For the Asian Development Bank, commitments in 2009 grew by $42 \%$ and disbursements by 33\% (see again Table 12).

The main lesson learned is that MDBs need to permanently place their counter-cyclical function at the center of their priorities and develop the instruments to do so, allowing them to respond rapidly and significantly in times of crises. MDB disbursements grew far slower during the crisis than did commitments, leading to the need to create ex ante mechanisms for fast disbursements during crises. Critical in this area is social protection where speed in delivery is the essence in effectiveness. An important question is whether lower conditionality in lending could have helped. There are sub-regional banks -CAF, Corporación Andina de Fomento-which lend much quicker than most MDBs and that have less conditionality. A recent example of such fast disbursement is increased lending through intermediaries (global loans) for SMEs by the EIB.

Given that lending was initially constrained by insufficient capital in several MDBs, a crucial policy question is whether greater automaticity in replenishing the capital of these valuable institutions should be introduced. Replenishing the capital is additionally important given the additional tasks given to MDBs of helping meet global public goods urgently, such as mitigating and adapting to climate change. If capital is not replenished, then the residual capacity to lend to development will fall, as will their ability to lend counter-cyclically in crises. To accelerate the response to low-income countries, a significant increase in IDA resources is required, as well as grants to finance concessional loans in RDBs.

An alternative avenue to replenishment is increasing the capacity of MDBs to lend in future is via higher leverage. This is especially attractive to developed country governments facing severe budget and debt constraints. There are a number of ways in which an MDB can create more leverage of its capital. Firstly and most traditionally is the use of guarantees as opposed to loans. In addition, less traditional methods of leverage and signaling can be adopted including the provision of equity or mezzanine financing. It is interesting that IDA has recently recommended that its pilot partial risk guarantee mechanism be mainstreamed and become a regular product.

MDBs can also be more active in providing concessional lending, most notably obtained by blending loans and grants, particularly but not only for low-income countries. Sufficient levels and good allocation of grant subsidies is an important factor in enabling this, and should be a top priority for policymakers.

One area where the MDBs, including the World Bank Group, were rather effective in meeting clear needs originating from the crisis was in terms of rapid provision of trade credit facilities. The expansion of trade credit by MDBs overall provided US\$9.1 billion in addition to the US\$3.2 billion that they had been providing. The short maturity of most trade financing allows funds to be rolled over multiple times, providing more than US\$80 billion in trade financing between 2009 and 2011. A majority of banks surveyed by the International 
Chamber of Commerce (55\%) were utilizing trade facilitation programs implemented by MDBs by the summer of 2009 (ICC, 2009).

Another set of policy proposals for the future relate to the MDBs introducing lending instruments that make developing countries less vulnerable during crises, either because they reduce currency mismatches by lending in local currency or because they adjust repayments of loans in a counter-cyclical manner, so that net lending can increase more in bad times.

An instrument which several MDBs have developed successfully in certain countries is lending in local currencies. It seems highly desirable that MDBs extend local currency lending to other countries given that local currency debt implies no currency mismatches for the debtor and therefore reduces the risk of debt crises, as well as risk of bankruptcies of individual companies. Where feasible, this should be funded by issuing debt of the MDB in the same currency. This both eliminates foreign exchange risk for the MDB and helps the development of local capital markets. The MDBs could take a step further and create a diversified portfolio of local currency debt of a variety of developing countries. Such a diversified portfolio could be securitized and sold (see proposals by Dodd and Spiegel, 2005 and Ocampo and Griffith-Jones, 2008).

However, there are cases (for example global loans to SMEs) where a MDB can make a loan in foreign currency to the intermediary bank. This bank, because it has a surplus of deposits in local currency in one country or subsidiaries in many different countries (which gives it the benefits of diversification), may be willing to onlend to SMEs in their local currency, even though the funding it received was in foreign exchange. The key is that the MDB should ensure that the lending with its resources to companies whose sales are in local currency, is also done in the same local currency.

The MDBs could also take one step further and innovate by pioneering other new instruments as they did previously with local currency paper. There seems to be a strong case for GDPlinked bonds for developing countries. Such instruments would help stabilize government spending through the cycle, helping to smooth growth and diminish the likelihood of costly debt crises. There seems to be a typical "first mover" problem. Individual governments, though seeing the insurance advantages which have become far more evident in the recent crisis, seem shy about being the first to issue GDP-linked bonds. Therefore, they express a strong preference for MDBs to act as "market-makers". The MDBs could do this by making loans linked to the growth of GDP; such loans could then be grouped, securitized and sold to financial markets.

Another area where the crisis can offer valuable lessons for future actions is the need for closer collaboration of different MDBs such as to build regional infrastructure; the crisis seems to have encouraged different MDBs to work more closely. The institutional mechanisms created for this task should be maintained also in normal times. 



\section{5.- conclusions and global policy implications}

The Great Recession had strong though quite diverse effects on the developing and transition economies. One channel of transmission was through falling remittances, which impacted several, mostly small countries heavily dependent on remittances of migrants to the US, Western Europe and Russia; in contrast, remittances from the Gulf countries to South Asia and the Middle East did not experience a similar downward trend. The financial shock was severe, mainly for middle-income "emerging" economies, but it was short, thanks to the largest Keynesian policies ever adopted in history, including those put in place by several major developing countries, and to the massive bailouts of financial institutions in industrial countries. The trade shock was also severe, longer lasting (its effects are still visible today) and affected all countries. In the developing world, high and mid-tech manufacturing exporters were hardest hit by the collapse of export volumes. In turn, energy and metal exporters were initially more affected by the collapse of commodity prices than agricultural producers. Dependence of many low-income countries on agricultural exports thus turned out to be a relative blessing under the circumstances. In a longer term perspective, however, real agricultural prices came back to levels below those of the 1970s, in sharp contrast to relatively high real oil and metal prices that prevailed again at the end of 2009.

Countries and regions hardest hit in terms of GDP contraction are clustered in two groups. The first is made up of those countries with weak external balance sheets (large external debts relative to foreign exchange reserves) and/or traditional domestic financial vulnerabilities (a previous boom of foreign private sector borrowing followed by a credit squeeze and, even worse, the devastating effects of currency mismatches in domestic portfolios). This is the situation faced by many transition economies of Central and Eastern Europe as well as several that are now members of the European Union (with Poland as a major exception). The second group comprises manufacturing exporters heavily dependent on US and European markets. The high-income and highly open East Asian economies of South Korea, Taiwan, Hong Kong, Singapore, along with Mexico and Turkey are the main cases in point. China's exports were also strongly affected but this country came out from the slowdown generated by the Great Recession very soon, thanks to the most expansionary fiscal and credit package in the world. Indeed, in a significant way, aside from the massive Keynesian policies and bailouts, the other major difference between the Great Recession and the Great Depression of the 1930s was that this time the world had, in China, a substantial economy with strong trade linkages and without a financial sector in crisis and, therefore, with the policy space and willingness to pursue aggressive Keynesian policies.

Aside from China, many other developing countries adopted variable mixes of expansionary fiscal, monetary and credit policies. Most East and South Asian countries (with the major exception of Pakistan), together with Brazil stand out in this regard; and in South Asia, this was true of fiscal policies despite their initial weak fiscal stances. But there are similar cases of expansionary policies, including in Sub-Saharan Africa. The existence of state financial institutions (as in Brazil, China and India) turned out to be a blessing for supporting expansionary policies, whereas the credit squeeze in countries with heavy dependence of banks on external funds defeated otherwise very expansionary macroeconomic policies (with Chile and several Gulf countries being major examples of this pattern). There were few 
domestic financial crises, thanks, basically, to stronger regulation in place, as a response to the developing countries’ own past crises.

Overall, China and South Asia (notably India but also the largest least developed country, Bangladesh) had the best performance, and North and Sub-Saharan Africa a fair one (though on average per capita income fell in Sub-Saharan Africa). The performance of South Asia and much of Sub-Saharan Africa, the two regions with the highest incidence of extreme poverty, implied that the effects of the Great Recession on world poverty have been relatively muted so far. Whilst the deviation from the success achieved during the 2003-2007 boom in advancing towards the Millennium Development Goals has thus far been not fatal, there are serious concerns about the continuing impact on world poverty of a slow and prolonged world recovery. Most other economies in East Asia, as well as Brazil, experienced a strong recovery after the initial recession. Overall, however, Latin America did not do well despite stronger external, financial and fiscal stances than in the past. This is particularly true of Mexico, which along with Turkey was amongst the economies that experienced strong contractions. The worst hit by the Great Recession were the transition economies, particularly the CIS countries but also some that are now EU members.

Multilateral response was strong (and certainly stronger than during past crises), as reflected in the largest emission of Special Drawing Rights (SRDs) in history, major innovations in IMF programs, some improvement in its conditionality, and rapid increase in lending by the Multilateral Development Banks. However, that response exhibited two major weaknesses. First, it was much weaker than the shock warranted, given the strong contraction in private financial flows, and came with a lag. In the case of the MDBs, large expansions in commitments were not matched by an equally dynamic pace of disbursements, so that its contribution to the recovery was moderate. Second, it was biased towards middle-income countries. This was reflected both in the responses from the IMF and the Multilateral Development Banks, as well as in reduction of Official Development Assistance.

Going forward, there are major uncertainties that surround the world economy and associated global policy issues. Those that have received greatest attention relate to the need to avert early withdrawal of stimulus in the industrial countries, and to face the implications of rising public sector debts, which have short-term effects on financial markets and medium- and longer-term implications on the policy space that these countries have to continue using fiscal expansion. We will leave these issues aside, as well as the important long-term questions pertaining to the relationship between future world economic growth and climate change. We will concentrate, rather, on five issues that we see as particularly important in terms of global economic policy and the developing world.

The first relates to the large asymmetries between the expected growth of industrial and developing countries. The world had never experienced before a situation in which, given the weakness of industrial countries, major developing countries are, in a sense, the only available engines of world economic growth. Continuing expansion of these countries is therefore crucial for the world, but so is the capacity of these economies to transmit their growth dynamics to the rest of the world. The most important is, of course, China, which has a much larger share of global trade than other large developing countries. In the case of China, the capacity to induce growth in the rest of the world inevitably implies turning its large trade surplus into a balance or even a trade deficit. This problem is absent in other large developing 
countries, like Brazil and India, which have the tendency to run current account deficits anyway.

In the case of China, the transition from export-led to domestic-led growth raises a myriad of questions, including the capacity to shift domestic demand dynamics from investment to consumption and, therefore, the reversal of the dramatic reduction of consumption and wage shares, as well as the significant overcapacity generated by the highest investment rate ever recorded in history (Akyüz, 2010; Yu, 2010). Also, given that large parts of its trade linkages are associated with the demand for inputs for its export sector, the shift from export-led to domestic demand-led growth may actually reduce Chinese import demand (Akyüz, 2010).

Under any scenario, it is essential that the world does not throw the baby out with the bathwater, to use a typical American saying. In particular, although some real appreciation of the renminbi should be part of this process, a strong and disorderly appreciation may have the effect of seriously affecting Chinese economic growth. This is a likely interpretation of how Japanese growth came to a halt and its costly financial crisis was incubated. In any case, it is the one that Chinese authorities seem to have in mind to avoid repeating the story. The only desirable scenario is, therefore, a Chinese economy that transmits its stimulus to the rest of the world through rising imports generated more by the income (rapid economic growth) than the substitution (real exchange rate appreciation) effects. Opening space for Chinese investment abroad should also be an essential part of this strategy.

A second and interrelated issue is the implication of current trends on global imbalances. One of the major paradoxes of the Great Recession is that building stronger external balance sheets in the developing world through self-insurance contributed first to building up global imbalances during the boom years, that dampened global demand, which then came to depend heavily on the US as "the consumer of last resort"; but second, the resulting strong external balance sheets also contributed to the resilience of many developing economies during the Great Recession, which has was a major factor behind the recent recovery. Going forward, the worst global scenario is thus one in which all or most countries, including now industrial nations, aim at improving their current accounts, as current IMF projections indicate, since this is nothing but a scenario of weak global demand and even a new recession. A desirable global scenario is thus one in which most developing countries (and not only China) run current account deficits. However, this requires major reforms in the global financial system to reduce the vulnerabilities that this pattern generated in the past and that were reflected in major financial crises in the developing world. Recent IMF reforms are just a small step in that direction, and must be followed by many additional reforms. It is essential, in particular, to create a sovereign debt resolution mechanism and active financing during crises, through a mix of counter-cyclical issuance of SDRs and emergency financing without onerous conditions (UN, 2009c).

Furthermore, generating these current account deficits the way they are now being pushed by financial markets, through massive capital flows towards emerging markets, runs the risk of generating future busts, following well-known patterns. So, a more orderly way of inducing such current account deficits without risking the disruption in world economic growth should be on the cards. In our view, this inevitably require a serious discussion of capital account regulations in the world, an issue that has been raised by several analysts (see, for example, Subramanian, 2009 and Ocampo, 2010), but is surprisingly missing from current discussions of global financial reform. 
A third set of questions relates to the weakest link in the current recovery: international trade. There are two scenarios here: a continuation of the rapid recovery of trade that started in mid2009 and that will generate a return to the situation that prevailed in recent decades, of a world trade that is more dynamic than world GDP; or, alternatively, a situation in which this will not happen, and we are going to see a world in which trade is not particularly dynamic, and not necessarily because protectionism is back on the agenda. We are inclined to think that the second outcome is quite likely and, furthermore, that even a successful Doha trade round (a very unlikely scenario) would not make much of a difference for the outcome. If this is so, the best world scenario is, curiously, the return of inward-looking strategies, not necessarily protectionist but with a focus on the dynamism of domestic markets. After all, the Keynesian policies that have been the essential ingredient of the current recovery are nothing else than inward-looking policies.

What this implies is that the desirable situation is more like that of the late nineteenth and early twentieth century according to some economic historians (notably Bairoch, 1993), in which economic growth of different nations (in, for that matter, generally protectionist world) was the engine of world trade, and not the opposite. In recent decades, the "trade as an engine of growth" view has, curiously though in different ways, been both the orthodox dogma (preached amongst others by the International Financial Institutions) and the heterodox practice (in several East Asian countries).

A transition towards more inward-looking strategies has, of course, a major implication: it biases growth towards countries with large domestic markets, and therefore against small economies. One major implication is that regional economic integration processes may have to play a more important role in the future, as sort of "expanded domestic markets", particularly in those regions where such processes are weakest: Sub-Saharan Africa and South Asia. This is an equally challenging issue for Latin America and Western Asia. A related implication is that developing countries should not forego such opportunities that exist for benefiting from trade -indeed by becoming scarcer, such opportunities will be, in a sense, all the more valuable.

This leads to a fourth set of issues that relate to how growth is going to be distributed among developing countries. In a sense, if we project current trends, East Asia and India (not South Asia as whole) are likely to be part of the dynamic poles of the new world economy. But this may leave many developing countries behind, particularly those with weak links with these dynamic poles, or competitors with them in global markets, or with patterns of growth that are only partly desirable (e.g., booming Chinese and commodity-led growth in Sub-Saharan Africa). The bias in recent international cooperation towards middle-income countries is also part of the problem. So, a major issue going forwards is to guarantee that we are not in the face of another major divergence in development, now not between industrial and developing countries, but among developing countries. Indeed, this has already been one part of the patterns of global development in recent decades, which Ocampo and Parra (2007) have characterized as a "dual divergence". This implies, in particular, serious thinking about the specific mechanism through which the most dynamic poles of the developing world are going to disseminate their growth to the developing world at large.

What all this implies, finally, is that the world we are looking forward at is going to be, in economic terms, much more dependent on the developing world than any we have observed in history. Never before has the call of the 2002 Monterrey Consensus (UN, 2002) to increase 
the participation of developing countries in global economic decision making been more important. Managing this world requires, therefore, major reform of global economic governance away from the industrial countries-centered institutions designed after the Second World War. The G-20 has been a step forward in this regard, but its representation is inadequate (in particular, medium and small-sized countries are entirely unrepresented, and there are major problems of representation of Sub-Saharan Africa, among others), it is still dominated in its specific dynamics by industrial countries and, particularly, lacks the legitimacy of a body that is elected as part of a process of global consensus-building. So, in this area, as in the specific mechanisms to manage such a world economy, there is a long road ahead. 



\section{REFERENCES}

ABDILDINA, ZHANAR, and JAIME JARAMILLO-VALLEJO (2005), "Streamlining conditionality in World Bank and International Monetary Fund-supported programs”, in Stefan Koeberle, Harold Bedoya, Peter Silarszky, and Gero Verheyen (eds.), Conditionality revisited, Washington D.C.: World Bank, pp. 8592.

AKYÜZ, YILMAZ (2010), “Global Economic Prospects: The Recession May be Over but What Next?”, Geneva: South Centre, Research Paper No. 26, March.

BAIROCH, PAUL (1993), Economics and World History: Myths and Paradoxes, Chicago: University of Chicago Press.

BARBOSA, NELSON (2010), “Counter-Cyclical Policies in Brazil: 2008-09”, Journal of Globalization and Development, Vol. 1, Issue 1, Article 13.

BERNANKE, BEN S. (2004), “The Great Moderation”, Remarks at the Meeting of the Eastern Economic Association, $\quad$ February 20, http://www.federalreserve.gov/Boarddocs/Speeches/2004/20040220/default.htm

BHINDA, BINDA and MATHEW MARTIN (2009), "Private Capital Flows to Low Income Countries: Dealing with Boom Bust”, London: Debt Relief International.

CAlVO, GUillermo (2010), "Policy in Times of Crisis: A View from the South”, Presentation for the MENA region retreat, World Bank, Washington D.C., February 23.

CPB NETHERLANDS (CPB Netherlands Bureau for Economic Policy Analysis) (2010), “International Cyclical Analysis: World Trade Monitor”, March 1, http://www.cpb.nl/eng/research/sector2/data/trademonitor.html

DERVIS, KEMAL (2008), “Fairness for Emerging Markets,” Washington Post, November 3, 2008.

DODD, RANDALL and SHARI SPIEGEL (2005), "Up from Sin: A Portfolio Approach to Financial Salvation," in Ariel Buira (ed.), The IMF and the World Bank at Sixty, London: Anthem Press, pp. 85-115.

ECLAC (UN Economic Commission for Latin America and the Caribbean) (2009), Preliminary Balance of the economies of Latin America and the Caribbean 2009, Santiago: ECLAC.

FFRENCH-DAVIS, RICARDO (2010), “Latin America: The Structural Fiscal Balance Policy in Chile: A Move Toward Counter-Cyclical Macroeconomics”, Journal of Globalization and Development, Vol. 1, Issue 1, Article 14.

GO, DELFIN and JOHN PAGE (eds.) (2008), Africa at a Turning Point?, Washington D.C.: World Bank.

GRIFFITH-JONES, STEPHANY and JOSÉ ANTONIO OCAMPO (2003), What Progress on International Financial Reform? Why So Limited?, Stockholm: Expert Group on Development Issues (EGDI) Swedish Ministry for Foreign Affairs, Almqvist \& Wiksell International, 2003.

and __ (2008), “Compensatory Financing for Shocks: What Changes are Needed?”, Paper Prepared for the United Nations Committee on Development Policy, April.

GRIFFITH-JONES and OCAMPO (2010), "La arquitectura financiera internacional a la luz de la crisis: Algunos logros y numeros desafios”, Document Prepared for Instituto Complutense de Estudios Internacionales, March.

ICC (International Chamber of Commerce), Banking Commission (2009), "ICC Trade Finance Survey: An Interim Report- Summer 2009”, September 4.

IIF (Institute of International Finance) (2009) “Capital Flows to Emerging Market Economies”, Washington D.C., January 27, www.iif.com

(2010), “Capital Flows to Emerging Market Economies”, Washington D.C., January 26, www.iif.com 
ILO (International Labor Organization) (2009), World of Work Report 2009: The Global Jobs Crisis and Beyond, Geneva: International Institute for Labor Studies.

(2010), Global Employment Trends, Geneva, January, available at: http://www.ilo.org/empelm/what/pubs/lang--en/docName--WCMS_120471/index.htm

IMF (International Monetary Fund) (2002), “Guidelines on Conditionality”, Prepared by the Legal and Policy Development and Review Departments, Washington D.C., September 25, http://www.imf.org/External/np/pdr/cond/2002/eng/guid/092302.pdf

(2005), The Managing Director's Report On The Fund's Medium-Term Strategy, Document Presented to the International Monetary and Financial Committee, Washington, DC, September 15.

(2009a), World Economic Outlook, Washington D.C., October.

(2009b), Global Financial Stability Report, Washington D.C., October.

(2009c), Regional Economic Outlook: Sub-Saharan Africa: Weathering the Storm, Washington D.C., October.

(2009d), “IMF implements major lending policy improvements”, Washington, DC, March, http://www.imf.org/external/np/pdr/fac/2009/032409.htm

(2009e), “IMF Reforms Financial Facilities for Low-Income Countries”, Washington, DC, July, http://www.imf.org/external/np/sec/pn/2009/pn0994.htm

(2009f), "Concessionality and the Design of Debt Limits in IMF-Supported Programs in Low-Income Countries”, Washington, DC, December, http://www.imf.org/external/np/pdr/conc/

(2010a), World Economic Outlook Update, Washington D.C., January 26, http://www.imf.org/external/index.htm

(2010b), Global Financial Stability Report Market Update, Washington D.C., January 26, http://www.imf.org/external/index.htm

IMF-IEO (Independent Evaluation Office) (2008), An IEO Evaluation of Structural Conditionality in IMFSupported Programs, January, http://www.ieo-imf.org/eval/complete/eval_01032008.html

INTER-AMERICAN DEVELOPMENT BANK (2008), All that Glitters May Not be Gold: Assessing Latin America's Recent Macroeconomic Performance, Washington D.C., April.

Multilateral Investment Fund (2010), Remittances to Latin America and the Caribbean during 2009: The Effects of the Global Financial Crisis, Washington D.C., http://www.iadb.org/mif/subtopic.cfm?language=English\&SUBTOPIC=REMS\&TOPIC=

JPMORGAN (2008), “Determinants of Mexico’s remittances from the U.S.”, Global Data Watch, October 17

(2009-10), Global Data Watch, several issues.

KASEKENDE, LOUIS, ZUZANA BRIXOVA and LEONCE NDIKUMANA (2010), “Africa: Africa’s CounterCyclical Policy Responses to the Crisis”, Journal of Globalization and Development, Vol. I, Issue 1, Article 16.

KILLICK, TONY (2005), “Did conditionality streamlining succeed?”, in Stefan Koeberle, Harold Bedoya, Peter Silarszky, and Gero Verheyen (eds.), Conditionality revisited, Washington D.C.: World Bank, pp. 9396.

NOMAN, AKBAR, JOSEPH STIGLITZ, KWESI BOTCHWEY and HAROLD STEIN (eds) (2010), Good Growth and Governance in Africa: Rethinking Development Strategies (OUP, forthcoming)

O’ROURKE, KEVIN H. (2009), “Government Policies and the Collapse in Trade during the Great Depression”, November 27, http://www.voxeu.org/index.php?q=node/4267

OCAMPO, JOSÉ ANTONIO (2009), “Latin America and the Global Financial Crisis”, Cambridge Journal of Economics, Vol. 33, No. 4, July. 
(2010), "Reforming the Global Reserve System”, in Stephany Griffith-Jones, José Antonio Ocampo and Joseph E. Stiglitz (eds.), Time for a Visible Hand: Lessons from the 2008 World Financial Crisis, New York, Oxford University Press.

and Stephany Griffith-Jones (2008), “A Counter-cyclical Framework for a Development-friendly International Financial Architecture”, in José María Fanelli (ed.), Macroeconomic Volatility, Institutions and Financial Architecture: The Developing World Experience, Houndmills: Palgrave/Macmillan.

and Mariángela Parra (2003), “The Terms of Trade for Commodities in the Twentieth Century”, CEPAL Review, No. 79, April.

and __ (2007), “The Dual Divergence: Growth Successes and Collapses in the Developing World Since 1980”, in Ricardo Ffrench-Davis and José Luis Machinea (eds.), Economic Growth with Equity: Challenges for Latin America, Houndmills, Hampshire: Palgrave Macmillan and ECLAC.

, Codrina Rada and Lance Taylor (2009), Growth and Policy in Developing Countries: A Structuralist Approach, New York, Columbia University Press.

ÖZATAY, FATIH (2010), "Europe: Countercyclical Policies in Light of the Global Financial Crisis: Case of Turkey”, Journal of Globalization and Development, Vol. 1, Issue 1, Article 18.

RATHA, DILIP, SANKET MOHAPATRA and ZHIMEI XU (2008), “Outlook for Remittance Flows 20082010: Growth expected to moderate significantly, but flows to remain resilient”, Migration and Development Brief No. 8, World Bank, Development Prospects Group, Migration and Remittances Team, November 11.

and ANI SILWAL1 (2009), "Migration and Remittance Trends: A better-than-expected outcome so far, but significant risks ahead”, Migration and Development Brief No. 11, World Bank, Development Prospects Group, Migration and Remittances Team, November 3.

REINHART, CARMEN M. and KENNETH ROGOFF (2009), This Time is Different: Eight Centuries of Financial Folly, Princeton: Princeton University Press.

ROUBINI, NOURIEL (2009), “The Mother of All Carry Trades Faces and Inevitable Bust”, Financial Times, November 2.

STIGLITZ, JOSEPH (2002), Globalization and Its Discontents, New York: W.W. Norton.

(2010)), Free Fall: America, Free Markets, and the Sinking of the World Economy, New York and London: W.W. Norton.

SUBRAMANIAN, ARVIND (2009), “Coordinated Capital Controls: A Further Elaboration”, http://baselinescenario.com/2009/11/29/coordinated-capital-controls-a-further-elaboration/

TE VELDE, DIRK and ISABELLA MASSA (2009), "Donor Responses to Global Financial Crisis: A Stock Take”, Global Financial Crisis Discussion Series, ODI Working Paper No. 11, London, December, http://www.odi.org.uk/resources/details.asp?id=4630\&title=global-financial-crisis-donor-responsesstock-take

UN (United Nations) (2002), The Monterrey Consensus, International Conference on Financing for Development, Monterrey, México, March, available at: http://www.un.org/esa/ffd/.

(2009a), World Economic Situation and Prospects 2009, New York, January.

(2009b), MDG Gap Task Force Report 2009: Strengthening the Global Partnership for Development in a Time of Crisis, New York, July.

(2009c), Report of the Commission of Experts of the UN General Assembly on Reforms of the International Monetary and Financial System [Stiglitz Commission], New York, September. http://www.un.org/ga/econcrisissummit/docs/FinalReport_CoE.pdf

(2010a), World Economic Situation and Prospects 2009, New York: United Nations, January.

(2010b), World Economic Vulverability Monitor No.3, February.

UNCTAD (United Nations Conference on Trade and Development) (2009), The Global Economic Crisis: Systemic Failures and Multilateral Remedies, Geneva. 
UYGUR, ERCAN (2010), “The Global Crisis and the Turkish Economy”, TWN Global Economic Series No. 21, Penang: Third World Network.

VON BRAUN, JOACHIM (2007), “The World Food Situation: New Driving Forces and Required Actions”, Food Policy Report, Washington, D.C., International Food Policy Research Institute, December.

MARK WEISBROT, MARK, REBECCA RAY, JAKE JOHNSTON, JOSE ANTONIO CORDERO and JUAN ANTONIO MONTECINO (2009), IMF-Supported Macroeconomic Policies and the World Recession: A Look at Forty-One Borrowing Countries, Washington D.C.: Center for Economic and Policy Research, October, http://www.cepr.net/index.php/publications/reports/imf-supported-macroeconomicpolicies-and-the-world-recession/

WORLD BANK (2009a), Global Economic Prospects 2009: Commodities at the Crossroads, Washington D.C. WORLD BANK (2009b), Global Development Finance: Charting a Global Recovery, Washington D.C.

WORLD BANK (2010), Global Economic Prospects: Crisis, Finance and Growth, Washington D.C.

YU, YONGDIN (2010), “Asia: China’s Policy Response to the Global Financial Crisis”, Journal of Globalization and Development, Vol. 1, Issue 1, Article 12. 


\section{Table A.1: Examples of Structural Conditionality by Type of Condition}

for PRGF Program, (2008-09)

\begin{tabular}{|c|c|c|c|}
\hline Country Name & $\begin{array}{l}\text { Type of } \\
\text { Structural } \\
\text { Condition }\end{array}$ & Economic Description & Description \\
\hline BURUNDI & SPC & 11.4. Anti-corruption legislation/policy & $\begin{array}{l}\text { In accordance with the laws of Burundi, the FBu } 6 \text { billion and the deeds for } 25 \text { properties belonging to Interpetrol } \\
\text { that have been placed under seal will remain in place until a court decision has been reached on the Interpetrol } \\
\text { case. }\end{array}$ \\
\hline ZAMBIA & SPC & $\begin{array}{l}\text { 11.1. Private sector legal and regulatory environment reform } \\
\text { (non financial sector) }\end{array}$ & $\begin{array}{l}\text { Submit to Cabinet a policy for the electricity sector with specific startegies to (i) gradually adjust electricity tariffs } \\
\text { to the cost of service; (ii) attract private investment and competition in the sector; (iii) increase the operational } \\
\text { efficiency of ZESCO; and (iv) ensure that ZESCO has sufficient resources to implement the planned rehabilitation } \\
\text { and new generation projects. }\end{array}$ \\
\hline MALI & SPC & 6.2. Restructuring and privatization of financial institutions & $\begin{array}{l}\text { Submission to the Regional Banking Commission of a restructuring plan for BHM raising capital and liquidity ratios } \\
\text { to WAEMU prudential norms. }\end{array}$ \\
\hline NIGER & SPC & 6.1. Financial sector legal reforms, regulation, and supenision & $\begin{array}{l}\text { Adoption of the decree establishing the terms for repayment of savings deposits frozen by the former National Post } \\
\text { and Savings Office (ONPE). }\end{array}$ \\
\hline CONGO, REPUBLIC OF & SPC & $\begin{array}{l}\text { 5.2. Privatization, public enterprise reform and restructuring, } \\
\text { other than pricing }\end{array}$ & $\begin{array}{l}\text { Adopt a comprehensive action plan with a timetable to address institutional and procedural deficiencies in the } \\
\text { commercialization of Congolese oil, in line with best international practices. }\end{array}$ \\
\hline TOGO & SPC & 3. Civil service and public employment reforms, and wages & Make operational a new Treasury structure based on WAEMU directives. \\
\hline DJIBOUTI & SPC & 2.1. Central bank operations and reforms & Strengthen monetary control by introducing reserve requirements with respect to deposits. \\
\hline CONGO, REPUBLIC OF & SPC & 1.8. Budget preparation (e.g., submission or approval) & $\begin{array}{l}\text { Prepare the } 2009 \text { budget consistent with the PRGF program, and using the economic, functional, and } \\
\text { administrative classifications. }\end{array}$ \\
\hline SAO TOME AND PRINCIPE & SPC & 1.6. Expenditure auditing, accounting, and financial controls & Public Financial Management - Purchase and install IT equipment related to the SAFINHO. \\
\hline ARMENIA & SPC & 1.5. Debt Management & $\begin{array}{l}\text { Strengthen domestic debt market by signing an agreement between the Ministry of Finance (MoF) and Central } \\
\text { Bank (CBA) on the coordination of government securities auctions, including: (ii) a commitment to avoid using cut- } \\
\text { off yields at Treasury auctions, except to reject clearly speculative bids that lie outside the normal range of bidding. }\end{array}$ \\
\hline NIGER & SPC & 1.1. Revenue measures, excluding trade policy & $\begin{array}{l}\text { Reduction of the rate of profit tax from } 35 \text { to } 30 \text { percent, applicable to profits reported for FY } 2009 \text { and for following } \\
\text { years. }\end{array}$ \\
\hline COMOROS & SB & 11.3. PRSP development and implementation & Government approval of the final PRSP. \\
\hline CONGO, REPUBLIC OF & SB & $\begin{array}{l}\text { 11.2. Natural resource and agricultural policies (excl. public } \\
\text { enterprises and pricing) }\end{array}$ & $\begin{array}{l}\text { Finalize the strategic study of the oil-sector-assisted by Congo's development partners--which will include a critical } \\
\text { assessment of the institutions and enterprises, including CORAF (state-owned oil refinery). }\end{array}$ \\
\hline DJIBOUTI & SB & $\begin{array}{l}\text { 11.1. Private sector legal and regulatory environment reform } \\
\text { (non financial sector) }\end{array}$ & Submit the new Commercial Code, prepared with the assistance of the European Union, to the National Assembly. \\
\hline SAO TOME AND PRINCIPE & SB & 6.1. Financial sector legal reforms, regulation, and supenision & Put in place intervention and closure processes for the banking system. \\
\hline COMOROS & SB & 5.3. Price controls and marketing restrictions & Maintaining a flexible petroleum price-fixing mechanism. \\
\hline MALI & SB & $\begin{array}{l}\text { 5.2. Privatization, public enterprise reform and restructuring, } \\
\text { other than pricing }\end{array}$ & Adoption by the Council of Ministers of the reform master plan and of a development contract at the Niger Authority \\
\hline COMOROS & SB & 3. Civil service and public employment reforms, and wages & $\begin{array}{l}\text { Submitting a draft law to parliament that sets the organic frameworks for the island ministries in line with the } \\
\text { recommendations of the High Authority for the Public Administration (Haute Autorite de la Fonction Publique). }\end{array}$ \\
\hline TAJIKISTAN & SB & 2.2. Central bank auditing, transparency, and financial controls & $\begin{array}{l}\text { Conduct quarterly internal audits of the National Bank of Tajikistan's financial statement to be discussed by the } \\
\text { National Bank of Tajikistan's Board. }\end{array}$ \\
\hline ZAMBIA & SB & 2.1. Central bank operations and reforms & Bank of Zambia will introduce a new standing overnight lending facility. \\
\hline COTE D'IVOIRE & SB & 1.8. Budget preparation (e.g., submission or approval) & $\begin{array}{l}\text { Adoption by the government of the } 2010 \text { budget with budgetization and fiscalization of all quasi-fiscal levies for } \\
\text { investment in the cocoa/coffee sector. }\end{array}$ \\
\hline NIGER & SB & 1.7. Fiscal transparency (publication, parliamentary oversight) & $\begin{array}{l}\text { Publish data on budget outturn for } 2008 \text {, including for the unified list of priority expenditures and the President's } \\
\text { Special Program. }\end{array}$ \\
\hline GHANA & SB & 1.6. Expenditure auditing, accounting, and financial controls & $\begin{array}{l}\text { Review of the effectiveness of the existing budget information management system, and decision on whether it } \\
\text { should be modernized or replaced. }\end{array}$ \\
\hline COMOROS & SB & 1.5. Debt Management & Government approval of a strategy for clearance of domestic payment arrears. \\
\hline DJIBOUTI & SB & 1.1. Revenue measures, excluding trade policy & $\begin{array}{l}\text { Revise the Investment Code to streamline tax exemptions (duration of exemptions, list of tax benefits) and } \\
\text { strengthen the procedures and resources for monitoring exempt projects. }\end{array}$ \\
\hline TOGO & PA & 6.2. Restructuring and privatization of financial institutions & $\begin{array}{l}\text { Change management and oversight of BTCI based on terms of reference prepared in consultation with the WAEMU } \\
\text { Banking Commission. }\end{array}$ \\
\hline COMOROS & PA & $\begin{array}{l}\text { 5.2. Privatization, public enterprise reform and restructuring, } \\
\text { other than pricing }\end{array}$ & Formal government request for AfDB assistance in the reform of the electricity parastatal(MA-MWE). \\
\hline COTE D'IVOIRE & PA & 5.1. Public enterprise pricing and subsidies & Implementation of automatic petroleum pricing mechanism. \\
\hline GHANA & PA & 5.1. Public enterprise pricing and subsidies & Reinstatement of automatic bi-weekly price adjustments for petroleum products. \\
\hline TAJIKISTAN & PA & 2.2. Central bank auditing, transparency, and financial controls & $\begin{array}{l}\text { Appoint an external auditor to conduct the audit of the National Bank of Tajikistan's financial statements in } \\
\text { accordance with international standards (ISAs) for the fiscal year ending April 30, 2009. }\end{array}$ \\
\hline BURUNDI & PA & 2.1. Central bank operations and reforms & $\begin{array}{l}\text { Submission to the National Assembly of the draft Law on the Charter of the BRB together with the January } 2008 \\
\text { recommendations by Fund staff on improvement of the law. }\end{array}$ \\
\hline COTE D'IVOIRE & PA & 1.8. Budget preparation (e.g., submission or approval) & Adoption by the government of a supplementary budget for 2009 in line with program objectives. \\
\hline COMOROS & PA & 1.5. Debt Management & $\begin{array}{l}\text { Agreements with relevant creditors on rescheduling of external payment arrears and deferment of } 2009 \text { debt } \\
\text { payment to non -IMF/WB/AfDB creditors. }\end{array}$ \\
\hline GHANA & PA & 1.4. Combined expenditure and revenue measures & Adoption of budget to limit fiscal deficit to 9.4 percent of GDP in 2009. \\
\hline MALI & PA & 1.1. Revenue measures, excluding trade policy & Reach floor levels for the taxation of petroleum products \\
\hline LIBERIA & SPC & 6.1. Financial sector legal reforms, regulation, and supenision & $\begin{array}{l}\text { Establish system of off-site inspection by requiring quarterly submission of prescribed data by all banks, and } \\
\text { submit the first written reports to the Banking Compliance Committee. }\end{array}$ \\
\hline
\end{tabular}

Source: IMF, Monitoring of Fund Arrangements (MONA) database, own selection 


\begin{tabular}{|c|c|c|c|}
\hline Country Name & $\begin{array}{l}\text { Type of } \\
\text { Structural } \\
\text { Condition }\end{array}$ & Economic Description & Description \\
\hline UKRAINE & SPC & 8. International trade policy, excluding customs reforms & Prohibition on the imposition or intensification of import restrictions for balance of payments reasons. \\
\hline UKRAINE & SPC & 7. Exchange systems and restrictions (current and capital) & Prohibition on the conclusion of bilateral payments agreements that are inconsistent with Article VIII. \\
\hline UKRAINE & SPC & 6.2. Restructuring and privatization of financial institutions & $\begin{array}{l}\text { Resolve all problem banks by end June } 2009 \text {, so that viable banks meet the regulatory minimum capital } \\
\text { and nonviable banks are liquidated. }\end{array}$ \\
\hline GEORGIA & SPC & 6.1. Financial sector legal reforms, regulation, and supervision & $\begin{array}{l}\text { The NGB, the FSA, and the government to develop a financial stability plan that will contain policy actions } \\
\text { to respond to potential situations of stress by defining the roles and responsibilities of the different } \\
\text { playersthe NBG, the FSA and the governmentunder each circumstance. }\end{array}$ \\
\hline HONDURAS & SPC & 5.1. Public enterprise pricing and subsidies & Implementation of a tariff policy in the electricity sector to ensure operational cost recovery. \\
\hline LATVIA & SB & 9. Labor markets, excluding public sector employment & Establish a committe to promote wage restraint \\
\hline PAKISTAN & SB & 7. Exchange systems and restrictions (current and capital) & The State Bank of Pakistan's provision of foreign exchange for furnace oil will be eliminated. \\
\hline COSTA RICA & SB & 6.1. Financial sector legal reforms, regulation, and supervision & Submission to the Legislative Assembly of a draft law to create a limited deposit guarantee scheme. \\
\hline UKRAINE & SB & 6.1. Financial sector legal reforms, regulation, and supervision & $\begin{array}{l}\text { Enact necessary amendments to legislation to include definition and disclosure of ultimate controllers of } \\
\text { banks. }\end{array}$ \\
\hline ARMENIA & SB & 6. Financial sector & Start offering repo operations with a maturity of at least three months. \\
\hline UKRAINE & SB & $\begin{array}{l}\text { 5.2. Privatization, public enterprise reform and restructuring, } \\
\text { other than pricing }\end{array}$ & $\begin{array}{l}\text { Initiate the implementation of the reform and restructuring strategy for Naftogaz, including a mechanism for } \\
\text { transparent financing of gas transit modernization needs, in accordance with the principles of the Brussels } \\
\text { declaration. }\end{array}$ \\
\hline PAKISTAN & SB & 5.1. Public enterprise pricing and subsidies & $\begin{array}{l}\text { In close collaboration with the World Bank, the government (will finalize the schedule for further electricity } \\
\text { tariff adjustments during 2008/09--sb with 12/31/08 test date) with a view to eliminating tariff differential } \\
\text { subsidies. }\end{array}$ \\
\hline ARMENIA & SB & $\begin{array}{l}\text { 4.2. Other social sector reforms (e.g., social safety nets, } \\
\text { health and education) }\end{array}$ & $\begin{array}{l}\text { In close collaboration with the World Bank, develop a strategy to further strengthen the targeting of social } \\
\text { safety nets. }\end{array}$ \\
\hline PAKISTAN & SB & $\begin{array}{l}\text { 4.2. Other social sector reforms (e.g., social safety nets, } \\
\text { health and education) }\end{array}$ & $\begin{array}{l}\text { In close collaboration with the World Bank, the government will develop a strategy and a time-bound action } \\
\text { plan for the adoption of specific measures to strengthen the social safety net and improve targeting to the } \\
\text { poor. }\end{array}$ \\
\hline ROMANIA & SB & 4.1. Pension reforms & Passage of revised pension legislation \\
\hline SERBIA,REPUBLIC OF & SB & 3. Civil service and public employment reforms, and wages & $\begin{array}{l}\text { Adopt business plans of state enterprises that conform to general government wage and employment policy } \\
\text { in } 2009 \text { and ensure profit transfers to the state. }\end{array}$ \\
\hline SEYCHELLES & SB & 2.2. Central bank auditing, transparency, and financial controls & Central Bank of Seychelles (CBS) to publish commercial bank supervision report. \\
\hline UKRAINE & SB & 2.1. Central bank operations and reforms & $\begin{array}{l}\text { Ensure de jure and de facto independence of the NBU. Enact legislation to strengthen the overall } \\
\text { governance structure of the NBU; in particular, reform the NBU council, transforming it into a narrower } \\
\text { technical body and revise the NBU Law as needed to address all safeguards-related weaknesses, as noted } \\
\text { by the recent safeguards assessment. }\end{array}$ \\
\hline $\begin{array}{l}\text { BOSNIA AND } \\
\text { HERZEGOVINA }\end{array}$ & SB & 1.8. Budget preparation (e.g., submission or approval) & Approve the rebalanced budgets by the Entity Parliaments. \\
\hline ICELAND & SB & 1.7. Fiscal transparency (publication, parliamentary oversight) & Improve the medium term fiscal framework. \\
\hline SERBIA,REPUBLIC OF & SB & 1.6. Expenditure auditing, accounting, and financial controls & $\begin{array}{l}\text { MoF to prepare a three-month rolling cash flow plan for the Republican budget consistent with the annual } \\
\text { budget targets. }\end{array}$ \\
\hline LATVIA & SB & 1.5. Debt Management & Develop a comprehensive debt restructuring strategy. \\
\hline SEYCHELLES & SB & 1.5. Debt Management & $\begin{array}{l}\text { Submit to parliament a Public Debt Law, defining a legal framework for public debt management, and } \\
\text { specifying the roles and responsibilities of the bodies engaged in contracting and managing public debt. }\end{array}$ \\
\hline ROMANIA & SB & 1.4. Combined expenditure and revenue measures & Ratification by parliament of fiscal measures equivalent to 1.1 percent of GDP. \\
\hline MONGOLIA & SB & 1.3. Expenditure measures, including arrears clearance & $\begin{array}{l}\text { The submission to parliament of Fiscal Responsibility Law consistent with recommendations of Fund } \\
\text { technical assistance. }\end{array}$ \\
\hline PAKISTAN & SB & 1.1. Revenue measures, excluding trade policy & Submission of the VAT to Parliament. \\
\hline SEYCHELLES & SB & 1.1. Revenue measures, excluding trade policy & Adopt a tax policy reform strategy with FAD TA. \\
\hline UKRAINE & PA & 7. Exchange systems and restrictions (current and capital) & $\begin{array}{l}\text { Improve the functioning of the foreign exchange market, including by amending NBU regulation } 108 \text { to lift } \\
\text { the ban on foreign exchange forward and spot transactions. }\end{array}$ \\
\hline ICELAND & PA & 6.2. Restructuring and privatization of financial institutions & $\begin{array}{l}\text { Establish a committee comprising representatives from the Prime Ministers Office, the Financial } \\
\text { Supervisory Authority, the Central Bank of Iceland, the Ministry of Finance and the Ministry of commerce } \\
\text { to coordinate policy input and will be chaired by the expert in charge of the bank restructuring process. }\end{array}$ \\
\hline UKRAINE & PA & 6.2. Restructuring and privatization of financial institutions & Finalize the resolution of the Prominvest Bank. \\
\hline LATVIA & PA & 6.1. Financial sector legal reforms, regulation, and supervision & $\begin{array}{l}\text { The management of Parex Bank to develop a resolution plan considering all options for the bank, and } \\
\text { submit it to the FCMC }\end{array}$ \\
\hline UKRAINE & PA & 5.1. Public enterprise pricing and subsidies & $\begin{array}{l}\text { Announce an increase in the price of natural gas paid by households (effective September } 1 \text { ) and utility } \\
\text { companies (effective October } 1 \text { ) by } 20 \text { percent to bring these tariffs at } 31 \text { and } 43 \text { percent of import prices, } \\
\text { respectively, and announce a schedule of } 20 \text { percent quarterly price increases for households and utility } \\
\text { companies starting in January 2010. Introduce mechanisms to enforce payment discipline of utility } \\
\text { companies and households. }\end{array}$ \\
\hline LATVIA & PA & 3. Civil service and public employment reforms, and wages & $\begin{array}{l}\text { The government will sign a protocol that stipulates a } 15 \text { percent reduction in local government employees' } \\
\text { compensation. }\end{array}$ \\
\hline UKRAINE & PA & 2.2. Central bank auditing, transparency, and financial controls & $\begin{array}{l}\text { Announce a tender for a Special Audit of NBU refinancing and foreign exchange operations in } 2008 \text {, to be } \\
\text { executed by a qualified international audit firm, on the basis of a terms of reference agreed with IMF staff. }\end{array}$ \\
\hline SRI LANKA & PA & 2. Central Bank & Harmonize the penal rate for commercial bank borrowing from the CBSL with the reverse repo rate. \\
\hline BELARUS & PA & 1.8. Budget preparati & Legal approval of a central government budget with a zero deficit by a Presidential decree. \\
\hline BELARUS & PA & 1.6. Expenditure auditing, accounting, and financial controls & Eliminate additional deposit transfers from the central and local governments to commercial banks. \\
\hline PAKISTAN & PA & 1.5. Debt Management & $\begin{array}{l}\text { The State Bank of Pakistan (SBP) and the government agreed on quarterly volumes of treasury bills to be } \\
\text { issued and published the expected volume for the remainder of the second quarter of } 2008 / 09 \text {. }\end{array}$ \\
\hline UKRAINE & $\mathrm{PA}$ & 1.4. Combined expenditure and revenue measures & Adopt measures reducing the general government deficit by at least 1 percent of GDP in 2009. \\
\hline $\begin{array}{l}\text { BOSNIA AND } \\
\text { HERZEGOVINA }\end{array}$ & PA & 1. General government & Adopt the Global Framework by the Fiscal Council \\
\hline
\end{tabular}

Source: IMF, Monitoring of Fund Arrangements (MONA) database, own selection 